FINAL REPORT

\title{
DESTRUCTION TECHNOLOGY DEMONSTRATION FOR ORGANICS IN TRANSURANIC WASTE
}

\author{
Work Performed Under Contract: \\ DE-AC26-01NT41200 \\ Submitted By: \\ GENERAL ATOMICS \\ 3550 GENERAL ATOMICS COURT \\ SAN DIEGO, CA 92121-1194 \\ Program Manager: \\ Mike Spritzer \\ Phone No: 858/455-2337 \\ FAX No: 858/455-4111 \\ E-mail: Michael.Spritzer@gat.com \\ Project Manager/P.I.: \\ Mike Spritzer \\ Phone No: 858/455-2337 \\ FAX No: 858/455-4111 \\ E-mail: Michael.Spritzer@gat.com
}

Submitted To:

U.S. Department of Energy

Federal Energy Technology Center

COR: Vijendra P. Kothari

E-mail: vijendra.kothari@netl.doe.gov

FEBRUARY 2003 


\begin{abstract}
General Atomics (GA) has recently completed a Phase I program for the development of a twostep alternative to incineration for the destruction of organics in transuranic wastes at the Savannah River Site. This process is known as thermal desorption-supercritical water oxidation, or TD-SCWO. The GA TD process uses heat to volatilize and transport organics from the waste material for subsequent treatment by SCWO. SCWO oxidizes organics in a steam medium at elevated temperatures and pressures in a manner that achieves excellent destruction efficiencies and compliance with all environmental requirements without the need for complex pollution-abatement equipment. This application of TD-SCWO is focused on a fullscale batch process for 55-gallon drums of mixed transuranic waste at the Savannah River Site.

The Phase I reduced-scale test results show that the process operates as intended on surrogate waste matrices chosen to be representative of Savannah River Site transuranic mixed wastes. It provides a high degree of hydrogen removal and full containment of the radionuclide surrogate, with minimal requirements for pre-treatment and post-treatment. Other test objectives were to verify that the process produces no dioxins or furans, and meets all applicable regulatory criteria for retention of toxic metals, particulate, and criteria pollutants, while meeting WIPP/WAC and TRUPACT-II requirements. Thermal desorption of surrogate SRS mixed wastes at 500 psi and $1000^{\circ} \mathrm{F}$ met all tested requirements for WIPP/WAC and TRUPACT-II. SCWO of the desorbed surrogate organic materials at $500 \mathrm{psi}$ and $1500^{\circ} \mathrm{F}$ also appears to meet all requirements for a nonincineration alternative, although $>99.99 \%$ DRE for chlorinated solvents has not yet been demonstrated.
\end{abstract}




\section{TABLE OF CONTENTS}

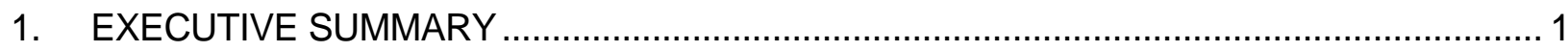

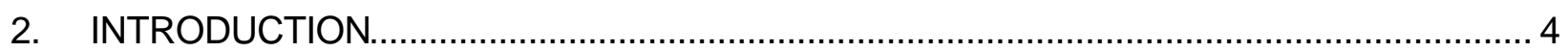

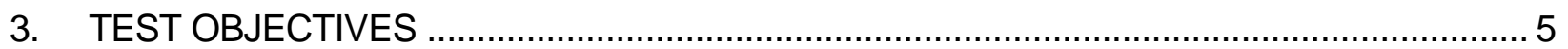

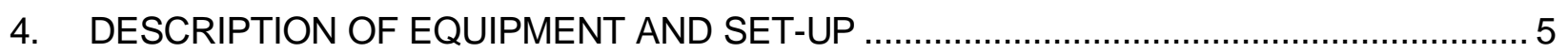

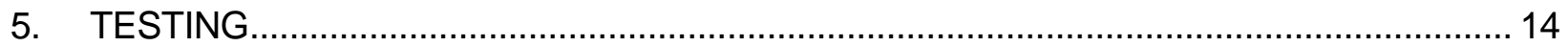

5.1. Thermal Desorber Tests ................................................................................ 14

5.2. Thermal Desorber-SCWO Integration and Optimization Tests................................ 14

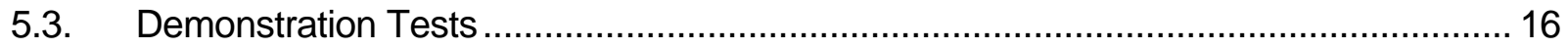

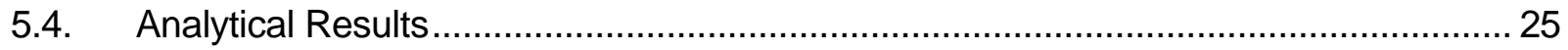

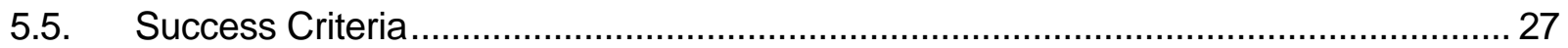

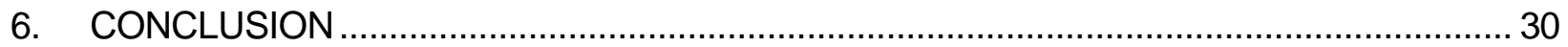

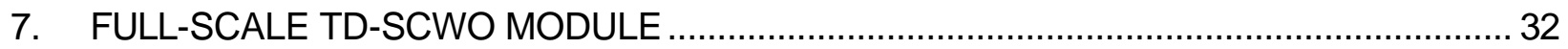

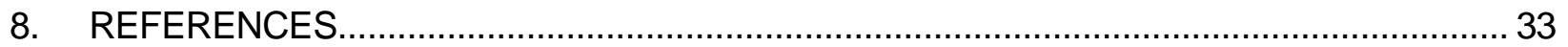

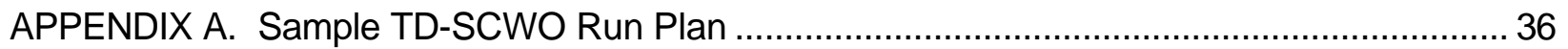

APPENDIX B. AirKinetics Report on Gas Effluent Analyses ...................................................... 42 


\section{LIST OF FIGURES}

Figure 1. Process Flow Diagram (PFD) for GA TD-SCWO pilot plant...................................... 6

Figure 2. Pilot plant thermal desorber. Dimensions in inches................................................. 8

Figure 3. Pilot plant SCWO reactor. Dimensions in inches................................................. 9

Figure 4. Pilot plant TD canister and 55-gal drum. .......................................................... 10

Figure 5. Pilot plant thermal desorber. ………………........................................................ 11

Figure 6. Pilot plant SCWO reactor skid........................................................................... 11

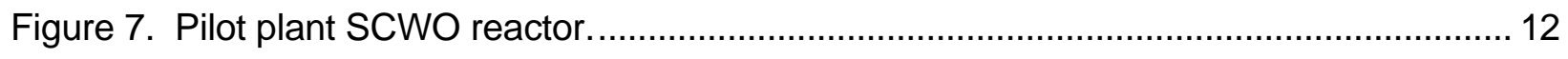

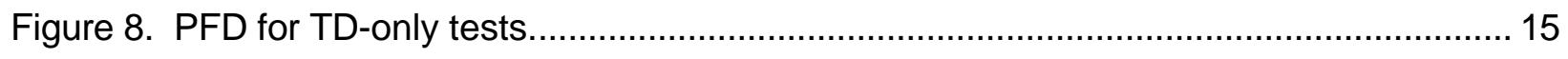

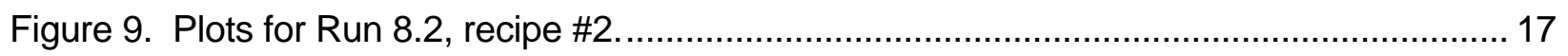

Figure 10. Plots for Run 10.1, recipe \#1 ..................................................................... 19

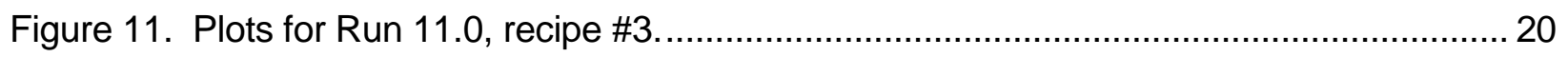

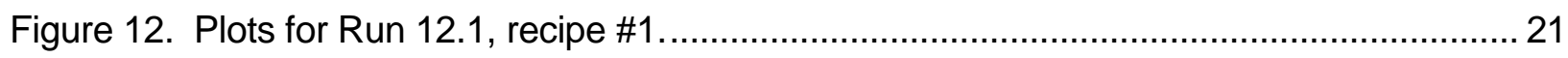

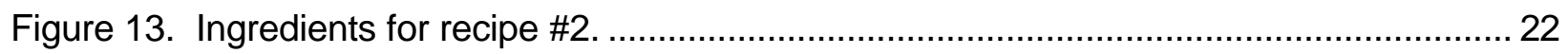

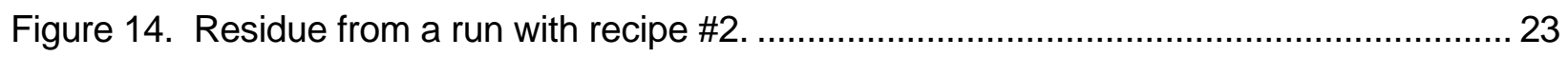

Figure 15. Comparison of materials entering and leaving the SCWO unit................................. 24

Figure 16. Process flow diagram for a full- scale TD-SCWO module......................................... 34

Figure 17. Architectural rendering of a full- scale TD-SCWO facility .......................................... 35

\section{LIST OF TABLES}

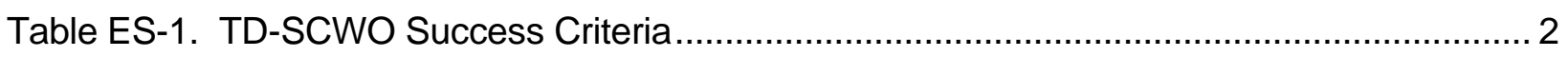

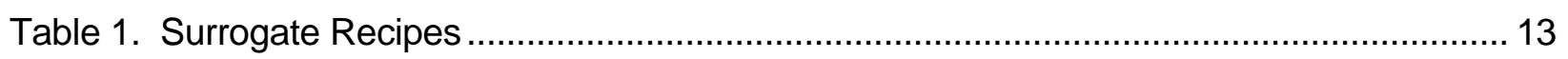

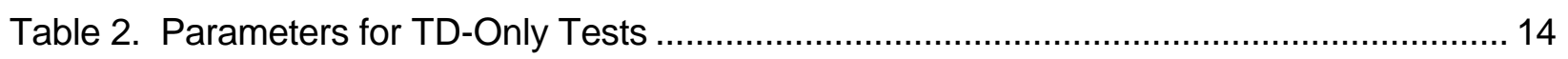

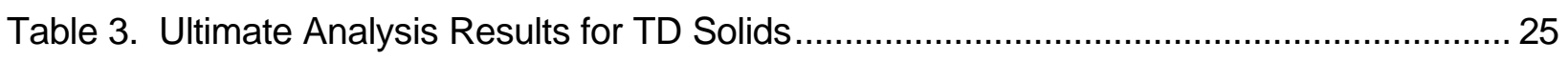

Table 4. Cerium Analysis Results for TD Solids and Condensate ......................................... 26

Table 5. Analytical Results for SCWO Liquid Effluent ......................................................... 26

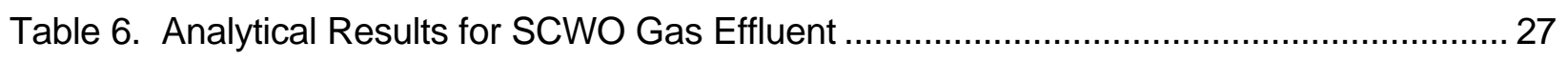

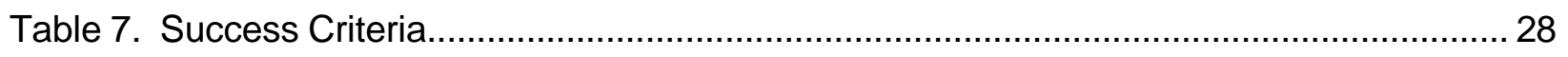

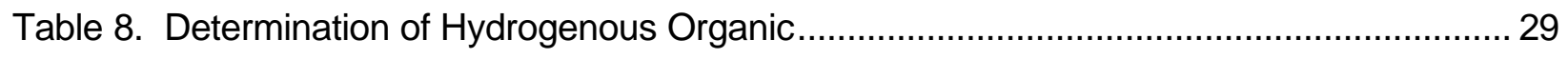

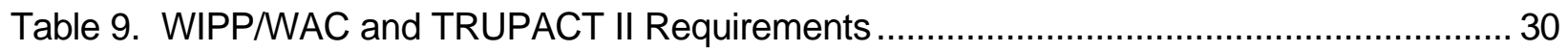

Table 10. Comparison of TD-SCWO Pilot Plant and Full-Scale Module ..................................... 32 


\section{Acronyms and Abbreviations}

\begin{tabular}{|l|l|}
\hline As & Arsenic \\
\hline $\mathrm{Be}$ & Beryllium \\
\hline $\mathrm{Btu}$ & British thermal unit \\
\hline $\mathrm{C}$ & Carbon \\
\hline $\mathrm{CCI_{4 }}$ & Carbon tetrachloride \\
\hline $\mathrm{C}_{2} \mathrm{Cl}_{4}$ & Perchloroethylene or tetrachloroethylene \\
\hline $\mathrm{Cd}$ & Cadmium \\
\hline $\mathrm{Ce}$ & Cerium \\
\hline $\mathrm{CeO}{ }_{2}$ & Cerium oxide \\
\hline $\mathrm{CO}$ & Carbon monoxide \\
\hline $\mathrm{CO} \mathrm{O}_{2}$ & Carbon dioxide \\
\hline $\mathrm{Cr}$ & Chromium \\
\hline $\mathrm{CW}$ & Cooling water \\
\hline $\mathrm{DI}$ & Deionized water \\
\hline $\mathrm{DRE}$ & Destruction and removal efficiency \\
\hline $\mathrm{dscf}$ & Dry standard cubic feet \\
\hline $\mathrm{dscm}$ & Dry standard cubic meter \\
\hline $\mathrm{F}$ & Flowmeter \\
\hline $\mathrm{ft}$ & Feet \\
\hline $\mathrm{g}$ & Grams \\
\hline $\mathrm{GA}$ & General Atomics \\
\hline $\mathrm{gal}$ & Gallons \\
\hline $\mathrm{GC} / \mathrm{MS}$ & Gas chromatography/mass spectrometry \\
\hline $\mathrm{GLS}$ & Gas-liquid separator \\
\hline $\mathrm{H}$ & Hydrogen \\
\hline $\mathrm{HC}$ & Hydrocarbons \\
\hline $\mathrm{HCl}$ & Hydrochloric acid \\
\hline $\mathrm{HEPA}$ & High-efficiency particulate \\
\hline $\mathrm{Hg}$ & Mercury \\
\hline $\mathrm{H}_{2} \mathrm{O}$ & Water \\
\hline $\mathrm{Hr}$ & Hours \\
\hline $\mathrm{H}_{2} \mathrm{SO} \mathrm{O}_{4}$ & Sulfuric acid \\
\hline $\mathrm{ID}$ & Inner diameter \\
\hline $\mathrm{in}$ & Inches \\
\hline $\mathrm{IPA}$ & Isopropyl alcohol \\
\hline $\mathrm{kg}$ & Kilogram \\
\hline $\mathrm{L}$ & Liters \\
\hline $\mathrm{Ib}$ & Pounds \\
\hline $\mathrm{LCC}$ & Life cycle cost \\
\hline $\mathrm{LV}$ & Level instrument \\
\hline $\mathrm{MACT}$ & Maximum achievable control technology \\
\hline $\mathrm{mg}$ & Milligrams \\
\hline $\mathrm{min}$ & Minute \\
\hline $\mathrm{ml}$ & Milliliters \\
\hline $\mathrm{MM}$ & Million \\
\hline $\mathrm{N}$ & Nitrogen element \\
\hline $\mathrm{N}_{2}$ & Nitrogen gas \\
\hline & \\
\hline
\end{tabular}




\begin{tabular}{|l|l|}
\hline $\mathrm{NaCl}$ & Sodium chloride \\
\hline $\mathrm{ng}$ & Nanograms \\
\hline $\mathrm{N}_{2} \mathrm{O}$ & Nitrous oxide \\
\hline $\mathrm{NO}_{x}$ & Nitrogen oxides \\
\hline $\mathrm{O}$ & Oxygen element \\
\hline $\mathrm{O}_{2}$ & Oxygen gas \\
\hline $\mathrm{OD}$ & Outer diameter \\
\hline $\mathrm{OZ}$ & Ounce \\
\hline $\mathrm{P}$ & Pressure \\
\hline $\mathrm{PAS}$ & Pollution-abatement system \\
\hline $\mathrm{Pb}$ & Lead \\
\hline $\mathrm{PCB}$ & Polychlorinated biphenyl \\
\hline $\mathrm{PCDD}$ & Polychlorinated dibenzodioxin \\
\hline $\mathrm{PCDF}$ & Polychlorinated dibenzofuran \\
\hline $\mathrm{PFD}$ & Process flow diagram \\
\hline ppbvd & Parts per billion by volume dry \\
\hline ppm & Parts per million \\
\hline psi & Pounds per square inch \\
\hline psia & Pounds per square inch absolute \\
\hline psig & Pounds per square inch gauge \\
\hline $\mathrm{Pu}$ & Plutonium \\
\hline $\mathrm{PVC}$ & Polyvinyl chloride \\
\hline $\mathrm{RCRA}$ & Resource Conservation and Recovery Act \\
\hline $\mathrm{S}$ & Sulfur \\
\hline Sb & Antimony \\
\hline scfm & Standard cubic feet per minute \\
\hline SCWO & Supercritical water oxidation \\
\hline SO & Sulfur oxides \\
\hline SRS & Savannah River Site \\
\hline $\mathrm{T}$ & Temperature \\
\hline TCLP & Toxicity Characteristic Leaching Procedure \\
\hline TD & Thermal desorption \\
\hline TEQ & Toxic equivalent \\
\hline TOC & Total organic carbon \\
\hline TRUPACT & TRansUranic PACkage Transporter \\
\hline VOC & Volatile organic compound \\
\hline WAC & Waste Acceptance Criteria \\
\hline WIPP & Waste Isolation Pilot Plant \\
\hline wt & Weight \\
\hline$\tau$ & Residence time \\
\hline$i g$ & Microgram \\
\hline & \\
\hline & \\
\hline
\end{tabular}




\section{EXECUTIVE SUMMARY}

The United States Department of Energy's Savannah River Site (SRS), near Aiken, South Carolina, stores high activity plutonium-238-contaminated transuranic waste. This waste may not be shippable to the Waste Isolation Pilot Plant (WIPP) in TRUPACT-II containers due to excessive generation of hydrogen gas as a result of radiolysis of organic constituents in the waste matrix. Nonincineration means are sought by DOE for treatment of this waste to destroy the organics, eliminating the source of hydrogen, which would allow the waste to meet the TRUPACT-II hydrogen-concentration limit and the WIPP waste acceptance criteria (WAC). Under DOE Solicitation No. PRDA DE-RA26-01NT40981, GA was awarded a Phase I contract to perform surrogate mixed waste cold demonstration tests for a technology known as thermal desorption-supercritical water oxidation (TD-SCWO) for reducing the organic content to acceptable levels. GA combines two well-known and effective treatment processes, thermal desorption (TD) and supercritical water oxidation (SCWO), to achieve enhancements not possible with either technology alone, or with other potentially competitive technologies. GA is focusing on a full-scale batch process for 55-gallon drums of mixed transuranic waste at the Savannah River Site.

TD is well established as a treatment process for removal of organics from difficult solid matrices such as soils and mixed wastes. Heat is used to volatilize, gasify and transport organics from the inorganic residue for subsequent treatment. SCWO is a well-developed nonincineration process for destruction of organics in pumpable forms such as liquids and slurries of finely divided particles. SCWO oxidizes organics in a steam medium at elevated temperatures and pressures in a manner that achieves excellent destruction efficiencies and compliance with all environmental requirements without the need for complex pollutionabatement equipment. While typically operated at a pressure above the critical pressure for water (>3206 psia), GA has found that robust reaction and destruction efficiencies persist to pressures well below 1000 psi (Ref. 1, 2). In the Phase I work both TD and SCWO processes were operated at the relatively low pressure of 500 psi.

The primary objective of the Phase I Program was to demonstrate the ability of TD-SCWO to remove hydrogen from surrogate hydrogenous waste streams by nonincineration means. To qualify as a suitable technology, the proposed system would also have to show near-absolute containment of surrogate radionuclides and require minimal pre-treatment and post-treatment. Other test objectives were to verify that the process produces no dioxins or furans, and meets all applicable regulatory criteria for retention of toxic metals, particulate, and criteria pollutants, while meeting WIPP/WAC and TRUPACT-II requirements.

The Phase I testing utilized surrogate waste matrices chosen to be representative of Savannah River Site transuranic mixed wastes. Three different recipes comprising various mixtures of wood, paper, plastic, metal, leaded gloves, clay adsorbent and HEPA filters (primarily fiberglass) were used. Cerium oxide was added in a molar quantity to mimic plutonium-238 at a level of 5.7 grams per 55-gal drum, the maximum target value for TRUPACT-II containers. Carbon tetrachloride $\left(\mathrm{CCl}_{4}\right)$ and perchloroethylene $\left(\mathrm{C}_{2} \mathrm{Cl}_{4}\right)$ spikes were added in amounts of 1 wt\%. For each test the chosen feed mixture was packed into a 1.7-gal canister lined with thin PVC sheet to simulate a lined drum. The packed canister was then inserted in the thermal desorber unit to be processed by TD-SCWO.

The Phase I test results show that the GA TD-SCWO process operates as intended. Results are summarized in Table ES-1. All TD success criteria were demonstrated. The TD step provided a high degree of hydrogen removal and full containment of the cerium radionuclide 
surrogate. The requirement for less than $5 \%$ hydrogenous organic in the residue was bettered by factors ranging from 2.5 to 33 . With proper SCWO reactor temperature, all SCWO success criteria were also believed to be met, although the requirement of $>99.99 \%$ destruction and removal efficiency (DRE) for chlorinated solvents has not yet been demonstrated.

Table ES-1. TD-SCWO Success Criteria

\begin{tabular}{|c|c|c|}
\hline Requirement & Success Criteria & Status \\
\hline Nonincineration & $\begin{array}{l}\text { Peak process temperature measured via } \\
\text { thermocouple to be }<1600^{\circ} \mathrm{F}\left(871^{\circ} \mathrm{C}\right)\end{array}$ & $\begin{array}{c}\text { Demonstrated, } \\
\text { see Figures 9-12 }\end{array}$ \\
\hline Hydrogen Removal & Total hydrogenous organic in residue $<5$ wt \% & $\begin{array}{l}\text { Demonstrated, } \\
\text { see Table } 8 \\
\end{array}$ \\
\hline $\begin{array}{l}\text { Destruction and } \\
\text { Removal Efficiency }\end{array}$ & $\begin{array}{l}\text { Spiked constituents }\left(\mathrm{CCl}_{4} \text { and } \mathrm{C}_{2} \mathrm{Cl}_{4}\right) \text { measured in } \\
\text { gaseous effluent to verify compliance with }>99.99 \% \\
\text { destruction and removal }\end{array}$ & $\begin{array}{l}\text { Demonstrated } \\
\sim 99.9 \% \text { DRE }\end{array}$ \\
\hline $\mathrm{CO}$ & CO level in gaseous effluent verified to be $<100 \mathrm{ppm}$ & $\begin{array}{l}\text { Demonstrated, } \\
\text { see Figures } 10-12\end{array}$ \\
\hline $\begin{array}{l}\text { Particulate } \\
\text { Emissions }\end{array}$ & $\begin{array}{l}\text { Particulate level in gaseous effluent verified to be } \\
<0.015 \text { grains/dscf }\end{array}$ & $\begin{array}{l}\text { Demonstrated, } \\
\text { see Table } 6\end{array}$ \\
\hline Mercury Removal & $\begin{array}{l}\text { Hg level in gaseous effluent verified to be }<45 \\
\mu \mathrm{g} / \mathrm{dscm}\end{array}$ & $\begin{array}{l}\text { Demonstrated, } \\
\text { see Table } 6 \text { (no } \\
\text { Hg added to feed) }\end{array}$ \\
\hline $\begin{array}{l}\text { Cadmium and Lead } \\
\text { Removal }\end{array}$ & $\begin{array}{l}\mathrm{Cd}+\mathrm{Pb} \text { level in gaseous effluent verified to be } \\
<0.024 \mathrm{mg} / \mathrm{dscm}\end{array}$ & $\begin{array}{l}\text { Demonstrated, } \\
\text { see Table } 6\end{array}$ \\
\hline $\begin{array}{l}\text { Antimony, Arsenic, } \\
\text { Beryllium, and } \\
\text { Chromium Removal }\end{array}$ & $\begin{array}{l}\mathrm{Sb}+\mathrm{As}+\mathrm{Be}+\mathrm{Cr} \text { level in gaseous effluent verified } \\
\text { to be }<0.097 \mathrm{mg} / \mathrm{dscm}\end{array}$ & $\begin{array}{l}\text { Demonstrated, } \\
\text { see Table } 6\end{array}$ \\
\hline $\begin{array}{l}\text { Radioactive Particle } \\
\text { Containment }\end{array}$ & $\begin{array}{l}\text { Measure } \mathrm{CeO}_{2} \text { levels in gaseous and liquid effluent } \\
\text { to determine degree of containment }\end{array}$ & $\begin{array}{l}\text { Demonstrated, } \\
\text { see Tables 4-6 }\end{array}$ \\
\hline $\begin{array}{l}\text { Minimum } \\
\text { Pretreatment }\end{array}$ & $\begin{array}{l}\text { Minimum pretreatment requirements relative to other } \\
\text { technologies }\end{array}$ & Demonstrated \\
\hline $\begin{array}{l}\text { Minimum } \\
\text { Posttreatment }\end{array}$ & $\begin{array}{l}\text { Minimum posttreatment gas cleaning process } \\
\text { relative to other technologies }\end{array}$ & Demonstrated \\
\hline $\begin{array}{l}\text { Dioxin/Furan } \\
\text { Emissions }\end{array}$ & $\begin{array}{l}\text { Total dioxins and furans in gaseous effluent verified } \\
\text { to be less than regulated levels of } 0.2 \mathrm{ng} / \mathrm{dscm} \\
\text { (TEQ) at } 7 \% \mathrm{O}_{2}\end{array}$ & $\begin{array}{l}\text { Demonstrated, } \\
\text { see Table } 6\end{array}$ \\
\hline WIPP/WAC & Meets requirements & $\begin{array}{l}\text { Demonstrated, } \\
\text { see Table } 9\end{array}$ \\
\hline TRUPACT-II & Meets requirements & $\begin{array}{c}\text { Demonstrated, } \\
\text { see Table } 9\end{array}$ \\
\hline
\end{tabular}


Key conclusions from the Phase I testing are as follows:

- Thermal desorption of surrogate SRS mixed wastes at $500 \mathrm{psi}$ and $1000^{\circ} \mathrm{F}$ meets all tested requirements for WIPP/WAC and TRUPACT-II.

- SCWO of the desorbed surrogate organic materials at 500 psi and $1500^{\circ} \mathrm{F}$ appears to meet all requirements for a nonincineration alternative. DRE for chlorinated solvents was slightly less than required during the lower temperature SCWO tests, so this temperature should be maintained to insure destruction.

- TD-SCWO technology is ready to proceed to Phase III, the full-scale module cold demonstration. (As per the PRDA, Phase II is not applicable to destruction technologies such as TD-SCWO.)

In summary, GA has demonstrated what may be a revolutionary new method for destruction of organics in mixed wastes that exist across the DOE complex. This new thermal treatment process is ideally suited to treating 55-gal drums of mixed waste without removing the materials from the drum. The process can also be adapted for continuous feed of bulk mixed wastes such as soils.

A Phase III Demonstration Program is needed to bring this new technology to full-scale, and to ready it for deployment at DOE sites with problematic mixed wastes. 


\section{INTRODUCTION}

The United States Department of Energy's Savannah River Site (SRS), near Aiken, South Carolina, stores high activity plutonium-238-contaminated transuranic waste. This waste may not be shippable to the Waste Isolation Pilot Plant (WIPP) in TRUPACT-II containers due to excessive generation of hydrogen gas as a result of radiolysis of organic constituents in the waste matrix. Nonincineration means are sought by DOE for treatment of this waste to destroy the organics, eliminating the source of hydrogen, which would allow the waste to meet the TRUPACT-II hydrogen-concentration limit and the WIPP waste acceptance criteria (WAC). Under DOE Solicitation No. PRDA DE-RA26-01NT40981, GA was awarded a Phase I contract to perform surrogate mixed waste tests to demonstrate the feasibility of a technology known as thermal desorption-supercritical water oxidation (TD-SCWO) for reducing the organic content to acceptable levels.

General Atomics (GA) is developing a two-step alternative to incineration for the destruction of organics in transuranic wastes at the Savannah River Site (SRS). GA combines two well-known and effective treatment processes, thermal desorption (TD) and supercritical water oxidation (SCWO), to achieve enhancements not possible with either technology alone, or with other potentially competitive technologies. GA is focusing on a batch process for 55-gallon drums of mixed transuranic waste at the Savannah River Site.

TD is well established as a treatment process for removal of organics from difficult solid matrices such as soils and mixed wastes. Heat is used to volatilize, gasify and transport organics from the inorganic residue for subsequent treatment. SCWO is a well-developed nonincineration process for destruction of organics in pumpable forms such as liquids and slurries of finely divided particles. SCWO oxidizes organics in a steam medium at elevated temperatures and pressures in a manner that achieves excellent destruction efficiencies and compliance with all environmental requirements without the need for complex pollutionabatement equipment. While typically operated at a pressure above the critical pressure for water (>3206 psia), GA has found that robust reaction and destruction efficiencies persist to pressures well below 1000 psi (Ref. 1,2). GA combines the TD and SCWO processes at a relatively low pressure of 500 psi to achieve removal and destruction of organics from solid matrices with minimum pretreatment and posttreatment requirements.

The integrated TD-SCWO process overcomes two fundamental problems, one related to TD and the other to SCWO. Traditionally, TD requires an afterburner and a complex pollutionabatement system (PAS) to destroy the desorbed organics, thus violating the non-incineration objective and compromising permitting and public acceptance. For the SRS application, the spread of Pu-238 contamination throughout the afterburner and PAS further compromises traditional TD technology. Traditionally, SCWO feed materials must be liquids or finely ground solids that can be slurried and pumped to high pressure. With TD-SCWO, however, TD desorbs organics from any form of solids and delivers the gas-phase organics to SCWO, thus resolving the feed pretreatment requirements of SCWO. In turn, SCWO resolves the afterburner/PAS requirements of TD by destroying the organics at SCWO conditions and capturing particulates, acids, and any other pollutants in the liquid effluent, and avoiding dioxin formation by rapid quench at the reactor outlet.

Integration of TD and SCWO subsystems is accomplished by operating at pressures of about 500 psig, retaining the advantages of SCWO and containing bulk solids in the pressurized TD. For the SRS application, a 55-gallon drum batch system is envisioned to minimize pretreatment 
requirements and the potential spread of Pu-238 contamination. The proposed work was to be performed in phases as follows:

- Phase I - Proof of Principle Cold Demonstration

- Phase II - Proof of Principle Actual Waste Demonstration (decontamination technologies only, not applicable to TD-SCWO)

- $\quad$ Phase III $-1 / 5^{\text {th }}$ or Larger Scale Cold Demonstration

- Phase IV $-1 / 5^{\text {th }}$ or Larger Quantification and Actual Waste Treatment

This report covers the experimental work undertaken for the first phase of the overall development program, referred to as the Proof of Principle Cold Demonstration. Test results show that the process operates as intended. It provides a high degree of hydrogen removal and full containment of the radionuclide surrogate. All TD success criteria were demonstrated. All SCWO success criteria were also demonstrated with the exception of chlorinated solvent destruction and removal efficiency (DRE), which was slightly less than the target DRE during lower temperature tests. Maintaining somewhat higher SCWO temperatures will insure meeting the DRE success criterion. The process is ready to proceed to Phase III, the full-scale module cold demonstration. The facility at SRS may be comprised of as many as 5 full-scale modules, hence this demonstration has previously been referred to as " $1 / 5^{\text {th }}$ scale".

\section{TEST OBJECTIVES}

The primary objective of the Phase I Program was to demonstrate the ability of TD-SCWO to remove hydrogen from surrogate hydrogenous waste streams by nonincineration means. To qualify as a suitable technology, the proposed system would also have to show near-absolute containment of surrogate radionuclides and require minimal pre-treatment and post-treatment. Other test objectives were to verify that the process produces no dioxins or furans, and meets all applicable regulatory criteria for retention of toxic metals, particulate, and criteria pollutants, while meeting WIPP, WAC, and TRUPACT-II requirements. The Phase I testing utilized surrogate waste matrices chosen to be representative of Savannah River Site transuranic mixed wastes.

\section{DESCRIPTION OF EQUIPMENT AND SET-UP}

A process flow diagram (PFD) for the integrated TD-SCWO pilot plant at GA is shown in Fig. 1. To simulate an open 55-gal drum, a polyvinyl chloride (PVC)-lined steel canister without a top is packed with waste surrogate. The canister is placed within the desorber from the top and the desorber top head is then installed. A novel feature of this testing is the use of 500 psi as the SCWO operating pressure, which results in a much lower density reaction medium in comparison to the conventional SCWO operating pressure of 3400 psi.

To start the SCWO system, process water is supplied at 500 psi by the high pressure water pump, mixed with air supplied by a compressor, and passed through the heater. In the heater the process water and air are heated and vaporized by impedance heating, in which low voltage electrical current is passed through the walls of the piping. The resulting steam/air mixture heats the reactor to a temperature of about $700^{\circ} \mathrm{F}$, at which point flow of auxiliary fuel (ethanol or diesel fuel) is begun. Reaction is initiated, and the heat of reaction brings the reactor temperature up to the nominal operating temperature of $1200-1500^{\circ} \mathrm{F}$. Flow of cold, high pressure dilution water is now begun while the SCWO system is maintained at full operating 


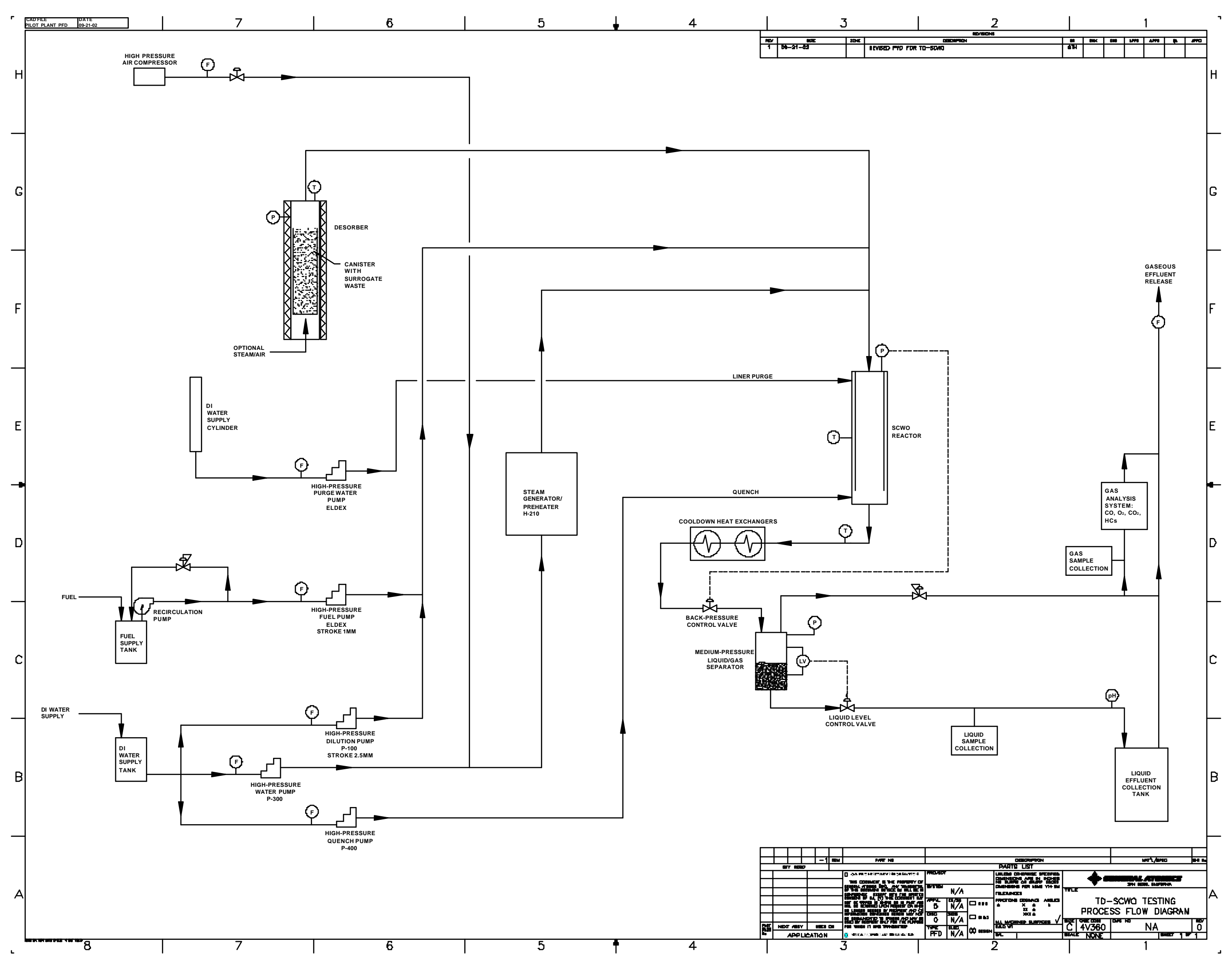

Figure 1. Process Flow Diagram (PFD) for GA TD-SCWO pilot plant. 
conditions with auxiliary fuel awaiting the introduction of waste vapors from the desorber section.

Once the SCWO system has been started, the desorber wall heaters are energized. The pressure within the desorber is controlled at 500 psi by the back pressure of the SCWO system, and helps to access any containers within the canister to expose organics to desorption. As the desorber heats up, volatilized waste constituents pass through a heated line to the top of the SCWO reactor and are oxidized as they combine with excess oxidant in the reactor and then flow towards the reactor bottom. The flows of fuel and dilution water to the SCWO reactor are adjusted to compensate for the heating caused by oxidation of the TD vapors while air flow is kept constant.

In the SCWO reactor, the main constituents of the TD waste vapor are converted to $\mathrm{CO}_{2}$ and $\mathrm{H}_{2} \mathrm{O}$ in the oxidizing steam environment. Organically-bound nitrogen, e.g. from wood, is converted to a combination of $\mathrm{N}_{2}$ and $\mathrm{N} 2 \mathrm{O}$, while sulfur is converted to $\mathrm{H}_{2} \mathrm{SO}_{4}$. $\mathrm{HCl}$ desorbed from the TD unit remains as $\mathrm{HCl}$. Following mixing and oxidation the process stream flows to the SCWO reactor bottom where it mixes with a cold (and optionally alkaline) quench stream. Acid gases are converted to dissolved acids or salts and mercury, if present, is solubilized as mercuric chloride.

As shown in Fig. 1, the SCWO reactor incorporates a removable liner. The liner is fabricated from a suitable corrosion-resistant material, in this case titanium which has high resistance to chloride. The liner is relatively cheap and is easily removable to allow for the use of different materials, or for replacement should corrosion of the liner occur. In addition to isolating the reactor pressure vessel from corrosive species, the liner is purged with steam or nitrogen and has metallic insulation on its outer surface that shields the pressure vessel from the high temperatures in the reaction zone.

The quenched stream, with gases and dissolved salts, now exits the reactor. It is cooled to near ambient temperature by a series of annular heat exchangers with cooling water flowing through the annulus. The cooled process effluent is reduced in pressure to $250 \mathrm{psi}$ and then flows to a gas-liquid separator from which the liquid and gas streams are depressurized separately. Following pressure letdown, the liquid effluent is monitored for $\mathrm{pH}$. Liquid samples are collected as required from the line feeding the collection tank or from the collection tank itself.

The depressurized gas product is continuously analyzed on-line for $\mathrm{CO}, \mathrm{CO}_{2}$, and $\mathrm{O}_{2}$ content. Discrete gas samples can also be collected for later analysis. The gaseous effluent can be vented through a HEPA filter and a sulfur-impregnated carbon filter to capture any particles or mercury that may be present.

After desorption is complete, nominally a 7-hr period, the desorber wall heaters are turned off. The SCWO unit is shut down by discontinuing fuel flow. The reaction extinguishes and the heater is shut off. Cold water and air continue to flow to cool the reactor below $200^{\circ} \mathrm{F}$, at which point all flows are stopped and the system is depressurized. Any desired inspections of the TDSCWO system are now carried out. In particular, the desorber head is opened and the canister with residual solids is removed for inspection.

The key equipment items in the TD-SCWO system are the thermal desorber and the SCWO reactor. Diagrams of these vessels are shown in Figs. 2 and 3, respectively. A canister is 


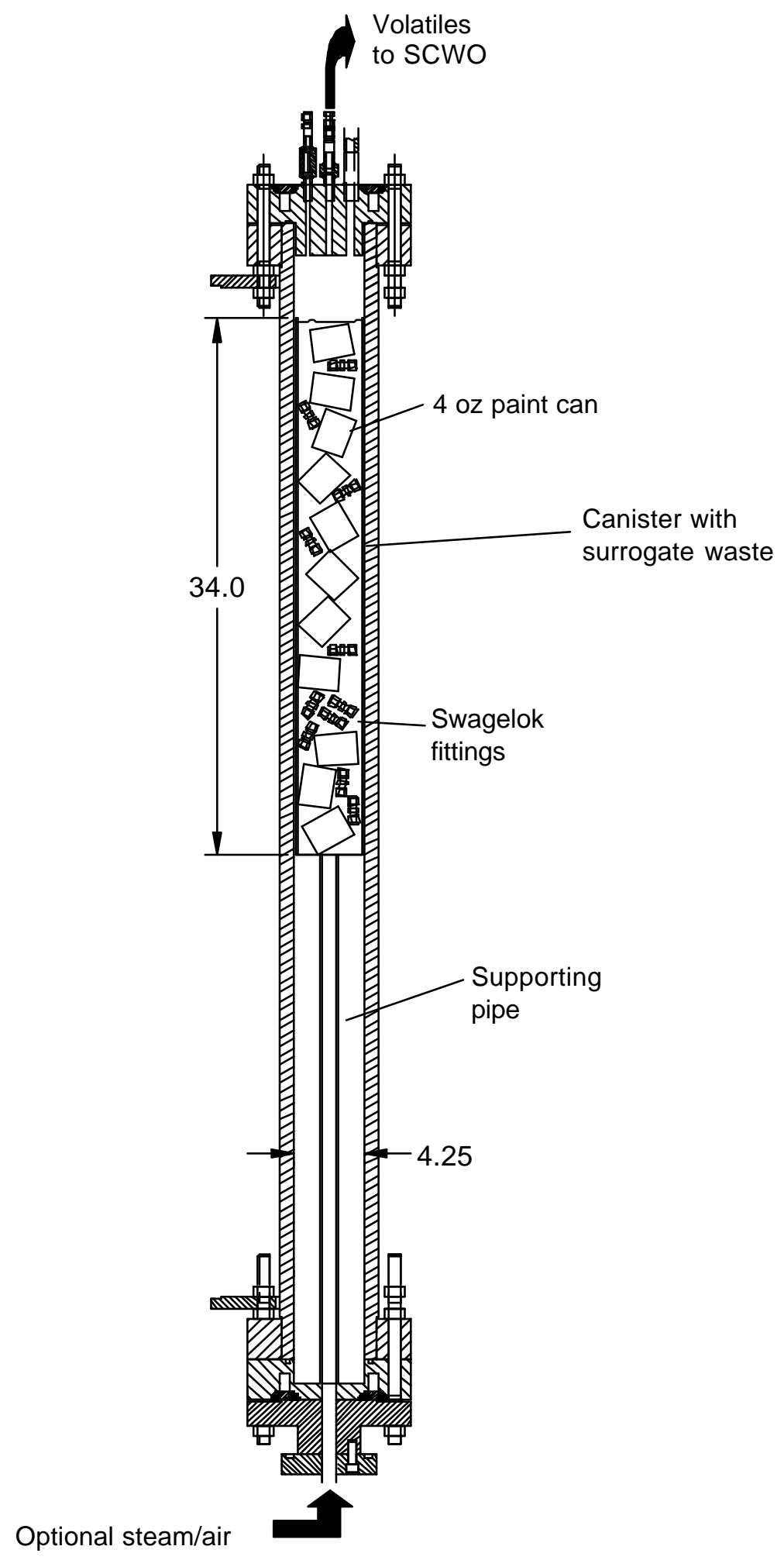

Figure 2. Pilot plant thermal desorber. Dimensions in inches. 


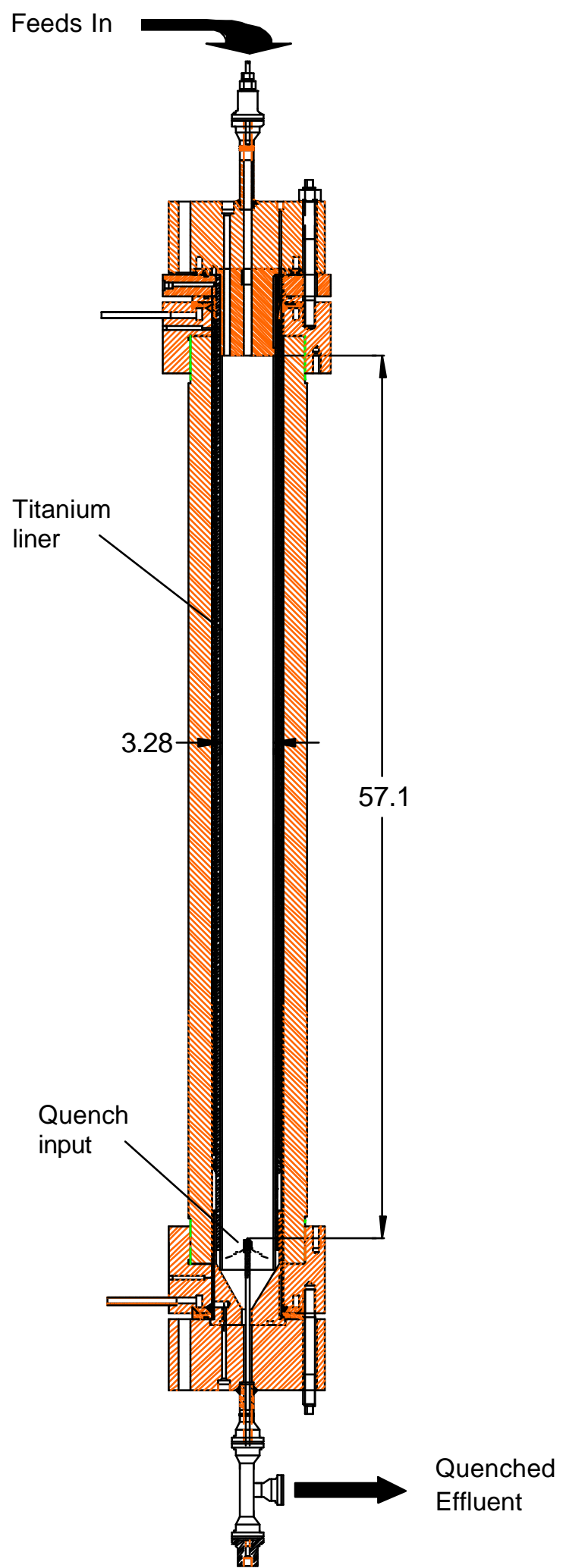

Figure 3. Pilot plant SCWO reactor. Dimensions in inches. 
shown within the desorber vessel in Figure 2. The general purpose thermal desorber has a design limit of $1150^{\circ} \mathrm{F}$ at $4000 \mathrm{psi}$. The general purpose SCWO reactor has a design limit of $1200^{\circ} \mathrm{F}$ at $4000 \mathrm{psi}$. Both vessels are operated at a reduced pressure of $500 \mathrm{psi}$ for the SRS mixed waste application.

The canister to hold the waste charge in the pilot plant thermal desorber is fabricated of mild steel, with a length of about 34 in. (to mimic the 55-gal drums that would be used in the fullscale plant), an OD of 4 in. (maximum possible to fit within the desorber) and a wall thickness of 0.032 in. (minimum workable thickness). The bottom end of the canister is closed by welding on a disc of 0.032 in. steel. Thin PVC sheet of 0.012-in. thickness was used to line the canister to mimic the drum lining. The final volume within the lined canister is about 1.7 gallons, or about $3 \%$ of the size of an actual drum. Multiple canisters were made and canisters were sometimes reused.

Figure 4 shows the size of a canister as compared to a 55-gallon drum. The full height used for the canister was chosen to provide a worst case condition in terms of desorption path length.

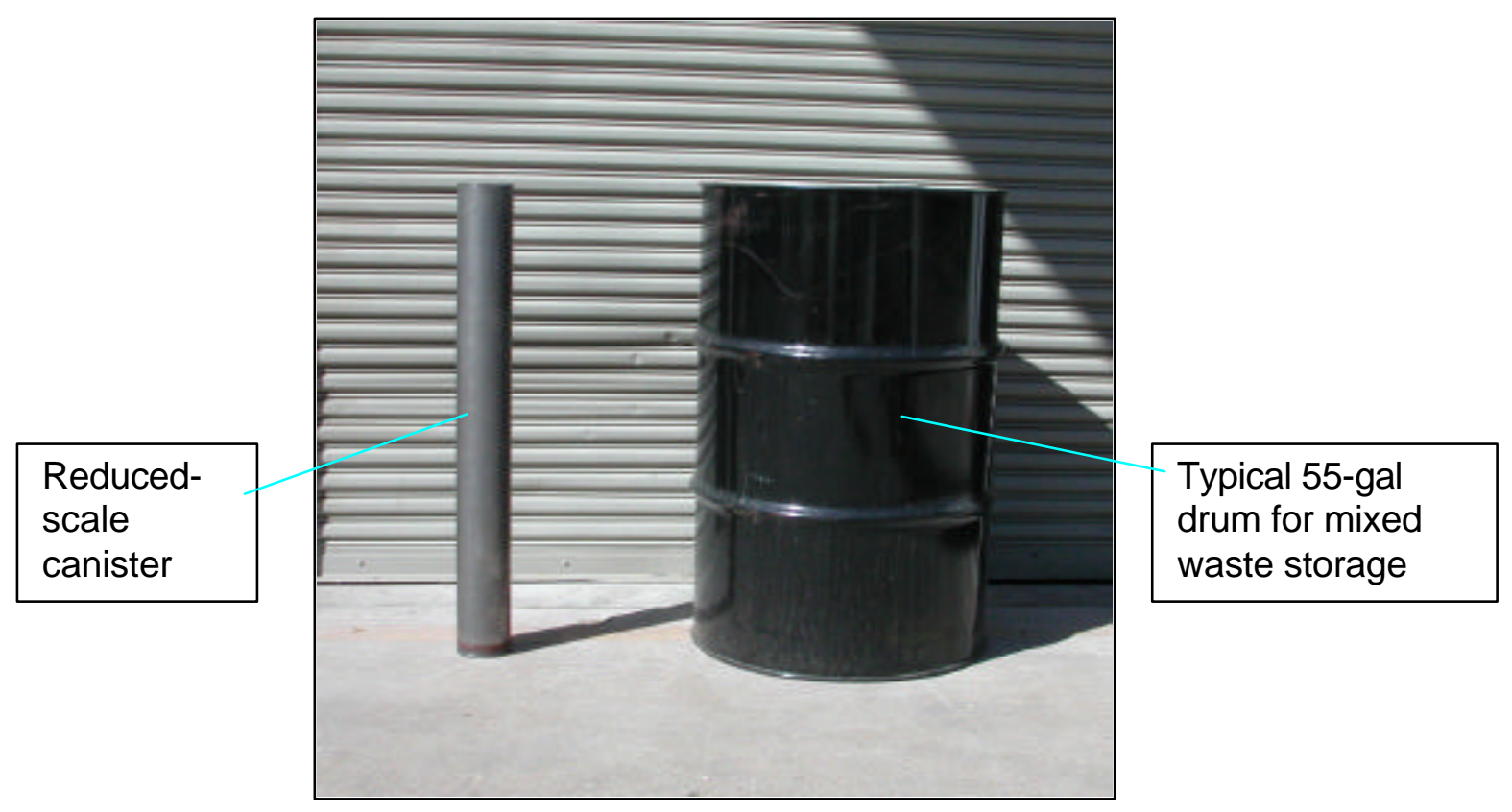

Figure 4. Pilot plant TD canister and 55-gal drum.

Figures 5 through 7 are photographs of the thermal desorber, the SCWO reactor skid, and the SCWO reactor. Figures 5 and 7 correspond to the drawings of Figures 2 and 4, respectively. The proprietary appendix contains additional information regarding the equipment setup and operation. 


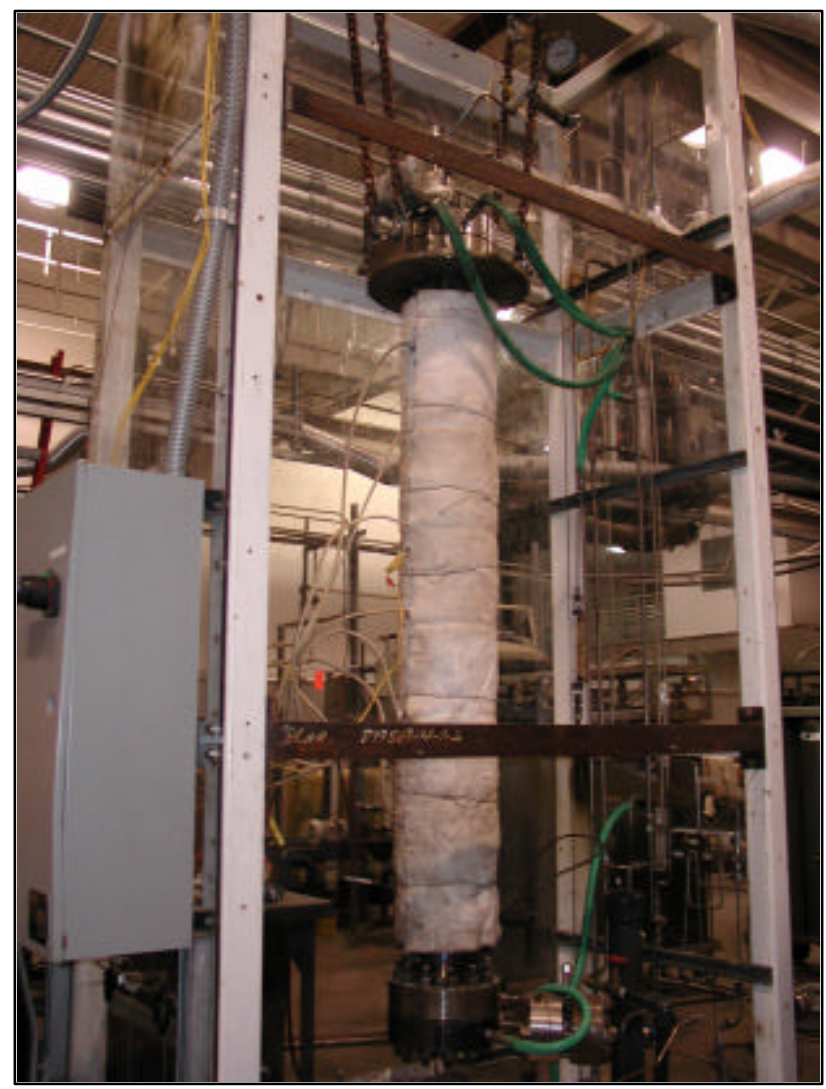

Figure 5. Pilot plant thermal desorber.

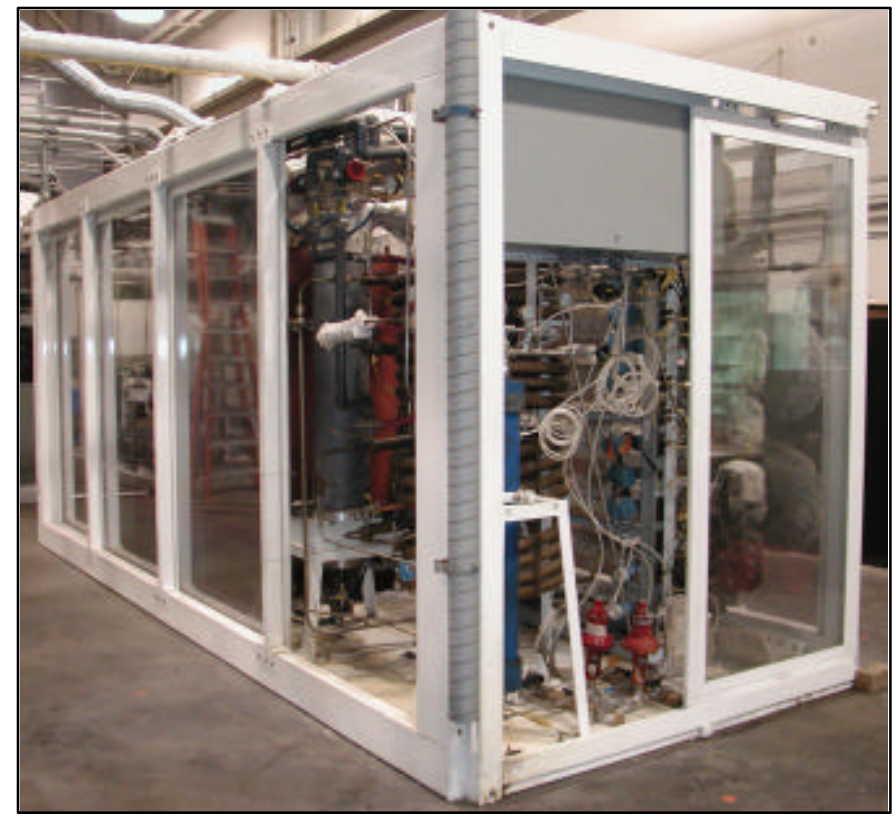

Figure 6. Pilot plant SCWO reactor skid. 


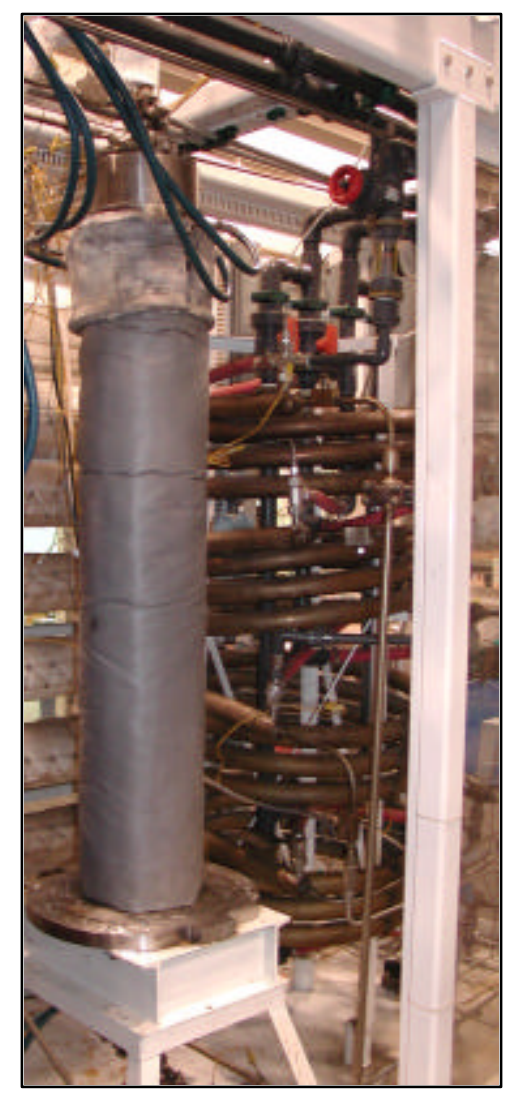

Figure 7. Pilot plant SCWO reactor.

Table 1 lists the surrogate recipes used in the testing. The recipes are based on typical drum compositions suggested by the Savannah River Site in December 2001. Cerium oxide has been added in a molar quantity to mimic plutonium-238 at a level of 5.7 grams per 55-gal drum, the maximum target value for TRUPACT-II containers. Carbon tetrachloride $\left(\mathrm{CCl}_{4}\right)$ and perchloroethylene $\left(\mathrm{C}_{2} \mathrm{Cl}_{4}\right)$ spikes have been added in amounts of $1 \mathrm{wt} \%$. Recipes do not include the weight of the drum/canister or PVC lining. The PVC lining was simulated by placing 34 grams of thin PVC sheet within the canister ID.

As shown in the table, recipe \#1 contained about $600 \mathrm{~g}$ of volatile material, recipe \#2 about $1000 \mathrm{~g}$ of volatile material, and recipe \#3 about $1500 \mathrm{~g}$ of volatile material. Recipe \#1 has the highest percentage of chlorine, about $10 \mathrm{wt} \%$. Recipe \#2 contains only about $5 \mathrm{wt} \%$ chlorine, but due to its greater mass has twice as much chlorine as Recipe \#1 in absolute terms. Recipe \#3 has only $1.7 \mathrm{wt} \%$ chlorine. 
Table 1. Surrogate Recipes

\begin{tabular}{|c|c|c|c|c|}
\hline Surrogate \#1: Average Composition & wt\% & $\begin{array}{l}\text { kg per } \\
55-\text { gal } \\
\text { drum }\end{array}$ & $\begin{array}{c}\text { g per } \\
1.7-\text { gal } \\
\text { canister }\end{array}$ & Notes \\
\hline Iron base metal alloys & 10.1 & 2.47 & 77.5 & Use steel and stainless steel hardware \\
\hline Other metals/Alloys & 0.2 & 0.06 & 1.9 & Use brass fittings \\
\hline Oil Dry adsorbent & 7.1 & 1.74 & 54.6 & Purchase \\
\hline Paper/Wood & 38.8 & 9.5 & 298.2 & Use available scrap \\
\hline Lead lined gloves & 0.9 & 0.21 & 6.6 & Some supplied by SRS \\
\hline PVC, polyethylene & 40.9 & 10 & 313.9 & Use household bags \\
\hline $\mathrm{CeO}_{2}$ & 0.017 & & 0.129 & Purchase \\
\hline $\mathrm{CCh}_{4}$ & 1.0 & & 7.5 & Purchase \\
\hline $\mathrm{C}_{2} \mathrm{Cl}_{4}$ & 1.0 & & 7.5 & Purchase \\
\hline Total & 100.0 & 24.0 & 767.8 & \\
\hline Approximate volatile content & & & 600 & \\
\hline \multicolumn{5}{|l|}{ Surrogate \#2: High metal and Lead } \\
\hline Lead lined gloves & 22.0 & 24.2 & 760.3 & Some supplied by SRS \\
\hline Other gloves (latex) & 9.8 & 10.8 & 338.0 & Purchase \\
\hline PVC/Poly bags & 4.5 & 4.9 & 154.9 & Use household bags \\
\hline Metal pieces (fittings) & 59.4 & 65.5 & 2055.2 & Use stainless steel fittings \\
\hline Paint cans (empty but closed) & 2.5 & 2.7 & 85.5 & Use 4 oz. paint cans \\
\hline $\mathrm{CeO}_{2}$ & 0.002 & & 0.1 & Purchase \\
\hline $\mathrm{CCl}_{4}$ & 1.0 & & 33.9 & Purchase \\
\hline $\mathrm{C}_{2} \mathrm{Cl}_{4}$ & 1.0 & & 33.9 & Purchase \\
\hline Total & 100.0 & 108.1 & 3461.8 & \\
\hline Approximate volatile content & & & 1000 & \\
\hline \multicolumn{5}{|l|}{ Surrogate \#3: High Plastic and Adsorbent } \\
\hline Organics (isopropanol) on wipes & 11.0 & 8.6 & 271.2 & Moisten wipes with isopropanol \\
\hline Oil Dry adsorbent & 26.7 & 21.0 & 660.5 & Purchase \\
\hline Aerosol cans with cleaner & 5.2 & 4.1 & 128.7 & Use isopropanol in $4 \mathrm{oz}$. paint cans \\
\hline Glass (substitute for mercury thermometer) & 5.8 & 4.6 & 144.7 & Use available scrap \\
\hline Polypropylene & 47.8 & 37.7 & 1183.8 & Purchase \\
\hline HEPA Material & 1.5 & 1.2 & 37.5 & Purchase \\
\hline $\mathrm{CeO}_{2}$ & 0.005 & & 0.129 & Purchase \\
\hline $\mathrm{CCl}_{4}$ & 1.0 & & 24.3 & Purchase \\
\hline $\mathrm{C}_{2} \mathrm{Cl}_{4}$ & 1.0 & & 24.3 & Purchase \\
\hline Total & 100.0 & 77.3 & 2475.0 & \\
\hline Approximate volatile content & & & 1500 & \\
\hline
\end{tabular}




\section{TESTING}

\subsection{Thermal Desorber Tests}

The initial test series involved only the thermal desorber. A total of 36 such tests were carried out using the different surrogates and testing the effect of various parameters. Table 2 presents the parameters that were explored. The primary evaluation methods for these runs were observation of the varying rate of gas evolution, visual examination of the desorber residue and any tar or scale formation in the desorber exit line, and analysis of the canister residue for hydrogen. To determine gas evolution rate, the exit line from the desorber was passed through a coil in a water bath, through a liquid knockout trap, and then through a back-pressure regulator and a gas flowmeter. This setup provided information on the time course of volatilization and facilitated the setting of desorption parameters. Figure 8 shows the process flow diagram for the TD-only tests.

Table 2. Parameters for TD-Only Tests

\begin{tabular}{|c|c|c|}
\hline Parameter & Range & Result \\
\hline Pressure & 500-1000 psig & $\begin{array}{c}\text { Negligible difference between } 500 \text { and } 1000 \text { psi- } \\
\text { use } 500 \text { psi }\end{array}$ \\
\hline Temperature & $600-1150^{\circ} \mathrm{F}$ & $\begin{array}{c}932^{\circ} \mathrm{F}\left(500^{\circ} \mathrm{C}\right) \text { is sufficient for low residual } \\
\text { hydrogen }\end{array}$ \\
\hline $\begin{array}{c}\text { Desorption time } \\
\text { (heaters on to heaters off) }\end{array}$ & $1-8 \mathrm{hr}$ & $\begin{array}{l}\text { Low residual hydrogen can be achieved in } 2 \text { hours } \\
\text { - one hour heating up to } 932^{\circ} \mathrm{F} \text { and } 1 \text { hour holding } \\
\text { at } 932^{\circ} \mathrm{F}\end{array}$ \\
\hline Steam flow & $0-8 \mathrm{lb} / \mathrm{hr}$ & $\begin{array}{c}\text { Steam does little to reduce residual hydrogen and } \\
\text { exacerbates corrosion by wet hydrochloric acid. } \\
\text { Both } 316 \text { stainless steel and Alloy C-276 are } \\
\text { subject to such corrosion. }\end{array}$ \\
\hline Air flow & $0-1.4 \mathrm{scfm}$ & $\begin{array}{l}\text { Introduction of air to the TD unit causes combustion } \\
\text { and hot spots. Avoidance of hot spots requires } \\
\text { such a low flow rate as to be impractical. }\end{array}$ \\
\hline
\end{tabular}

\subsection{Thermal Desorber-SCWO Integration and Optimization Tests}

Following the TD-only tests the range of favorable desorber parameters was used to set conditions for the integrated TD-SCWO system. The TD heatup time was increased from about 2 hours to $4-7$ hours to properly match the SCWO reactor capacity. The longer heatup times are also closer to those expected for the full-scale application. The SCWO system was operated at essentially the same pressure as the desorber, $500 \mathrm{psi}$. During the integration and optimization tests a SCWO operating temperature of about $1300^{\circ} \mathrm{F}$ was found to be satisfactory, but this was eventually raised to $1540^{\circ} \mathrm{F}$ to reduce the $\mathrm{CO}$ spikes and insure good destruction efficiencies. The SCWO reactor residence time was 7-10 seconds. It was found that the SCWO effluent pH stayed above 2, and there was no need to use an alkaline quench. 


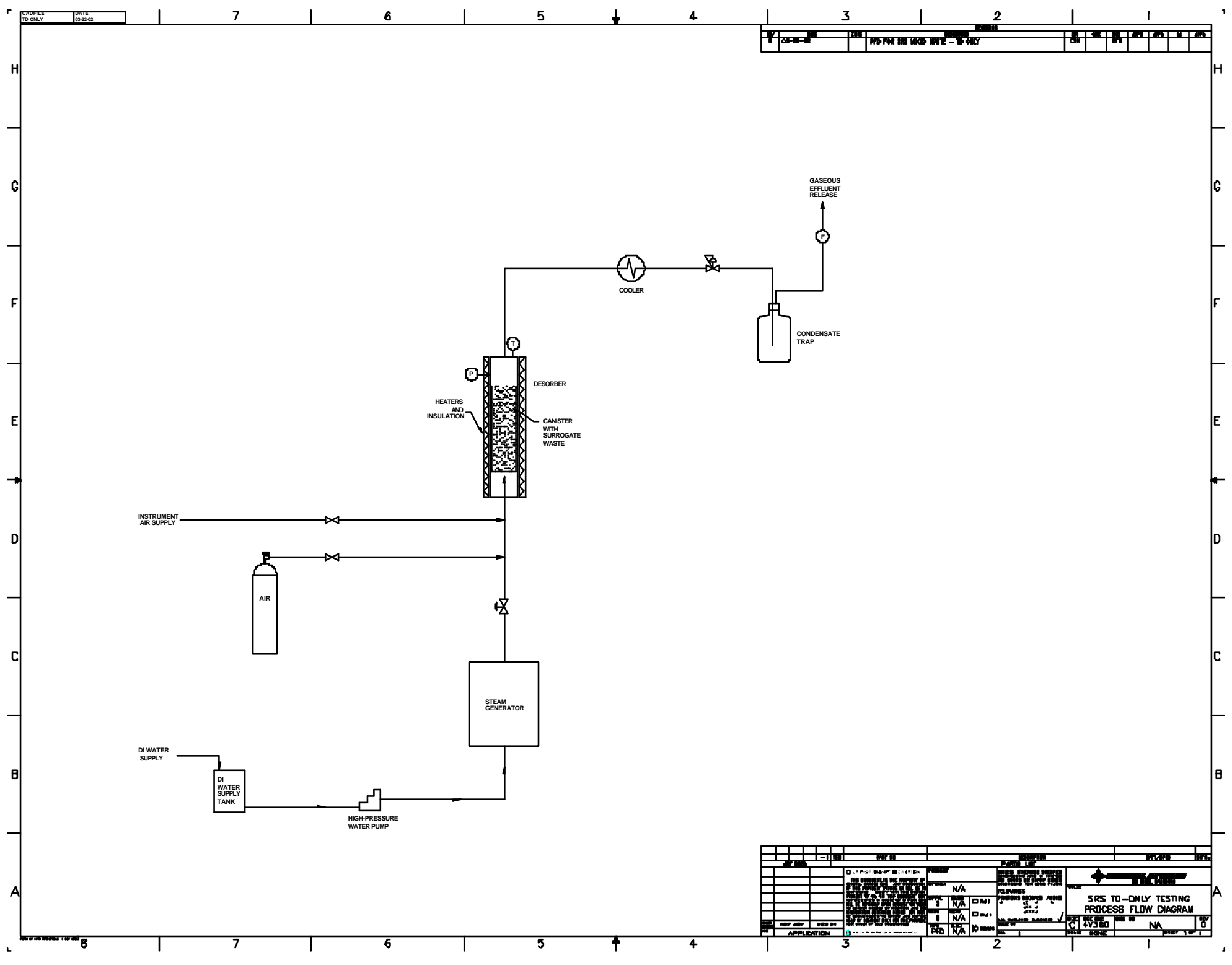

Figure 8. PFD for TD-only tests. 


\subsection{Demonstration Tests}

Following the TD-SCWO integration and optimization tests the final series of demonstration tests was undertaken. Appendix A provides a sample Run Plan for one of the TD-SCWO demonstration runs to illustrate system flows and procedures. Note that each successive run was performed at a slightly higher SCWO reactor temperature to reduce the CO spikes and improve destruction efficiencies during periods of high volatiles desorption.

\section{Surrogate Recipe \#2, $1300^{\circ} \mathrm{F}$ SCWO Temperature}

Figure 9 shows key data for Run 8.2, which utilized recipe \#2. The upper plot shows the thermal desorber heater set point temperature, which was controlled by thermocouples mounted on the outside wall of the desorber pressure vessel. There are actually three zones of "clam shell" heaters along the vessel and three separate heater controllers. For this test the heater set points were all entered manually, as indicated by the series of steps in the set point curve. Also shown in the upper plot is the TD internal temperature as measured by a thermocouple positioned just above the canister. In this case about 3 hours were required for the TD internal temperature to reach $\sim 932^{\circ} \mathrm{F}\left(500^{\circ} \mathrm{C}\right)$, and this temperature was then held for about 1 hour.

The lower plot in Figure 9 shows corresponding key data for the SCWO unit. The maximum reactor temperature was about $1300^{\circ} \mathrm{F}\left(700^{\circ} \mathrm{C}\right)$. The SCWO gas effluent shows two distinct episodes of oxygen drop and carbon dioxide rise, signifying peaks in the volatile material coming over from the TD unit. During these separate desorption intervals the SCWO reactor temperature dropped briefly to relatively low levels in the range of $900^{\circ} \mathrm{F}\left(500^{\circ} \mathrm{C}\right)$. The higher rate of volatiles would normally give a higher SCWO reactor temperature but the system operator was instructed to increase the flow rate of cold diluting water to the SCWO reactor to compensate for ncreasing temperatures. Close control of reactor temperature was difficult during high rates of desorption due to the rapidly changing rate of volatiles desorption. During the second episode of high volatiles in Figure 9 the TD set point was reduced to slow the rate of desorption.

The TD-SCWO integrated system performed well and the liquid effluent remained clean. 

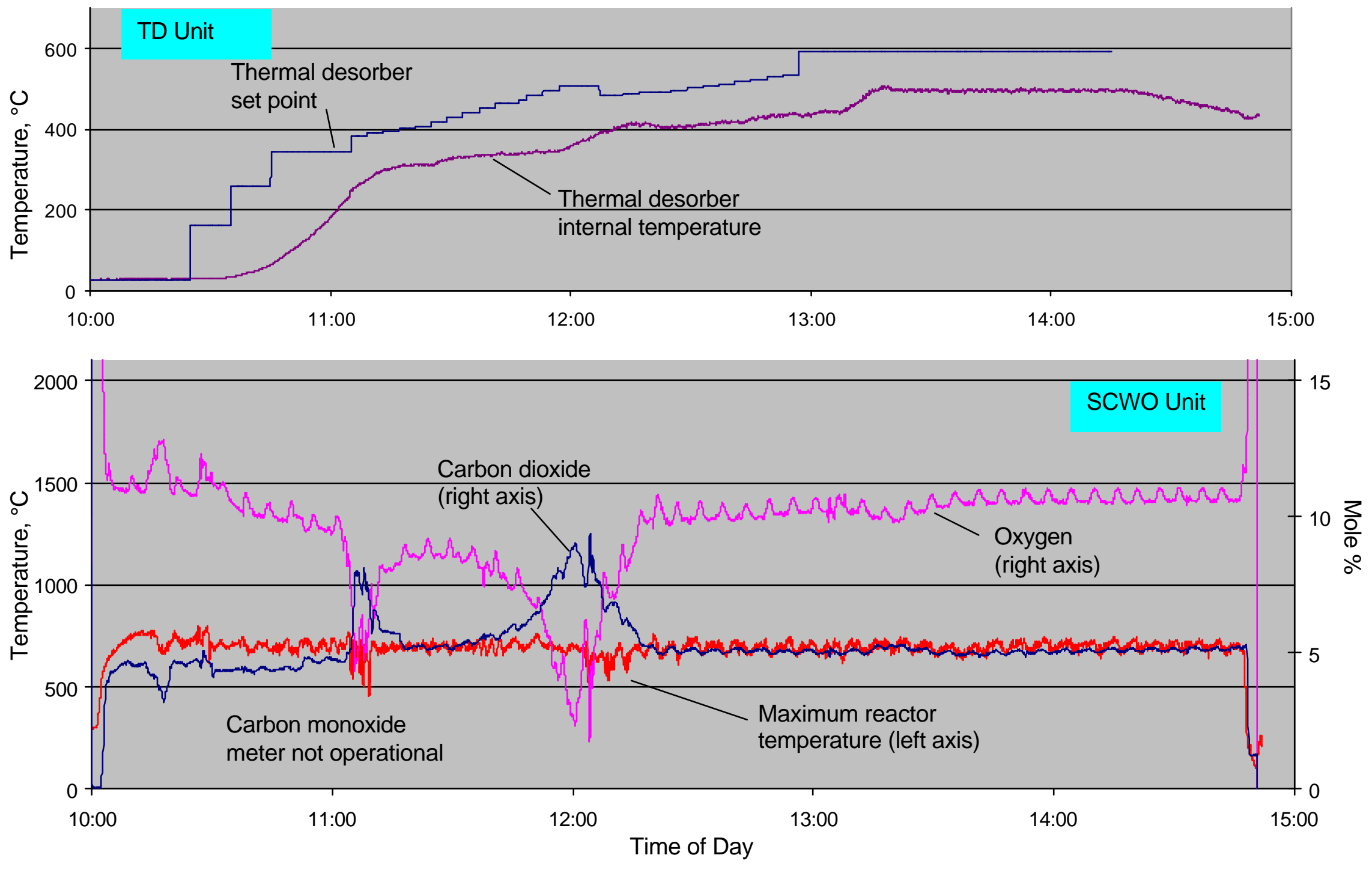

Figure 9. Plots for Run 8.2, recipe \#2. 


\section{Surrogate Recipe \#1, $1400^{\circ} \mathrm{F}$ SCWO Temperature}

Figure 10 shows key data for Run 10.1, which utilized recipe \#1. This was the run during which SCWO gas effluent sampling was carried out by AirKinetics, Inc., and also the run for which the Run Plan is given in Appendix A. As compared to Run 8.2, a slower ramp of TD temperature was used - about 5.5 hours to $1000^{\circ} \mathrm{F}$, followed by a 1 -hr hold time at $1000^{\circ} \mathrm{F}$. The maximum reactor temperature was held at nearly $1400^{\circ} \mathrm{F}\left(750^{\circ} \mathrm{C}\right)$. The lower plot in Figure 10 shows only a single protracted episode of high volatiles desorption as the TD temperature increases from about $660^{\circ} \mathrm{F}\left(350^{\circ} \mathrm{C}\right)$ to $930^{\circ} \mathrm{F}\left(500^{\circ} \mathrm{C}\right)$. The slower rate of change of volatiles desorption makes control of the SCWO reactor easier, and operation is smooth with temperatures above $1100^{\circ} \mathrm{F}\left(600^{\circ} \mathrm{C}\right)$ the entire time.

During the high volatiles desorption period, the $\mathrm{CO}$ level is seen to rise notably in Figure 10, signifying a short period of incomplete oxidation. When the results of the AirKinetics gas sampling analysis were received, the measured levels for carbon tetrachloride $\left(\mathrm{CCl}_{4}\right)$ and perchloroethylene $\left(\mathrm{C}_{2} \mathrm{Cl}_{4}\right)$ were higher than expected, and likely due to inadequate time at temperature. Slightly higher SCWO temperatures are therefore needed to insure complete destruction of chlorinated compounds.

\section{Surrogate Recipe \#3, $1470^{\circ} \mathrm{F}$ SCWO Temperature}

Figure 11 shows key data for Run 11.0, which utilized recipe \#3. The ramp of TD temperature was essentially the same as that used during Run 10.1. In addition to using the recipe with the highest volatile content, this run utilized a maximum SCWO reactor temperature of about $1470^{\circ} \mathrm{F}\left(800^{\circ} \mathrm{C}\right)$. The higher reactor temperature had a significant effect on lowering gas effluent $\mathrm{CO}$ levels, with an average of $12 \mathrm{ppm}$ over the course of the desorption.

\section{Surrogate Recipe \#1, $1540^{\circ} \mathrm{F}$ SCWO Temperature}

Figure 12 shows key data for Run 12.1, which utilized recipe \#1. This was the final run of the Phase I program, and was carried out for the site visit from DOE representatives. The ramp of TD temperature was essentially the same as that used during Runs 10.1 and 11.0. This run utilized a maximum SCWO reactor temperature of about $1540^{\circ} \mathrm{F}\left(840^{\circ} \mathrm{C}\right)$, and gas effluent CO was now near zero for the entire desorption period. 

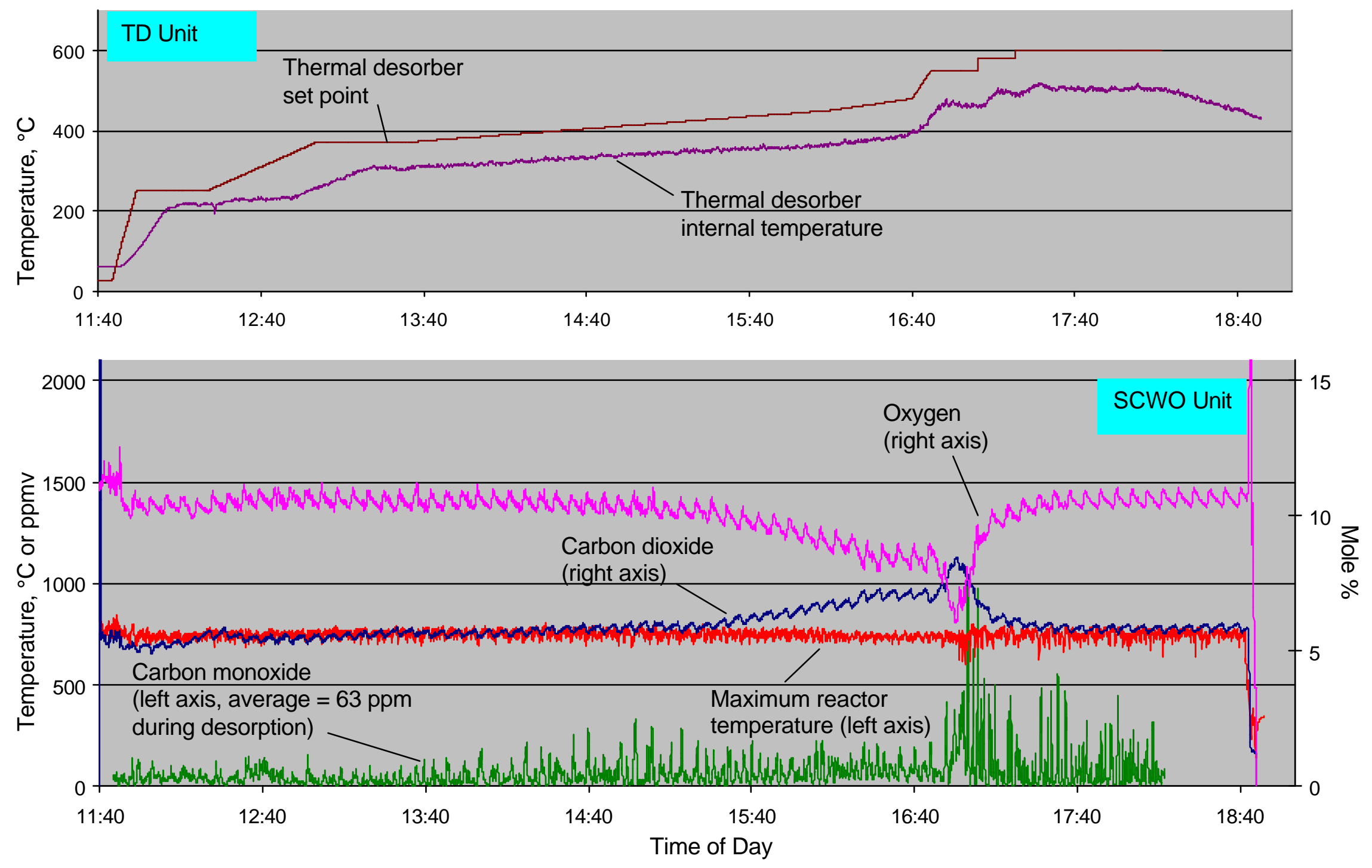

Figure 10. Plots for Run 10.1, recipe \#1. 

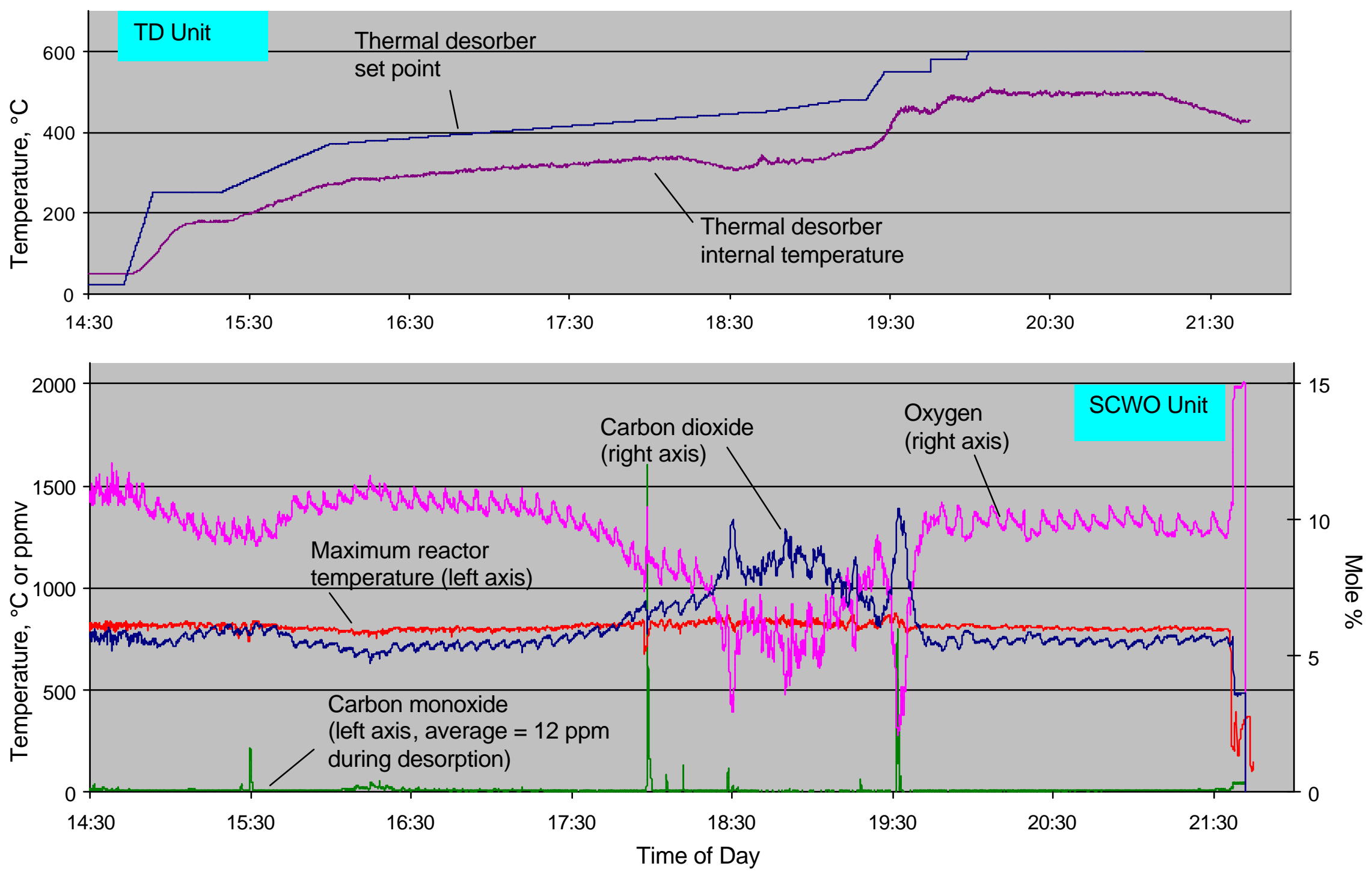

Figure 11. Plots for Run 11.0, recipe \#3. 

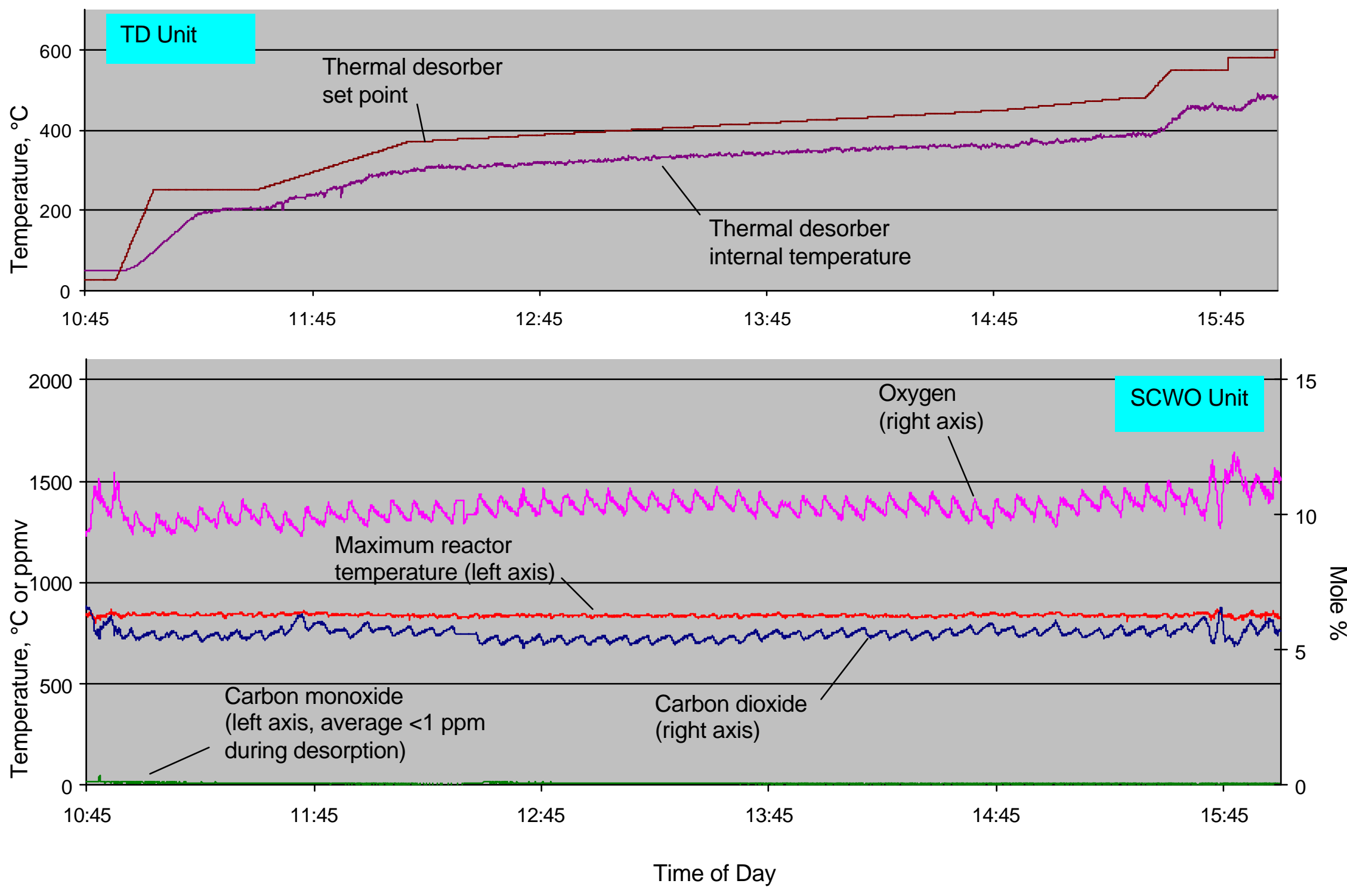

Figure 12. Plots for Run 12.1, recipe \#1. 
Figure 13 shows the appearance of the materials used to make up a single canister charge for recipe \#2.

Leaded gloves
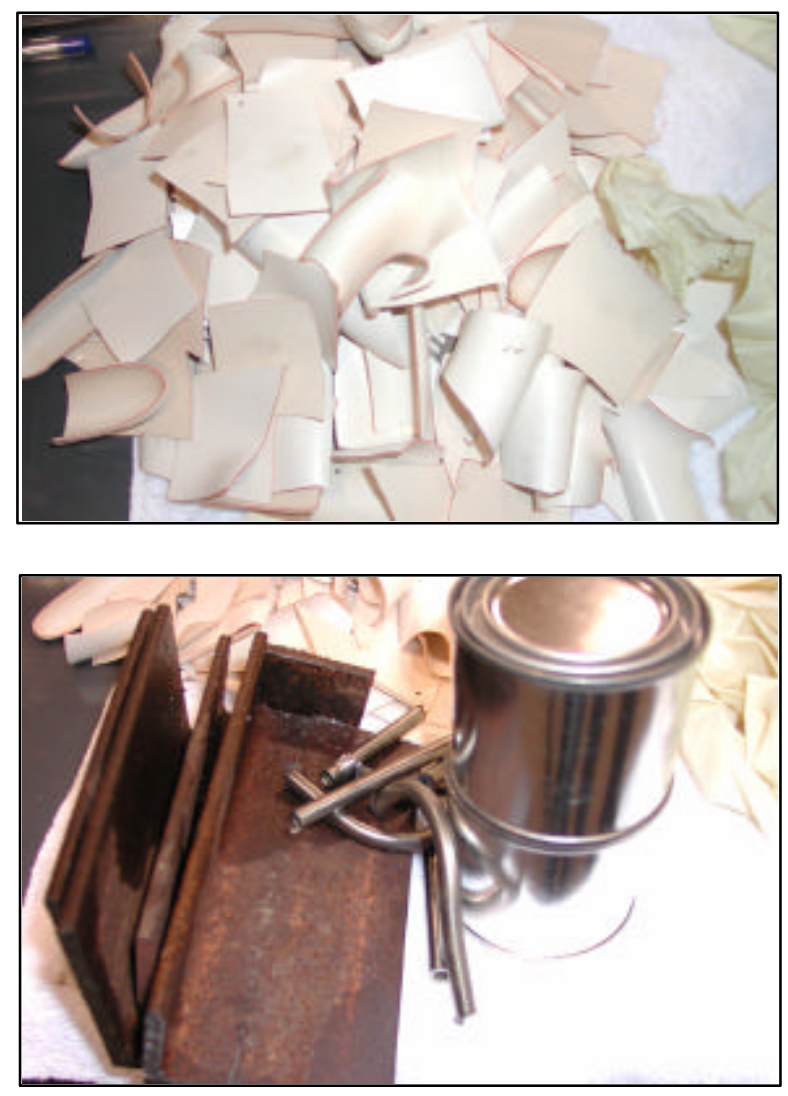

Metal parts
Latex gloves
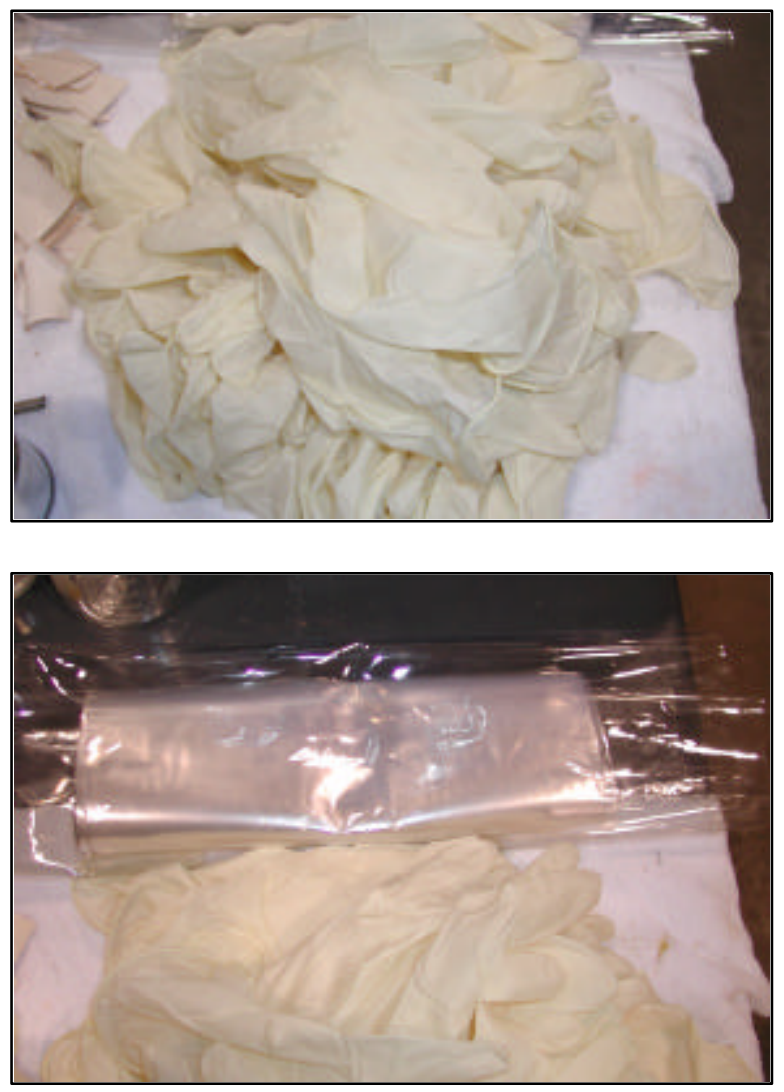

PVC sheet

Figure 13. Ingredients for recipe \#2.

Figure 14 shows the appearance of the recipe \#2 materials after desorption. As shown in the photo, closed cans were typically deformed and had their lids disrupted. Residue from leaded gloves appeared as a charred version of the original material. Lead was originally present in the gloves as a red-orange layer signifying red lead oxide. Red lead oxide decomposes to metal at $500^{\circ} \mathrm{C}$, however there were no indications of any molten lead metal. In addition, the residues contained low residual moisture. This is important because even inorganic hydrogen, e.g. in the form of water, can contribute to hydrogen generation in the actual radioactive waste.

Figure 15 provides a comparison of the desorbed material entering the SCWO unit with the liquid leaving the SCWO unit. This is an indication of the very clean effluents that are produced by the SCWO process. It should be noted that the condensate materials shown in Figure 15 are not normally observed during the TD-SCWO process, as they are generated in the TD unit and proceed directly to the SCWO unit. The condensate photos shown are of material collected from a TD-only test. As shown in the figure, some of the TD condensate is thick and tarry at room temperature. 


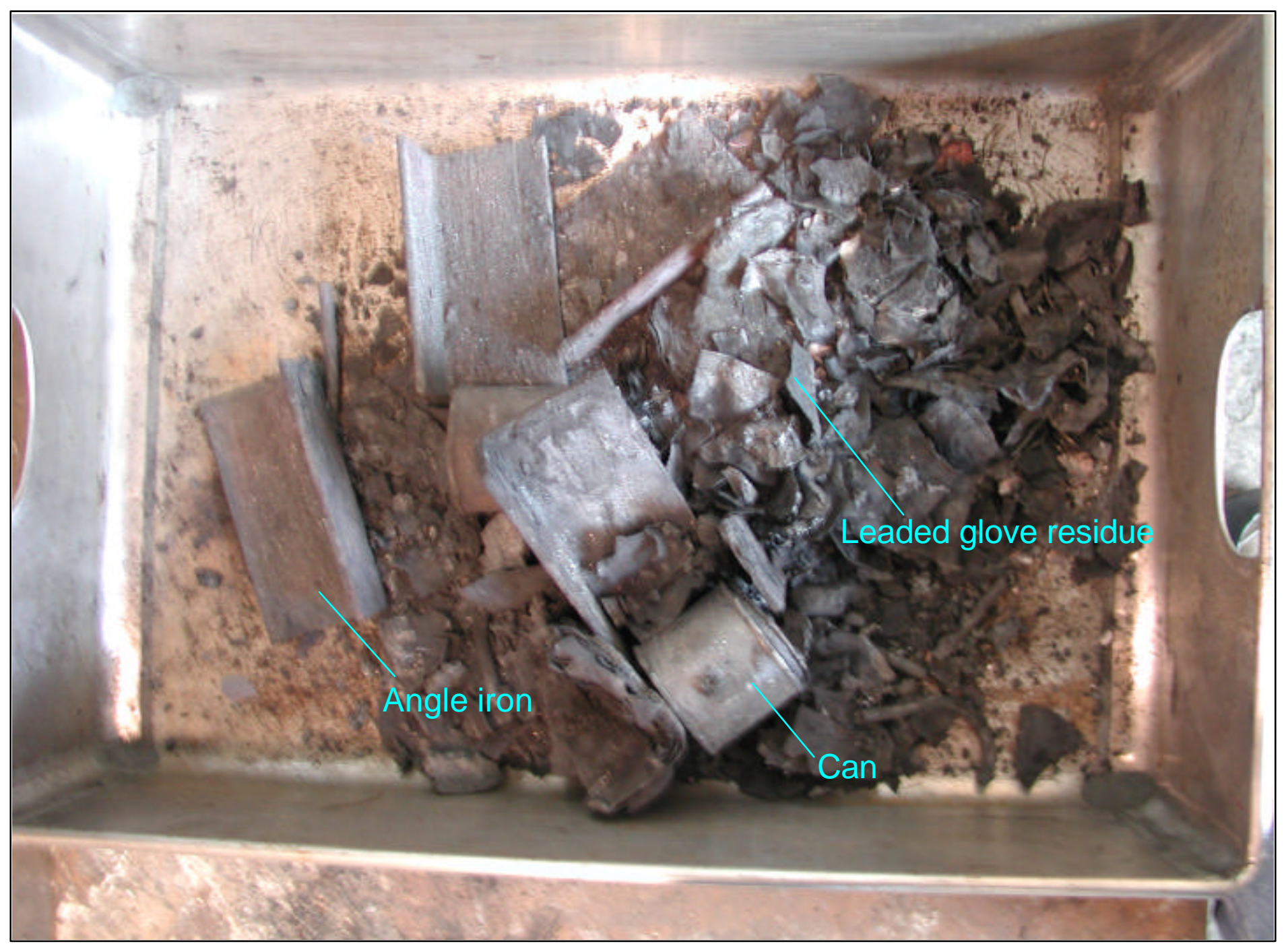

Figure 14. Residue from a run with recipe \#2. 


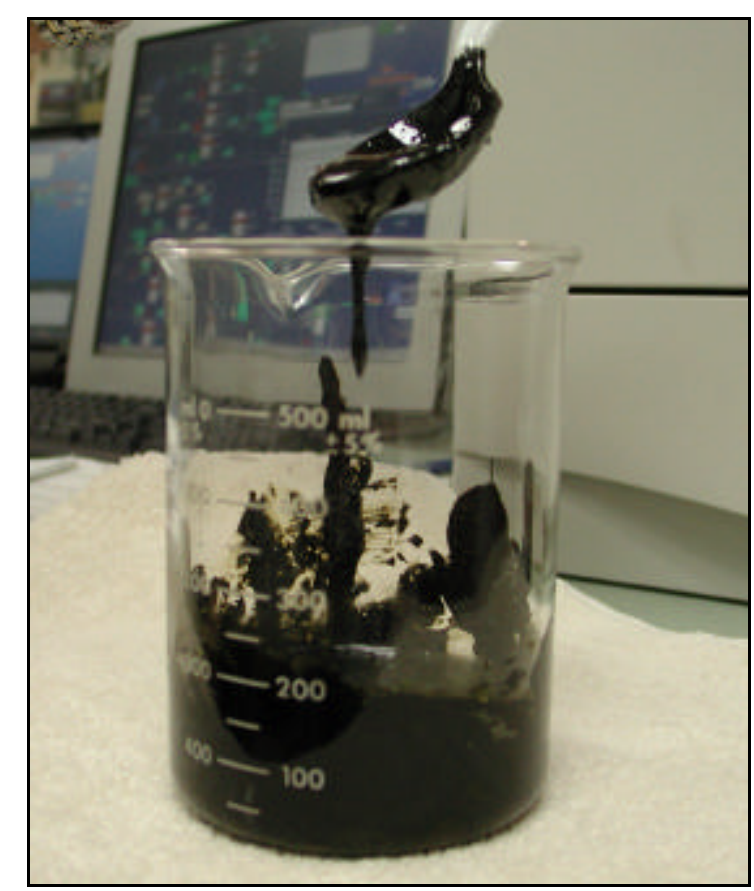

Tarry TD Condensate

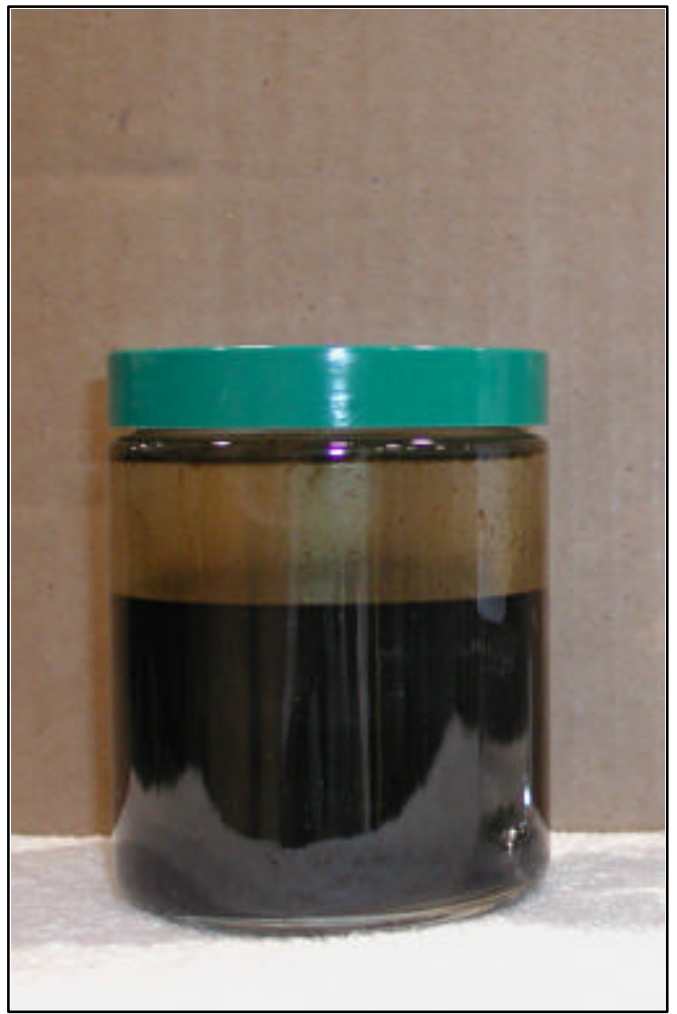

Liquid TD Condensate

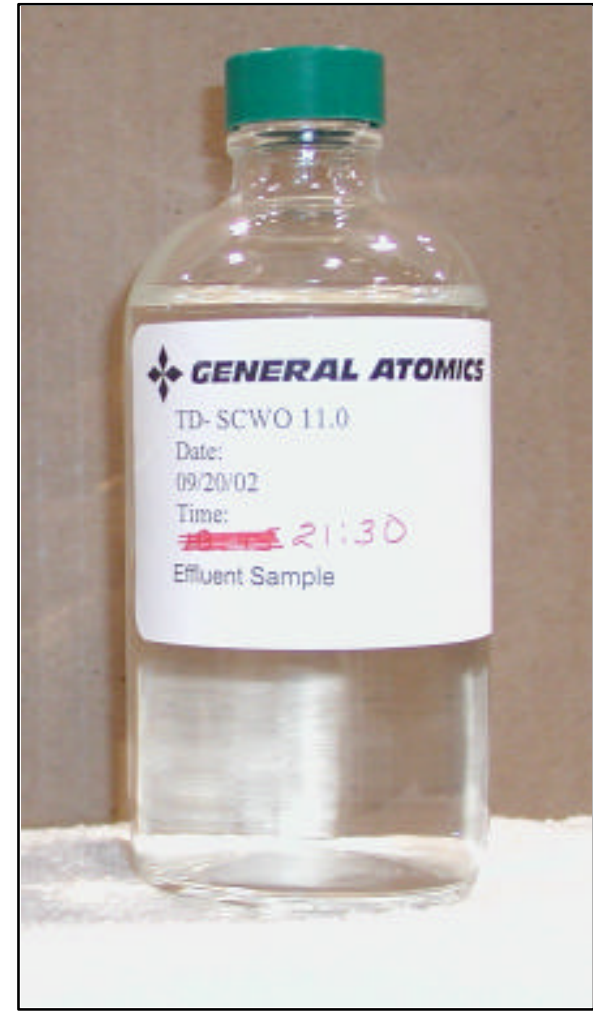

SCWO Effluent

Figure 15. Comparison of materials entering and leaving the SCWO unit. 


\subsection{Analytical Results}

Ultimate analysis of TD solid residues was carried out by Hazen Research, Inc., Golden, CO. The main purpose of this analysis was to determine residual hydrogen in the residue. Ultimate analysis was carried out on many TD-only runs as well most of the TD-SCWO runs. The results for the TD-SCWO testing are given in Table 3. As was shown in Figure 14, it was still possible in many cases to identify which residues had come from which starting materials. Since homogenization of entire batches would have been very difficult, several different samples were usually analyzed to determine the range of hydrogen content. As seen in the table, residual hydrogen ranged from $0.35 \%$ to $2.90 \%$. In Table 3, the entry "Paper/IPA" indicates paper towels soaked with isopropyl alcohol. The entry "Typical" indicates miscellaneous ash that could not be identified with a particular starting material. Also, oxygen content was determined by difference. The can crystals found in Run 7.0 are of unknown composition, but contain high moisture content that may have been picked up from the atmosphere.

Table 3. Ultimate Analysis Results for TD Solids

\begin{tabular}{|c|c|c|c|c|c|c|c|c|c|}
\hline \multirow{2}{*}{$\begin{array}{c}\text { TD- } \\
\text { SCWO } \\
\text { Run }\end{array}$} & \multirow{2}{*}{$\begin{array}{l}\text { Feed } \\
\text { Recipe }\end{array}$} & \multirow{2}{*}{ Sample } & \multicolumn{7}{|c|}{$\mathbf{W t} \%$} \\
\hline & & & Moisture & Ash & S & C & H & $\mathbf{N}$ & 0 \\
\hline \multirow[t]{3}{*}{5.0} & \#3 & HEPA & 4.97 & 20.50 & 0.09 & 72.40 & 1.34 & 1.63 & $<0.01$ \\
\hline & & Paper/IPA & 10.99 & 9.46 & 0.11 & 78.13 & 0.84 & 0.16 & 0.31 \\
\hline & & Typical & 2.45 & 90.58 & 0.03 & 5.29 & 0.46 & 0.02 & 1.17 \\
\hline \multirow[t]{4}{*}{6.0} & $\# 1$ & Wood & 5.13 & 1.79 & 0.02 & 92.26 & 1.44 & 0.23 & $<0.01$ \\
\hline & & PVC & 3.91 & 7.91 & 0.05 & 87.07 & 1.94 & 0.11 & $<0.01$ \\
\hline & & Paper & 6.05 & 7.87 & 0.10 & 79.81 & 1.69 & 0.20 & 4.28 \\
\hline & & Typical & 4.83 & 12.70 & 0.04 & 79.63 & 1.85 & 0.06 & 0.89 \\
\hline \multirow[t]{4}{*}{7.0} & \#2 & Bottom & 0.94 & 24.89 & 0.47 & 37.40 & 0.80 & 0.03 & 35.47 \\
\hline & & PVC & 2.68 & 6.97 & 0.10 & 80.18 & 1.52 & 0.12 & 8.43 \\
\hline & & Can crystals & 13.87 & 24.89 & 0.19 & 40.50 & 0.79 & 0.01 & 19.75 \\
\hline & & Polypropylene & 3.40 & 14.05 & 0.22 & 80.65 & 1.42 & 0.11 & 0.15 \\
\hline \multirow[t]{3}{*}{8.2} & \#2 & Typical & 0.58 & 27.54 & 0.35 & 15.92 & 0.44 & $<0.01$ & 55.17 \\
\hline & & Leaded glove & 0.45 & 24.56 & 0.42 & 11.68 & 0.35 & $<0.01$ & 62.54 \\
\hline & & PVC & 1.22 & 16.23 & 0.23 & 37.76 & 0.86 & 0.02 & 43.68 \\
\hline \multirow[t]{3}{*}{9.3} & \#3 & Typical & 0.72 & 91.12 & 0.06 & 5.23 & 1.71 & $<0.01$ & 1.16 \\
\hline & & HEPA & 2.82 & 81.47 & 0.21 & 6.37 & 1.09 & $<0.01$ & 8.04 \\
\hline & & Paper/IPA & 1.19 & 10.75 & 0.10 & 85.24 & 2.90 & 0.08 & $<0.01$ \\
\hline \multirow[t]{4}{*}{10.1} & \#1 & Paper & 3.60 & 5.73 & 0.03 & 86.87 & 2.03 & 0.26 & 1.48 \\
\hline & & PVC & 3.08 & 8.50 & 0.03 & 86.33 & 1.97 & 0.14 & $<0.01$ \\
\hline & & Typical & 2.18 & 79.82 & 0.06 & 15.27 & 0.55 & 0.04 & 2.08 \\
\hline & & Wood & 2.35 & 4.35 & $<0.01$ & 88.42 & 2.42 & 0.25 & 2.21 \\
\hline \multirow[t]{5}{*}{11.0} & \#3 & Paper/IPA & 5.57 & 6.49 & 0.05 & 82.56 & 1.86 & 0.35 & 3.12 \\
\hline & & HEPA & 6.20 & 74.99 & 0.05 & 11.49 & 0.36 & 0.15 & 6.76 \\
\hline & & PVC & 2.69 & 21.75 & 0.03 & 75.17 & 1.75 & 0.11 & $<0.01$ \\
\hline & & Typical & 1.35 & 85.62 & 0.04 & 11.20 & 0.79 & 0.04 & 0.95 \\
\hline & & Wood & 0.64 & 4.39 & 0.05 & 91.51 & 2.62 & 0.21 & 0.58 \\
\hline \multirow[t]{3}{*}{12.0} & $\# 1$ & Paper & 5.07 & 5.05 & 0.03 & 83.19 & 1.76 & 0.32 & 4.58 \\
\hline & & PVC & 2.62 & 8.18 & 0.05 & 86.89 & 2.12 & 0.16 & $<0.01$ \\
\hline & & Typical & 1.16 & 80.32 & 0.05 & 16.15 & 0.78 & 0.01 & 1.53 \\
\hline
\end{tabular}


The ultimate analysis shows that residual moisture content varies from less than $1 \%$ to a high of nearly $14 \%$. It should be noted that samples were not sealed and some residual moisture may have been picked up from the atmosphere.

Cerium was measured in solid residue and TD condensate in two TD-only runs. These are shown in Table 4. Cerium oxide was originally distributed throughout the canister charge. Subsequent to desorption, cerium was only detected in the residual solids at the bottom of the canister. No cerium was found in the small deposits located on the upper canister walls or vessel walls. Most importantly, no cerium was found in the TD condensate, indicating that no cerium would make its way to the SCWO unit. There was no attempt to account for all the cerium that was originally added to the canister as this would have involved very lengthy sample collection and analysis procedures due to the heterogeneity of the canister residue. While plutonium will not necessarily behave identically to the cerium surrogate, the cerium results nevertheless provide a positive indication for retention of plutonium in the waste drums.

Table 4. Cerium Analysis Results for TD Solids and Condensate

\begin{tabular}{|c|c|c|}
\hline TD Run: & $\# \mathbf{1 7}$ & $\# \mathbf{1 8}$ \\
\hline Feed recipe & $\# 3$ & $\# 1$ \\
\hline Ce in solids from inside bottom of canister & $10 \mathrm{mg} / \mathrm{kg}$ & Not analyzed \\
\hline Ce in solids from inside top of canister & $<16 \mathrm{mg} / \mathrm{kg}^{*}$ & Not analyzed \\
\hline Ce in solids from canister OD & $<2.1 \mathrm{mg} / \mathrm{kg}$ & No solid present \\
\hline Ce in solids from vessel wall above canister & $<1.8 \mathrm{mg} / \mathrm{kg}$ & $<9.3 \mathrm{mg} / \mathrm{kg}$ \\
\hline Ce in condensate liquid (TD only) & $<0.20 \mathrm{mg} / \mathrm{L}$ & $<0.20 \mathrm{mg} / \mathrm{L}$ \\
\hline
\end{tabular}

${ }^{*}<$ indicates nondetectable

The SCWO liquid effluent was analyzed to confirm the immobility of cerium, to check for lead carryover, and to assess organic destruction. These analyses, carried out by Alpha Analytical Labs in Westborough, MA, are shown in Table 5. The "Sample" column shows at what time a particular grab sample was taken. Each sample was analyzed for only one analyte. As expected from the TD condensate results, cerium was nondetectable in the SCWO effluent. Lead was detected at a low level, well below the TCLP limit of $0.75 \mathrm{ppm}$. Total organic carbon (TOC) results were comparable to those observed with conventional SCWO at 3400 psi, i.e., in the range of $1 \mathrm{ppm}$.

Table 5. Analytical Results for SCWO Liquid Effluent

\begin{tabular}{|c|c|c|c|c|c|}
\hline TD-SCWO Run & Feed Recipe & Sample & $\mathbf{C e}, \mathbf{~} \mathbf{g} / \mathbf{L}^{*}$ & $\mathbf{P b}, \mathbf{~ m g} / \mathbf{L}$ & $\mathbf{T O C}, \mathbf{~ m g} / \mathbf{L}$ \\
\hline \multirow{2}{*}{8.2} & \multirow{2}{*}{$\# 2$} & $12: 15$ & & & 1.2 \\
\cline { 3 - 6 } & & $12: 30$ & & 0.035 & \\
\cline { 3 - 6 } & \multirow{2}{*}{10.1} & $12: 45$ & $<0.10$ & & 1.3 \\
\cline { 3 - 6 } & \multirow{2}{*}{11.0} & $17: 00$ & & & 1.3 \\
\hline \multirow{2}{*}{12.0} & \multirow{2}{*}{$\# 1$} & $19: 30$ & $<0.10$ & & 1.0 \\
\cline { 3 - 6 } & & $15: 15$ & $<0.10$ & & \\
\cline { 3 - 6 } & & $15: 30$ & $<0.10$ & & \\
\hline
\end{tabular}

${ }^{*}<$ indicates nondetectable 
As previously mentioned, the SCWO gas effluent was analyzed for key target species during Run 10.1. Samples were collected and analyzed by AirKinetics, Inc. of Huntington Beach, CA. Table 6 provides a summary of these results. The gas analyses will be further discussed below in the context of the test success criteria.

Table 6. Analytical Results for SCWO Gas Effluent

\begin{tabular}{|c|c|c|c|}
\hline Analyte & Sampling Time & Units & Results \\
\hline Particulates & $12: 50-17: 48$ & $\mathrm{mg} / \mathrm{dscm}$ & $0.105\left(=5 \times 10^{-5}\right.$ grains $\left./ \mathrm{dscf}\right)$ \\
\hline Total PCDDs & \multirow{3}{*}{$11: 47-17: 47$} & \multirow{3}{*}{$\mathrm{ng} / \mathrm{dscm}$} & $\begin{array}{c}0.00489 \\
(\text { No } 2,3,7,8 \text { isomers, } T E Q=0)^{\star}\end{array}$ \\
\hline Total PCDFs & & & $\begin{array}{c}0.0192 \\
\text { (No 2,3,7,8 isomers, TEQ }=0 \text { ) }\end{array}$ \\
\hline Total PCDDS and PCDFs & & & $\begin{array}{c}0.0240 \\
\text { (No 2,3,7,8 isomers, TEQ }=0 \text { ) }\end{array}$ \\
\hline Antimony & \multirow{8}{*}{$12: 50-17: 48$} & \multirow{8}{*}{ ìg/dscm } & 0.0131 \\
\hline Arsenic & & & $\mathrm{ND}(<0.565)$ \\
\hline Beryllium & & & $\mathrm{ND}(<0.283)$ \\
\hline Cadmium & & & 0.0216 \\
\hline Chromium & & & $\mathrm{ND}(<0.565)$ \\
\hline Cerium & & & $\mathrm{ND}(<1.40)$ \\
\hline Lead & & & 0.148 \\
\hline Mercury & & & 0.158 \\
\hline Carbon tetrachloride & \multirow{2}{*}{$12: 50-13: 50$} & \multirow{2}{*}{ ppbvd } & 60 \\
\hline Perchloroethylene & & & 68 \\
\hline
\end{tabular}

${ }^{*}$ Ref. 3

\subsection{Success Criteria}

Success of the demonstration tests was measured by (1) attainment of hydrogen reduction goals, (2) meeting environmental criteria for processed waste and effluents, and (3) equipment operability at the specified conditions. Specific success criteria for the Phase I Cold Demonstration tests are defined in Table 7, along with the status based on results from the Phase I testing.

The TD-SCWO process met all success criteria with the exception of demonstrating $>99.99 \%$ destruction and removal efficiency of carbon tetrachloride and perchloroethylene. Assuming the sample of Table 6 captured the bulk of the desorption peak of these compounds, as intended, a DRE of about $99.9 \%$ for each is calculated. This result is attributed to a low SCWO temperature during the gas sampling test (Run 10.1). A number of studies have shown that SCWO can attain $>99.99 \%$ destruction of highly refractory chlorinated organics such as PCBs (Ref. 4) and hexachlorobenzene (unpublished GA/Modar data). Carbon monoxide is one of the more 
Table 7. Success Criteria

\begin{tabular}{|c|c|c|}
\hline Requirement & Success Criteria & Status \\
\hline Nonincineration & $\begin{array}{l}\text { Peak process temperature measured via } \\
\text { thermocouple to be }<1600^{\circ} \mathrm{F}\left(871^{\circ} \mathrm{C}\right)\end{array}$ & $\begin{array}{c}\text { Demonstrated, } \\
\text { see Figures } 9-12 \\
\end{array}$ \\
\hline Hydrogen Removal & Total hydrogenous organic in residue $<5 \mathrm{wt} \%$ & $\begin{array}{l}\text { Demonstrated, } \\
\text { see Table } 8\end{array}$ \\
\hline $\begin{array}{l}\text { Destruction and } \\
\text { Removal Efficiency }\end{array}$ & $\begin{array}{l}\text { Spiked constituents }\left(\mathrm{CCl}_{4} \text { and } \mathrm{C}_{2} \mathrm{Cl}_{4}\right) \text { measured in } \\
\text { gaseous effluent to verify compliance with }>99.99 \% \\
\text { destruction and removal }\end{array}$ & $\begin{array}{l}\text { Demonstrated } \\
\sim 99.9 \% \text { DRE }\end{array}$ \\
\hline $\mathrm{CO}$ & CO level in gaseous effluent verified to be $<100 \mathrm{ppm}$ & $\begin{array}{l}\text { Demonstrated, } \\
\text { see Figures } 10-12\end{array}$ \\
\hline $\begin{array}{l}\text { Particulate } \\
\text { Emissions }\end{array}$ & $\begin{array}{l}\text { Particulate level in gaseous effluent verified to be } \\
<0.015 \text { grains/dscf }\end{array}$ & $\begin{array}{l}\text { Demonstrated, } \\
\text { see Table } 6\end{array}$ \\
\hline Mercury Removal & $\begin{array}{l}\text { Hg level in gaseous effluent verified to be }<45 \\
\mu \mathrm{g} / \mathrm{dscm}\end{array}$ & $\begin{array}{l}\text { Demonstrated, } \\
\text { see Table } 6 \text { (no } \\
\text { Hg added to feed) }\end{array}$ \\
\hline $\begin{array}{l}\text { Cadmium and Lead } \\
\text { Removal }\end{array}$ & $\begin{array}{l}\mathrm{Cd}+\mathrm{Pb} \text { level in gaseous effluent verified to be } \\
<0.024 \mathrm{mg} / \mathrm{dscm}\end{array}$ & $\begin{array}{l}\text { Demonstrated, } \\
\text { see Table } 6\end{array}$ \\
\hline $\begin{array}{l}\text { Antimony, Arsenic, } \\
\text { Beryllium, and } \\
\text { Chromium Removal }\end{array}$ & $\begin{array}{l}\mathrm{Sb}+\mathrm{As}+\mathrm{Be}+\mathrm{Cr} \text { level in gaseous effluent verified } \\
\text { to be }<0.097 \mathrm{mg} / \mathrm{dscm}\end{array}$ & $\begin{array}{l}\text { Demonstrated, } \\
\text { see Table } 6\end{array}$ \\
\hline $\begin{array}{l}\text { Radioactive Particle } \\
\text { Containment }\end{array}$ & $\begin{array}{l}\text { Measure } \mathrm{CeO}_{2} \text { levels in gaseous and liquid effluent } \\
\text { to determine degree of containment }\end{array}$ & $\begin{array}{l}\text { Demonstrated, } \\
\text { see Tables 4-6 }\end{array}$ \\
\hline $\begin{array}{l}\text { Minimum } \\
\text { Pretreatment }\end{array}$ & $\begin{array}{l}\text { Minimum pretreatment requirements relative to other } \\
\text { technologies }\end{array}$ & Demonstrated \\
\hline $\begin{array}{l}\text { Minimum } \\
\text { Posttreatment } \\
\end{array}$ & $\begin{array}{l}\text { Minimum posttreatment gas cleaning process } \\
\text { relative to other technologies }\end{array}$ & Demonstrated \\
\hline $\begin{array}{l}\text { Dioxin/Furan } \\
\text { Emissions }\end{array}$ & $\begin{array}{l}\text { Total dioxins and furans in gaseous effluent verified } \\
\text { to be less than regulated levels of } 0.2 \mathrm{ng} / \mathrm{dscm} \\
\text { (TEQ) at } 7 \% \mathrm{O}_{2}\end{array}$ & $\begin{array}{l}\text { Demonstrated, } \\
\text { see Table } 6\end{array}$ \\
\hline WIPP/WAC & Meets requirements & $\begin{array}{l}\text { Demonstrated, } \\
\text { see Table } 9\end{array}$ \\
\hline TRUPACT-II & Meets requirements & $\begin{array}{l}\text { Demonstrated, } \\
\text { see Table } 9\end{array}$ \\
\hline
\end{tabular}

refractory compounds with regard to oxidation, and is a good general indicator of the completeness of reaction. When the SCWO reactor temperature is sufficiently high, CO levels will normally be less than a few ppm. As seen in Figure 10, this was not the case during Run 10.1, when the AirKinetics sampling was carried out and the maximum reactor temperature was only about $1400^{\circ} \mathrm{F}\left(750^{\circ} \mathrm{C}\right)$. In contrast, for Run 12.1 (Figure 12) with a maximum SCWO reactor temperature of about $1540^{\circ} \mathrm{F}\left(840^{\circ} \mathrm{C}\right), \mathrm{CO}$ is near zero as expected for good SCWO operation. Based on prior SCWO data as well as the low CO level, it is likely that the $>99.99 \%$ DRE criterion for the chlorinated solvents was met in Run 12.1. However, the Phase I program plan had allowance for only a single gas sampling event and gas analyses were not carried out for Run 12.1. Additional analyses for chlorinated hydrocarbons will be carried out in Phase III to demonstrate satisfactory DREs. 
As seen in Table 7, the requirement for hydrogen removal was framed in terms of "hydrogenous organic". This criterion is believed to address the shipping requirement that a container headspace should not comprise more than $5 \%$ of flammable gases including hydrogen. However, different organic constituents can contain widely differing hydrogen contents. Furthermore, gaseous hydrogen can be produced from inorganic sources (including water) as well as organic sources. As an indicator of the effectiveness of TD-SCWO for hydrogen removal, calculations were carried out to show that the hydrogen in the TD residues was equivalent to a polyethylene content of less than $5 \mathrm{wt} \%$. These calculations are shown in Table 8 for one run with each recipe. From the measured mass of a residue, the mass of nonvolatile inorganics (e.g. metal parts, fiberglass from HEPA filters, oil-dry) was subtracted. This gave a residual quantity of char as shown in line 8 of the table. To be conservative, this char was assigned the maximum of the several hydrogen contents that had been determined by ultimate analysis (see Table 3), resulting in a residual hydrogen content as shown in line 10 of the table. This residual hydrogen was converted to a percent of the original mass (line 11) and finally expressed in terms of polyethylene $\left(\mathrm{CH}_{2}\right)$ equivalent (line 12). On this basis the hydrogen reduction meets the stipulated success criterion of less than $5 \%$ hydrogenous organic. As another measure of the treatment effectiveness, line 13 shows the factor by which hydrogen level has been reduced by the TD process. Finally, line 14 gives the factor by which the residual hydrogenous organic level bettered the required level of $5 \%$ (5\% divided by line 12 ).

Table 8. Determination of Hydrogenous Organic

\begin{tabular}{|c|l|c|c|c|}
\hline & \multicolumn{1}{|c|}{ TD-SCWO Run: } & Run 12.0 & Run 8.2 & Run 9.3 \\
\hline & Feed Recipe & $\# 1$ & $\# 2$ & $\# 3$ \\
\hline 1 & Initial mass in recipe, g & 802 & 3496 & 2509 \\
\hline 2 & Nonvolatiles in recipe, g & 136 & 2331 & 856 \\
\hline 3 & Organics in recipe, g & 666 & 1165 & 1653 \\
\hline 4 & Hydrogen in recipe, g & 50 & 61 & 203 \\
\hline 5 & Allowable organic after treatment $(5 \%), g$ & 40.1 & 175 & 125 \\
\hline 6 & Allowable H after treatment $\left(\right.$ as $\left._{\mathrm{CH}_{2}}\right), \mathrm{g}$ & 5.7 & 25 & 17.9 \\
\hline 7 & Total residue, g & 245 & 2900 & 875 \\
\hline 8 & Char residue, g & 109 & 569 & 19 \\
\hline 9 & Measured max H\% in char residue & 2.12 & 0.86 & 2.9 \\
\hline 10 & Residual $\mathrm{H}$ calculated, g & 2.3 & 4.89 & 0.54 \\
\hline 11 & Final \%H based on initial mass & 0.3 & 0.14 & 0.02 \\
\hline 12 & Final \%CH $\mathrm{C}_{2}$ equivalent (to be $\left.<5 \%\right)$ & 2.0 & 0.98 & 0.15 \\
\hline 13 & H reduction factor & 21 & 12 & 374 \\
\hline $\mathbf{1 4}$ & H reduction factor below $\mathbf{5 \%}$ & $\mathbf{2 . 5}$ & $\mathbf{5 . 1}$ & $\mathbf{3 3}$ \\
\hline
\end{tabular}

Table 7 calls for the TD residue to meet WIPP/WAC and TRUPACT-II requirements. Table 9 provides a detail of these requirements along with the status based on results from the Phase I testing. There do not appear to be any concerns in meeting all of these requirements. 
Table 9. WIPP/WAC and TRUPACT II Requirements

\begin{tabular}{|l|l|l|}
\hline \multicolumn{1}{|c|}{ Waste Type } & \multicolumn{1}{|c|}{ Waste Acceptance Criteria } & \multicolumn{1}{c|}{ TD-SCWO Phase I Results } \\
\hline Free liquids & $\begin{array}{l}\text { Less than 1 volume \% of external } \\
\text { container. Less than 1 inch in } \\
\text { bottom of internal containers. }\end{array}$ & $\begin{array}{l}\text { No free liquids observed in Phase I } \\
\text { residues. }\end{array}$ \\
\hline $\begin{array}{l}\text { Pyrophoric } \\
\text { materials }\end{array}$ & $\begin{array}{l}<1 \% \text { radionuclide pyrophorics. No } \\
\text { nonradioactive pyrophorics }\end{array}$ & $\begin{array}{l}\text { No pyrophoric materials observed } \\
\text { in Phase I residues. (None in } \\
\text { feed.) }\end{array}$ \\
\hline Sealed containers & $\begin{array}{l}\text { No sealed containers greater than 4 } \\
\text { liters }\end{array}$ & $\begin{array}{l}\text { Containers crushed and/or lids } \\
\text { separated in Phase I testing. }\end{array}$ \\
\hline Hazardous waste & $\begin{array}{l}\text { Limited to RCRA hazardous waste } \\
\text { codes that ensure no ignitable, } \\
\text { corrosive, or reactive characteristics }\end{array}$ & $\begin{array}{l}\text { Phase I residues are relatively inert } \\
\text { inorganics and char. }\end{array}$ \\
\hline $\begin{array}{l}\text { Explosives, } \\
\text { corrosives, and } \\
\text { compressed gases }\end{array}$ & $\begin{array}{l}\text { No explosives, corrosives, or } \\
\text { compressed gases }\end{array}$ & $\begin{array}{l}\text { No explosives, corrosives, or } \\
\text { compressed gases observed in } \\
\text { Phase I residues. (No explosives } \\
\text { or compressed gases in feed.) }\end{array}$ \\
\hline $\begin{array}{l}\text { Headspace gas } \\
\text { VOC } \\
\text { concentrations }\end{array}$ & $\begin{array}{l}\text { Every container will be headspace } \\
\text { gas sampled }\end{array}$ & $\begin{array}{l}\text { No residual VOCs observed in } \\
\text { Phase I residues. }\end{array}$ \\
\hline PCB concentration & <50 ppm & $\begin{array}{l}\text { Not tested in Phase I. High } \\
\text { temperature in TD will ensure that } \\
\text { no PCBs remain. }\end{array}$ \\
\hline $\begin{array}{l}\text { Test category } \\
\text { waste }\end{array}$ & $\begin{array}{l}\text { Steady-state hydrogen gas } \\
\text { generation rate is less than or equal } \\
\text { to the rate specified in the } \\
\text { TRUPACT-II Safety Analysis }\end{array}$ & $\begin{array}{l}\text { Phase I shows total hydrogenous } \\
\text { organic in residue <5 wt\%. } \\
\text { Typically <<5 wt\%. }\end{array}$ \\
\hline Flammable VOCs & $\begin{array}{l}<500 \text { ppm total in the headspace of } \\
\text { any payload container }\end{array}$ & $\begin{array}{l}\text { No flammable VOCs observed in } \\
\text { Phase I residues. }\end{array}$ \\
\hline
\end{tabular}

\section{CONCLUSION}

The findings of the Phase I testing are as follows:

- Thermal desorption of surrogate SRS mixed wastes at $500 \mathrm{psi}$ and $1000^{\circ} \mathrm{F}$ meets all tested requirements for WIPP/WAC and TRUPACT-II.

- SCWO of the desorbed surrogate organic materials at 500 psi and $1500^{\circ} \mathrm{F}$ appears to meet all requirements for a nonincineration alternative. DRE for chlorinated solvents was slightly less than required during the lower temperature SCWO tests, so this temperature should be maintained to insure destruction.

- Air oxidant is preferred over pure oxygen for SCWO to allow the use of a corrosionresistant titanium lining.

- TD-SCWO technology is ready to proceed to Phase III, the full-scale module cold demonstration.

Based on the results obtained during Phase I, TD-SCWO appears to represent a promising alternative to incineration of mixed radioactive wastes. Potential benefits for the application of TD-SCWO technology are discussed below. 
Low Life Cycle Costs. TD-SCWO will require less gas treatment technology than any known competitive technology due to the internal scrubbing achieved by SCWO. At most, a chiller, activated carbon and HEPA filters will be required to capture trace mercury and other trace contaminants. TD-SCWO is extremely compact, requiring a smaller footprint than any known competitive technology due to the higher throughput achieved at elevated pressure and smaller gas cleaning system. Reduced carryover of Pu-238 from the batch TD to SCWO may enable the SCWO system to be contact-maintained - a potentially significant advantage over competing technologies. For nonradioactive applications, GA has performed cost analyses that have generally compared favorably with incineration for the same waste feed.

Low Health and Safety Risks to the Worker and the Public. TD-SCWO is a sealed, pressurized system with the pressurized components enclosed by secondary containment and vented through HEPA filters and activated carbon. In the event of process upsets, relief valves open to discharge the system contents to a dump tank for reprocessing at a later date. All maintenance operations are performed on the depressurized system. Effluents are monitored continuously to ensure that they meet all regulatory standards. Leading indicators of process performance are also tracked by the process control computer system to provide ongoing assurance of operation within specification.

Low Risks for Detrimental Impact to the Environment. TD-SCWO is an inherently clean process that eliminates the conditions that lead to de novo synthesis of dioxins or furans. TDSCWO will minimize emissions of the metals and radionuclides that are currently in the drummed wastes by retaining most of these wastes in the TD, and capturing the remainder in the SCWO liquid effluent.

Low Quantity of Waste Materials Requiring Disposal. TD-SCWO will densify the wastes allowing repackaging into fewer drums for transport to WIPP. Solid effluents from SCWO (obtained by filtering and drying the SCWO liquid effluent) will generally be lower in volume than for any other technology, because TD-SCWO mineralizes all organic feeds to $\mathrm{CO}_{2}$, water, and mineral salts. This will maximize the volume reduction and minimize the resultant residues to be disposed.

Low Amount of Secondary Waste Generated. Because TD-SCWO does not produce dioxins or furans, no activated carbon is required to meet the stringent new Clean Air Maximum Achievable Control Technology (MACT) standards for dioxin and furan emissions. Mercury emissions will be collected on activated carbon filters (sulfur impregnated to fix the mercury in an insoluble form) and will be disposed of as a stabilized hazardous waste. TD-SCWO is expected to generate less secondary waste than competitive technologies. With the exception of mercury (mercury was not tested), metals including radionuclides and other particulates will be retained within the TD-SCWO system and will not add loading to the backup HEPA filters, thus reducing the frequency of replacement of these filters. Solids are discharged from the batch TD along with the other drum residues, and are filtered out of the SCWO liquid effluents for subsequent drying and disposal. Salts crystallized from SCWO liquid effluent (primarily $\mathrm{NaCl}$ from PVC processing) will be recombined with the main process solids discharge and repackaged for transport to WIPP. Here, again, TD-SCWO should produce less secondary waste than other competitive technologies because of the simpler gas cleaning process.

Low Hazard Level and Category of Waste. TD-SCWO will efficiently destroy all organic constituents in the waste. Metals (except mercury which was not tested) and radionuclides will be retained with the bulk desorbed waste and will be repackaged for disposal at WIPP. Mercury 
will be retained on sulfur-impregnated activated carbon for off-site disposal. Remaining metals may prevent the residue from meeting the Land Disposal Ban, as measured via Toxic Characteristic Leaching Procedure (TCLP) testing, and further stabilization may be required. Most importantly, TD-SCWO will not generate any dioxins or furans, which is less likely for competitive technologies which do not eliminate the conditions that lead to de novo synthesis of dioxins and furans.

Ability to Meet Regulatory Requirements. TD-SCWO inherently meets all regulatory criteria under the MACT rules. This includes destruction of organic compounds, retention of metals within the process, and all emissions within regulatory standards, including particulates, $\mathrm{HCl}$, $\mathrm{SO}_{\mathrm{x}}, \mathrm{NO}_{\mathrm{x}}$, and $\mathrm{CO}$, and again, dioxins and furans. Competitive technologies are less likely to meet all regulatory requirements without extensive additional pollution abatement equipment. RCRA permits have been obtained for three of GA's SCWO systems in record time, attesting to the degree to which the technology meets regulatory requirements.

\section{FULL-SCALE TD-SCWO MODULE}

Phase III involves the construction and cold-testing of a full-scale TD-SCWO module for the targeted SRS drummed wastes. The full-scale TD-SCWO module is sized to treat a 55-gal drum, including overpacked drums. Table 10 provides a comparison of some of the key design features of the existing pilot plant with the full-scale scale module, which represents a scale-up of 32x. Both systems use a single thermal desorber and cold-wall operation of the SCWO reactor. As shown in the table, the desorption heating cycle time for the full-scale scale module should be about the same as for the Phase 1 tests as both the quantity of organic and the SCWO reactor are scaled up by a factor of 32 .

For additional capacity, multiple 55-gallon TD modules can be added feeding a single SCWO system. The TD units would cycle between loading, operating, and unloading, alternately feeding the continuously operating SCWO unit. If necessary, active cooling can be used to decrease the turnaround time for the TD units. In this manner, with an 8-hr heatup/desorption time, a single full-scale SCWO unit can process 3 drums per day. For even greater capacity, multiple TD-SCWO modules may be installed.

Table 10. Comparison of TD-SCWO Pilot Plant and Full-Scale Module

\begin{tabular}{|l|c|c|}
\hline \multicolumn{1}{|c|}{ Design Parameter } & Pilot-Scale (existing) & Full-Scale Module \\
\hline Batch TD waste volume & 1.7 gallons & 55 gallons \\
\hline TD heating cycle time & 7 hours & $8-10 \mathrm{hours}$ \\
\hline Batch TD dimensions & $4 " \mathrm{ID} \times 5 \mathrm{ft}$ tall & $26^{\prime \prime} \mathrm{ID} \times 4 \mathrm{ft}$ tall \\
\hline SCWO reactor dimensions & $4 " \mathrm{ID} \times 5 \mathrm{ft}$ tall & $15^{\prime \prime} \mathrm{ID} \times 12 \mathrm{ft}$ tall \\
\hline SCWO heat release & $44,000 \mathrm{Btu} / \mathrm{hr}$ & $1.4 \mathrm{MMBtu} / \mathrm{hr}$ \\
\hline SCWO air demand & $40 \mathrm{lb} / \mathrm{hr}$ & $1300 \mathrm{lb} / \mathrm{hr}$ \\
\hline System pressure & $500 \mathrm{psig}$ & $500 \mathrm{psig}$ \\
\hline System temperature & $1000-1600^{\circ} \mathrm{F}$ & $1000-1600^{\circ} \mathrm{F}$ \\
\hline
\end{tabular}

Figure 16 shows a process flow diagram applicable to a full-scale TD-SCWO module. Figure 17 shows an architectural rendering of a full-scale TD-SCWO module facility. Drums will be accessed for TD by remote removal of a bung plug or the entire drum lid. The full-scale TDSCWO module control system will incorporate automated SCWO reactor temperature control to enhance ease of operation. If the low carryover of radionuclides suggested by the Phase I 
testing holds true, the SCWO system will be amenable to contact maintenance and operating costs will be significantly reduced.

\section{REFERENCES}

1. "Process for Oxidation of Materials in Water at Supercritical Temperatures and Subcritical Pressures", G.T. Hong, No. 5,106,513, April 21, 1992.

2. "Supplemental Hydrothermal Oxidation Development", General Atomics Project 3962 Final Report, June 1998.

3. "Test Methods for Evaluating Solid Waste", US EPA SW-846 Method 8280A rev. 1, 1996.

4. "The MODAR Supercritical Water Oxidation Process", T.B. Thomason, G.T. Hong, K.C. Swallow and W.R. Killilea, Innovative Hazardous Waste Treatment Technology Series, Thermal Processes, Vol. 1, pp 31-42, 1990. 


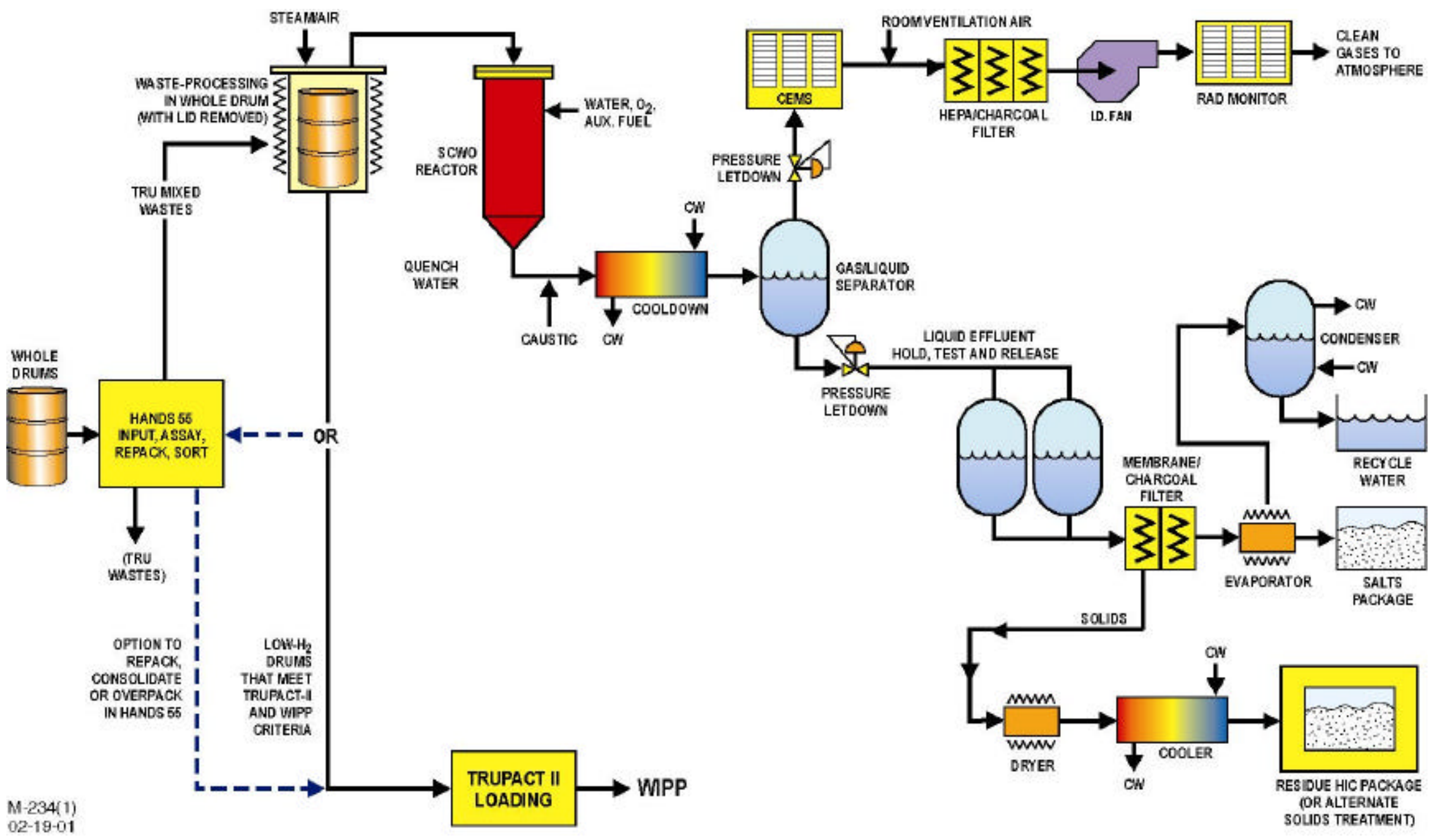

Figure 16. Process flow diagram for a full- scale TD-SCWO module. 


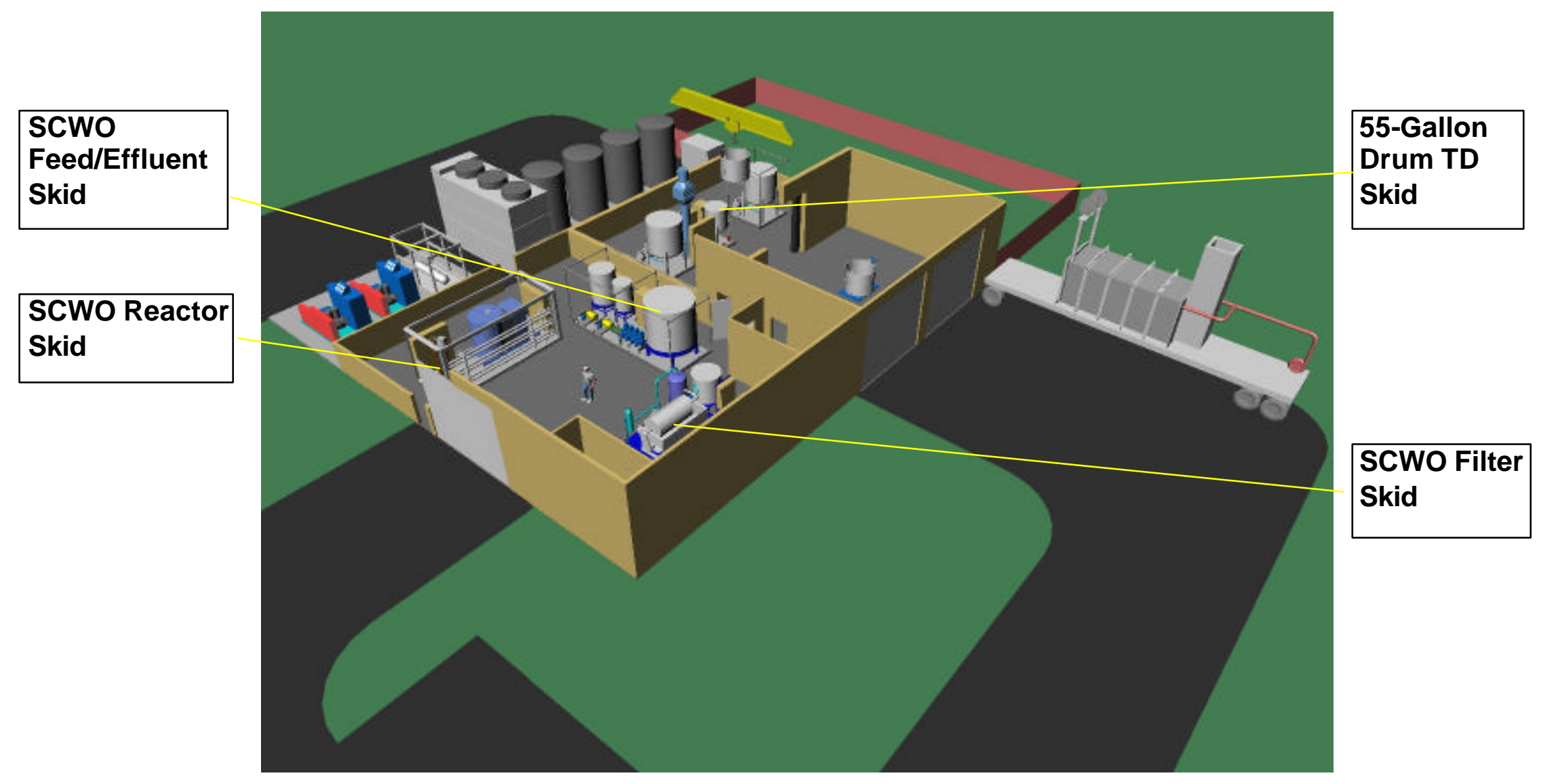

Figure 17. Architectural rendering of a full- scale TD-SCWO facility. 


\section{APPENDIX A. Sample TD-SCWO Run Plan}




\begin{tabular}{|l|l|}
\hline Run Number: & TDSCWO-10.1 \\
\hline Date: & 09/19/02 \\
\hline Project: & $\begin{array}{l}\text { TD SCWO - Thermal Desorption-Supercritical Water } \\
\text { Oxidation }\end{array}$ \\
\hline $\begin{array}{l}\text { Run } \\
\text { Description: }\end{array}$ & Recipe \#1 \\
\hline Approved: & \\
\hline Charge \# & 30117300 \\
\hline
\end{tabular}

\section{Objectives}

- Volatilize organics in the thermal desorber (TD) and oxidize in SCWO unit at 500 psi.

- No quench flow to minimize CO spikes.

- Gas sampling to be carried out by AirKinetics.

\section{Test Conditions}

\begin{tabular}{|l|l|}
\hline $\begin{array}{l}\text { Feed and feed } \\
\text { concentration }\end{array}$ & Hot gases from desorber \\
\hline Feed flowrate est. & $30 \mathrm{~g}$ organic/min peak $+65 \mathrm{~g} / \mathrm{min}$ of TD nitrogen purge \\
\hline Feed temperature & $<500^{\circ} \mathrm{C}$ \\
\hline Process water flowrate & $130 \mathrm{~g} / \mathrm{min}$ through Ohmic heater from P-300 \\
\hline Dilution water flowrate & $\begin{array}{l}\text { As required to maintain reactor temp }\left(650-700^{\circ} \mathrm{C}\right) . \text { From P- } \\
100 \text { to nozzle core. }\end{array}$ \\
\hline Fuel & Diesel \\
\hline Fuel flowrate & $\begin{array}{l}\sim 5 \text { to } 10 \mathrm{~g} / \mathrm{min}, \text { adjust to achieve reactor at } 650^{\circ} \mathrm{C} \text { with } \\
\text { minimum flow from P-100. }\end{array}$ \\
\hline $\begin{array}{l}\text { Vessel reactor } \\
\text { temperature }\end{array}$ & $650^{\circ} \mathrm{C}(\mathrm{TE}-652)$ \\
\hline Air flowrate & $300 \mathrm{~g} / \mathrm{min}$ \\
\hline Reactor pressure & $500 \mathrm{psig}$ \\
\hline Reactor $\tau$ & $\sim 7-8 \mathrm{~seconds}$ at peak desorber flow \\
\hline Purge fluid & Water \\
\hline Purge flowrate & $20 \mathrm{~g} / \mathrm{min}$ \\
\hline Quench flowrate & Off \\
\hline Quenched temperature & $<500^{\circ} \mathrm{C}$ \\
\hline Effluent pH & Should be $>2.0$ based on prior runs \\
\hline Hours at Steady State & TD at $\sim 500^{\circ} \mathrm{C}$ for 1 hour \\
\hline
\end{tabular}




\section{Feed Recipe (Desorber canister charge)}

\begin{tabular}{|l|c|c|l|}
\hline Surrogate \#1: Average Composition & wt\% & g per canister & \multicolumn{1}{|c|}{ Notes } \\
\hline Iron base metal alloys & 10.09 & 77.5 & Use steel and stainless steel hardware \\
\hline Other metals/alloys & 0.25 & 1.9 & Use brass fittings \\
\hline Oil Dry (kitty litter) & 7.11 & 54.6 & Purchase \\
\hline Paper/Wood & 38.84 & 298.2 & Use scrap \\
\hline Lead lined gloves, gloves, gaskets & 0.86 & 6.6 & Use lead-lined gloves supplied by SRS \\
\hline PVC, polyethylene & 40.88 & 313.9 & Use household bags, etc. \\
\hline $\mathrm{CeO}_{2}$ & 0.02 & 0.129 & Purchase \\
\hline $\mathrm{CCl}_{4}$ & 0.98 & 7.5 & Purchase \\
\hline $\mathrm{C}_{2} \mathrm{Cl}_{4}$ & 0.98 & 7.5 & Purchase \\
\hline $\mathrm{Total}$ & 100.0 & 767.7 & \\
\hline
\end{tabular}

The canister should be lined with 34 grams of PVC to simulate the drum liner before loading the surrogate.

\section{Configuration and Setup}

1. See attached PFD.

2. Calibrate low range $\mathrm{CO}$ meter at $100 \mathrm{ppm}$. We are required to demonstrate $\mathrm{CO}<100$ ppm.

3. Clean the $1 / 2 " \times 0.065$-in. C-276 line connecting the TD and SCWO units. The orifice has been removed since run 8.1 .

4. Vessel reactor internals are removable C-276 insulated liner with titanium Grade 2, 3-in Sch. 10 pipe (3.5 in. OD x 3.28 in. ID).

5. The nozzle core tube will carry the hot (but cooling down) gases from the TD, diesel fuel and DI water (P-100). The core tube will be $1 / 4$ inch $\times 0.065$ wall Alloy C-276 tubing.

6. The nozzle annulus tube will carry pre-heated air and water. The annulus tube will be a standard Dugway nozzle, 1/2" x 0.065 wall Alloy C-276 tubing, with the orifice block drilled through to 0.277 inches to allow the core tube to end flush with the annulus.

7. The optional gas and liquid effluent filters are not installed for this run.

8. All heaters on the TD unit and the jumper heating tape are operational. 


\section{Procedure}

1. Startup

a. Pressurize reactor with water and air and heat to $\geq 270^{\circ} \mathrm{C}$ using air and water through the preheater. Activate heating tape on overhead line from TD to SCWO.

b. Start P-100 process water at minimum reliable flow.

c. Start diesel fuel at $\sim 3 \mathrm{~g} / \mathrm{min}$ and adjust as required to attain reactor temperature of $650^{\circ} \mathrm{C}$. Ramp fuel to target reactor temperature while adjusting pre-heater outlet temperature to $\sim 550^{\circ} \mathrm{C}$ to $600^{\circ} \mathrm{C}$. In view of the low operating pressure, make sure system is operating cleanly with low $\mathrm{CO}$.

2. Transition to feed and operate

a. Use the following ramp rates for the TD heaters:

1. $25^{\circ} \mathrm{C} / \mathrm{min}$ to $250^{\circ} \mathrm{C}$.

2. $3^{\circ} \mathrm{C} / \mathrm{min}$ to $370^{\circ} \mathrm{C}$.

3. $0.5^{\circ} \mathrm{C} / \mathrm{min}$ to $450^{\circ} \mathrm{C}$.

4. $1^{\circ} \mathrm{C} / \mathrm{min}$ to $480^{\circ} \mathrm{C}$.

5. $10^{\circ} \mathrm{C} / \mathrm{min}$ to $550^{\circ} \mathrm{C}$. When setpoint is reached, raise setpoint to $580^{\circ} \mathrm{C}$. When setpoint is reached, raise setpoint to $600^{\circ} \mathrm{C}$.

b. Set P-100 as necessary to maintain $650^{\circ} \mathrm{C}$ in SCWO reactor.

c. Run until TD has been at $\sim 500^{\circ} \mathrm{C}$ for 1 hour.

3. Shut down
a. Turn off TD heaters.
b. Turn off ohmic heater.
c. Turn off fuel, then air.
d. Shut down all SCWO system flows. Allow GLS to drain to depressurize SCWO system.

e. Disconnect the TD and SCWO systems.

\section{Contingencies}

1. Watch for feed line plugging. As the TD vapors cool from mixing with P-100 water, tars will condense in the feed line. 
2. Hydrochloric acid corrosion of the nozzle and downstream components, especially the steel GLS, may be a problem. Quench may be brought on if the effluent $\mathrm{pH}$ falls below 2.

\section{Sample Schedule}

\begin{tabular}{|c|c|c|c|c|}
\hline Sample \# & Description & Frequency & Quantity & Analyses \\
\hline \hline $\begin{array}{c}\text { MMDDYY HH:MM - } \\
\text { Effluent }\end{array}$ & $\begin{array}{c}\text { Liquid } \\
\text { effluent }\end{array}$ & $15 \mathrm{~min}$ & $250 \mathrm{ml}$ & TOC, cerium \\
\hline $\begin{array}{c}\text { TD-SCWO1-Sx } \\
\text { (x indicates sample } \\
\text { number) }\end{array}$ & TD residues & End of run & & Ultimate, cerium \\
\hline AirKinetics sampling & Gas Effluent & $\begin{array}{c}\text { Start when TD } \\
\text { temperature is } \\
240^{\circ} \mathrm{C}\end{array}$ & & $\begin{array}{c}\text { See AirKinetics } \\
\text { quote }\end{array}$ \\
\hline
\end{tabular}

Only selected samples will be analyzed, others will be saved for archival purposes.

\section{Post-Run Inspection}

1. Inspect TD canister and take usual weights and samples. If run was successful, send usual solid samples to Hazen.

2. Inspect nozzle and TD-SCWO connecting line.

3. Take digital photographs of significant items.

4. Complete post run inspection sheet prior to TD-SCWO restart. 
GA Pilot Plant Run Plan

* general atomics

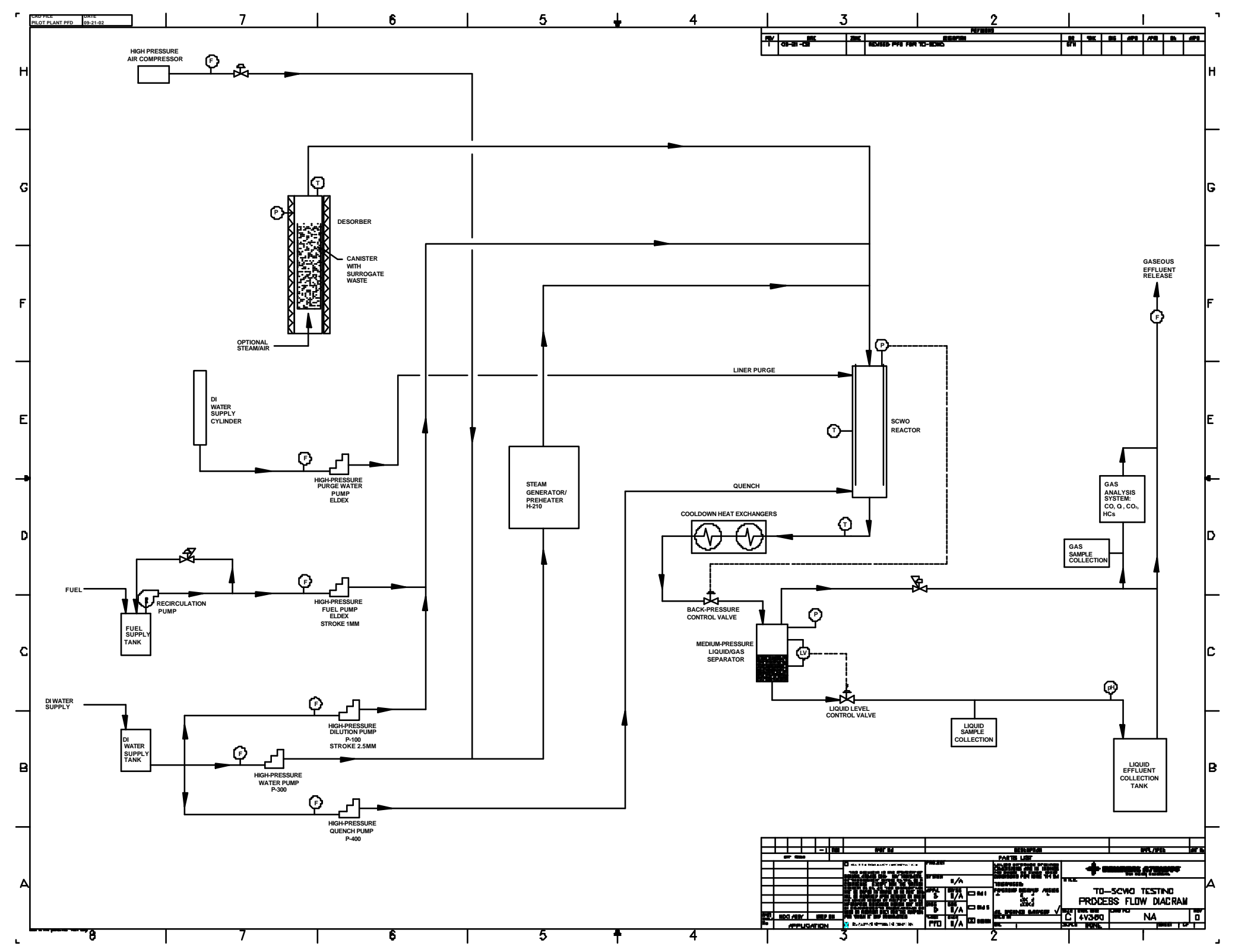


APPENDIX B. AirKinetics Report on Gas Effluent Analyses 


\title{
ENGINEERING TEST REPORT
}

\section{SCRUBBER EFFLUENT}

\author{
Source Location: \\ General Atomics \\ 3550 General Atomics Ct \\ San Diego, California 92121-1122
}

Test Date: September 19, 2002

Issue Date: October 23, 2002

Revision: 0

Prepared for:

General Atomics

18 Wachusett View Drive

Westborough, Massachusetts 01581

Prepared by:

Airkinetics, Inc.

5932 Bolsa Avenue, Suite 105

Huntington Beach, California 92649

714-373-0998

714-895-1915 (Fax)

AKI No.: 11303
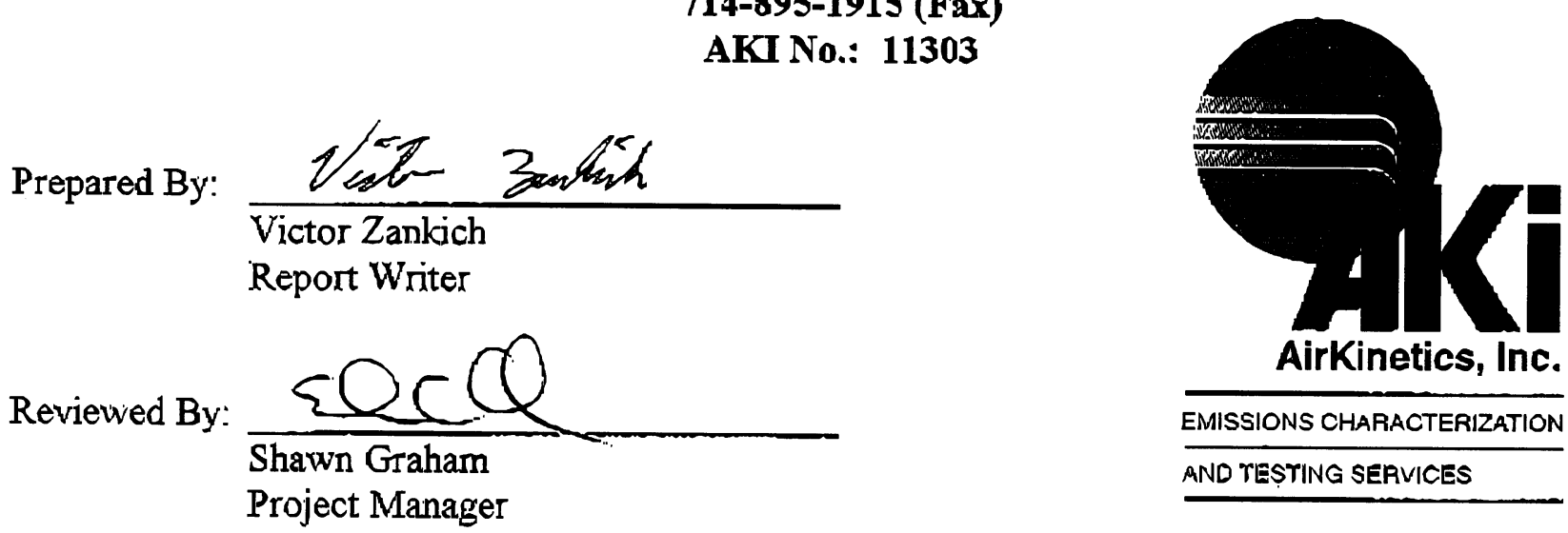
1.0 SUMMARY

1.1 Source Information

Page

1.2 Testing Firm Information

$1-1$

1.3 Test Information.

$1-1$

1.4 Test Personnel

\section{APPENDICES}

A. RESULTS TABULATION

1.0 Unit No. 1

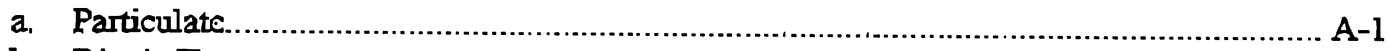

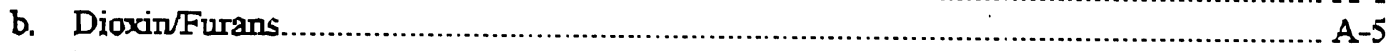

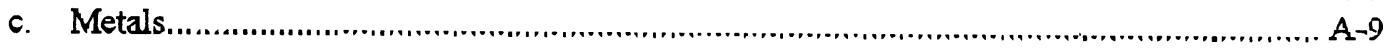

\section{B. eXample Calculations}

1.0 Particulate. B-1

2.0 Dioxin/Furans

B-3

3.0 Metals

\section{ANALYTICAL DATA}

1.0 Unit No. 1
a. Particulate. C-1
b. Dioxin/Furans ..C-4
c. Metals. C-13
d. $\mathrm{CCl}_{4}$ and $\mathrm{Cl}_{4}$ C-23 


\subsection{SUMMARY}

\subsection{Source Information}

Facility Name and Address: General Atomics 3550 General Atomics Ct

San Diego, Califomia 92121-1122

Source Tested:

Scrubber Effluent Stack

Facility Contact:

Glenn Hong, General Atomics

Phone Number:

508-870-0109

\subsection{Testing Firma Information}

Firm Name and Address:

Airkinetics, Inc.

5932 Bolsa Avenue, Suite 105

Huntington Beach, CA 92649

Firm Contact:

Shawn Graham

Phone Number:

714-373-0998. Ext. 27

Subcontractors:

Air Toxics Ltd., Fulsom, CA

Alta Analytical Laboratory Inc, E1 Dorado Hills, CA

1.3 Test Information

Test Requested By:

General Atomics

Finon Contact:

Glenn Hong

Phone Number:

508-870-0109

Test Objective:

To determine compliance with permitted emission limits

Test Methads:

EPA 5

EPA 23

EPA 29

Particulate

EPA TOlS

Dioxin/Furans

Metals

$\mathrm{CCl}_{4}$ and $\mathrm{Cl}_{4}$

Test Dates:

Seprember 19, 2002

\subsection{Test Personnel}

Test Coordinators:

Glemn Hong, General Atomics,

AirKinetics Test Personnel:

Shawn Graham, Project Manager

Jose Orellana, Sampling Team Leader 


\section{D TEST RESULTS AND DATA PRESENTATION}

The results of the testing are summarized in Tables 2-1. Results tabulations are presented in Appendix A. Example calculations are given in Appendix B. Analytical data are provided in Appendix C.

TABLE 2-1

\section{SCRUBBER EFFLUENT TEST RESULTS}

\begin{tabular}{|c|c|c|c|c|}
\hline \multirow{2}{*}{\multicolumn{3}{|c|}{ 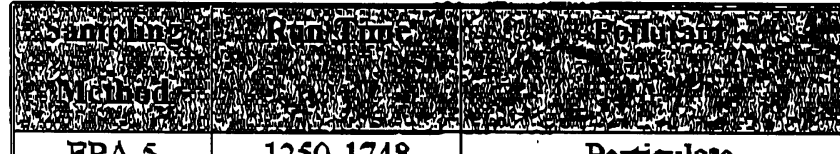 }} & $\begin{array}{l}4 \\
4\end{array}$ & (4) \\
\hline & & & $\mathrm{mg} / \mathrm{DSCM}$ & 0.105 \\
\hline \multirow[t]{3}{*}{ EPA 23} & \multirow[t]{3}{*}{$1147-1747$} & Total PCDDs & $\mathrm{ng} / \mathrm{DSCM}$ & 0.00489 \\
\hline & & Total PCDFs & $\mathrm{ng} / \mathrm{DSCM}$ & 0.0192 \\
\hline & & Total PCDDs and PCDFs & $\mathrm{ng} / \mathrm{DSCM}$ & 0.0240 \\
\hline \multirow[t]{8}{*}{ EPA 29} & \multirow[t]{8}{*}{$1250-1748$} & Antimouy & ug/DSCM & 0.0131 \\
\hline & & Arsenic & ug/DSCM & $\mathrm{ND}(<0.565)$ \\
\hline & & Beryllium & ug DSCM & $N D(<0,283)$ \\
\hline & & Cadmium & ugdDSCM & 0.0216 \\
\hline & & Chromium & $\mathrm{ug} / \mathrm{DSCM}$ & $\mathrm{ND}(<0.565)$ \\
\hline & & Cerium & ug/DSCM & $\mathrm{ND}(<1.40)$ \\
\hline & & Lead & $\mathrm{ug} / \mathrm{DSCM}$ & 0.148 \\
\hline & & Mercury & ug/DSCM & 0.158 \\
\hline \multirow[t]{2}{*}{ EPA TO15 } & \multirow[t]{2}{*}{$1250-1350$} & Carbon Tetrachloride & ppbvd & 60 \\
\hline & & $\mathrm{C}_{2} \mathrm{Cl}_{4}$ Tetrachloride & ppbvd & 68 \\
\hline
\end{tabular}

ND - Not Detected 
Engineering Test Report

Page: $\hat{\jmath}-1$

General Atomics

Revision: 0

San Diego, California

Date: October 23, 2002

\subsection{INTRODUCTION}

On September 19, 2002 AirKinetics, Inc. conducted source emissions testing for General Atomics at General - Atomics in San Diego, California. The testing was conducted on Scrubber Effluent. The objective of the test program was to determine compliance with permined emission limits. The methods used during this test program were EPA Method 5 for particulate. EPA Method 23 for dioxin/furans, EPA Method 29 for Metals and EPA Method TO15 for $\mathrm{CCl}_{4}$ and $\mathrm{Cl}_{4}$.

All sampling was conducted at a single point and constant rate. The sampling equipment for particulate, metals and dioxin/furans was leak checked before and after each test run with no leaks found. The evacuated canister used to determine $\mathrm{CCl}_{4}$ and $\mathrm{Cl}_{4}$ concentration presented in this report has been corrected for the determined leak. 


\section{APPENDIX A}

\section{RESULTS TABULATION}

\section{a. PARTICULATE}




\section{ISOKINETIC SAMPLING TRAIN RESULTS - METHOD: M5}

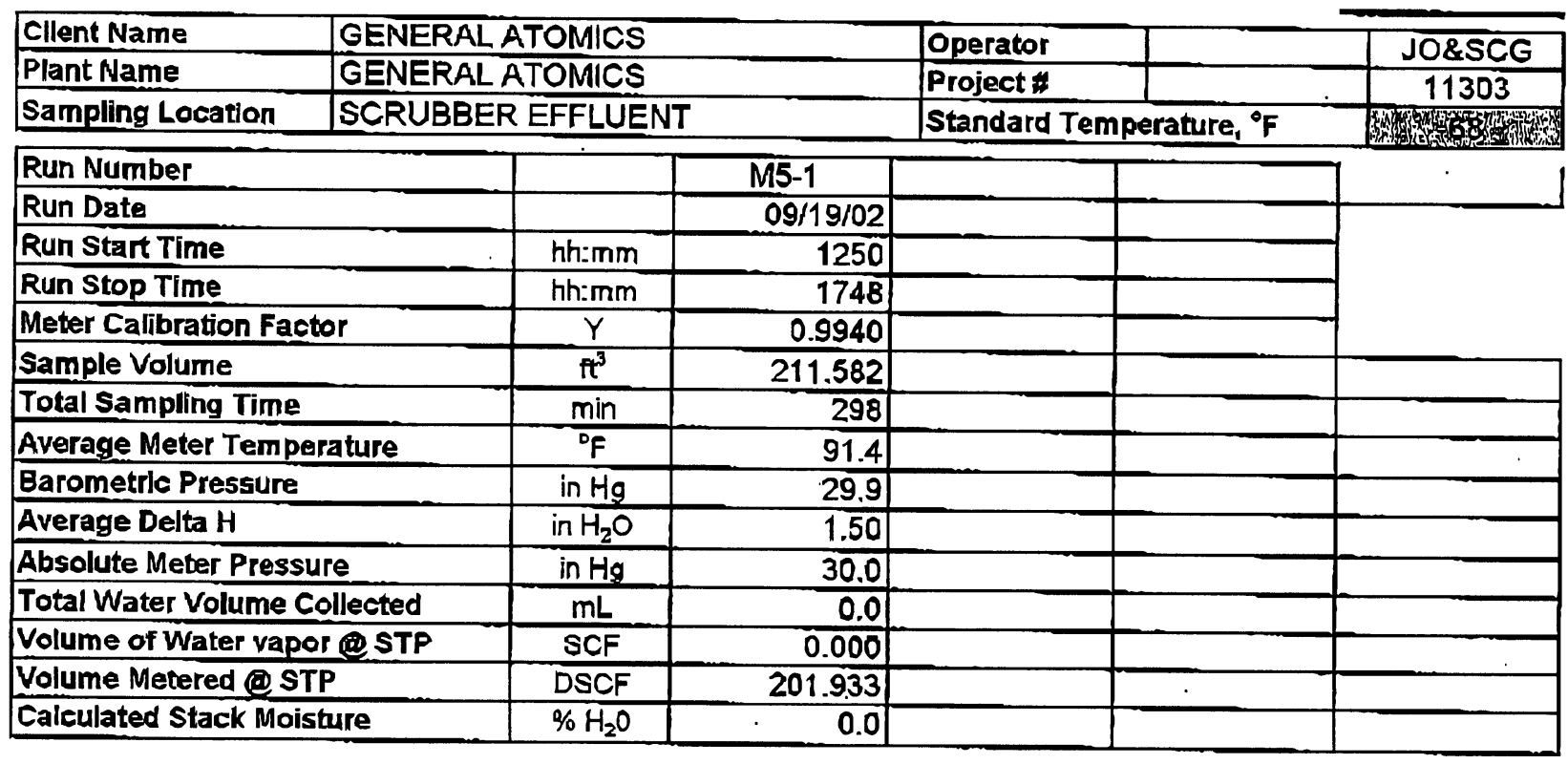




\section{ISOKINETIC SAMPLING TRAIN RESULTS - METHOD: M5}

\begin{tabular}{|c|c|c|}
\hline \begin{tabular}{|l|} 
Total Particulate \\
\end{tabular} & $\mathrm{mg}$ & 0.6 \\
\hline Concentration, grams/DSCF & $\mathrm{gms} / \mathrm{DSCF}$ & 2.97E-06 \\
\hline Concentration, Gr/DSCF & $\mathrm{gr} / \mathrm{DSCF}$ & $4.59 E-05$ \\
\hline Concentration mg/DSCM & $\mathrm{mg} / \mathrm{DSCM}$ & 1.05E-01 \\
\hline
\end{tabular}


Plant Name General Atomics

City/State

San Diego, CA
Run Number

Sampling Dare

Analysis Date

Analyst
Job No. 11303

Sampling Location Scrubber Effluent

Reagent DI H2O

Final Weight, $g$

Tared Weight, g

Water Catch, $\mathbf{g}$

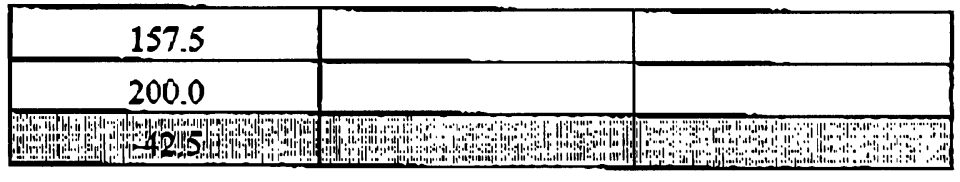

Reagent

Final Weight, $g$

Tared Weight, $g$

Water Catch, $\mathrm{g}$

\begin{tabular}{|c|l|l|}
\hline MS-1 & & \\
\hline $9 / 19 / 02$ & & \\
\hline 9/20/02 & & \\
\hline SG & & \\
\hline
\end{tabular}

Reagent $\quad 4 \% \mathrm{KMnO}_{4} / 10 \% \mathrm{H}_{2} \mathrm{SO}_{4}$

Final Weight, g ml used, $g^{*}$

Empty Tared Weight, $\mathrm{g}$ Water Catch, $g$
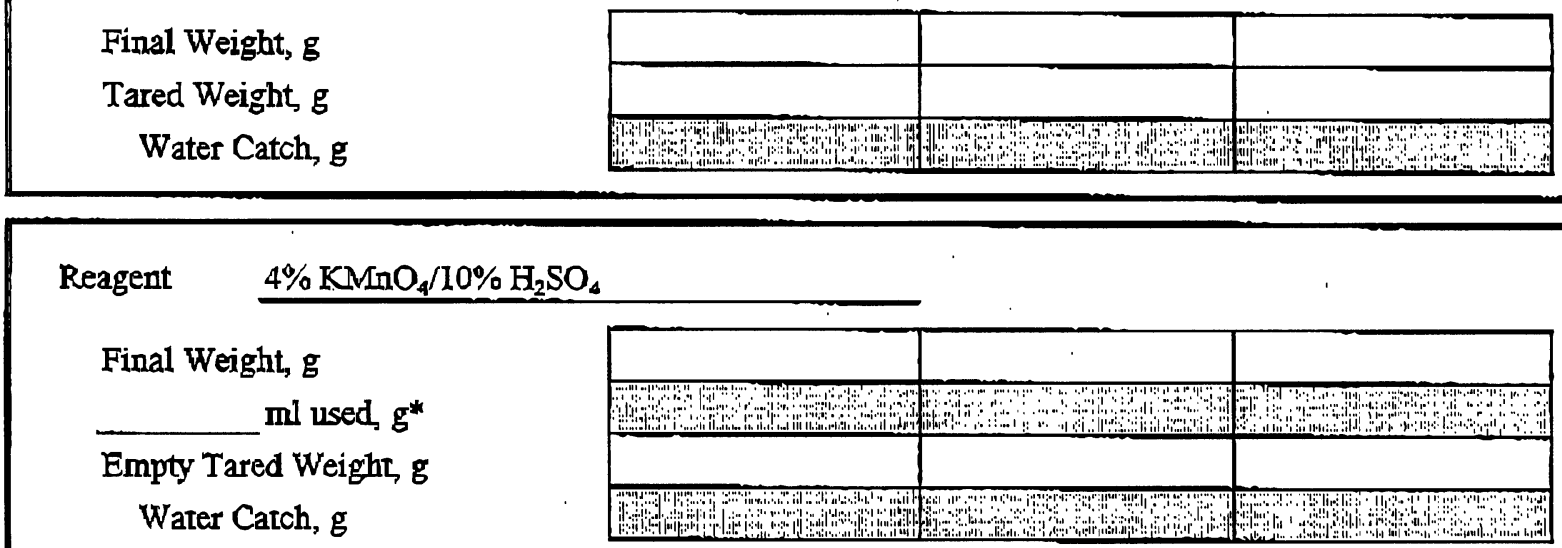

*Weight of Reagent calculated by multiplying ml of $\mathrm{KMnO}_{4}$ by density of $1.1 \mathrm{~g} / \mathrm{ml}$

CONDENSED WATER, $g$

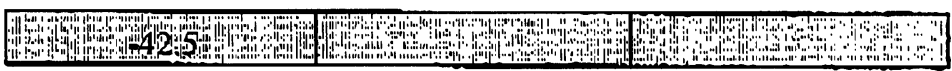

Silica Gel

Final Weight, g

Tared Weight, g

ADSORBED WATER, $g$

\begin{tabular}{|c|c|c|}
\hline 233.8 & & \\
\hline 200.0 & & \\
\hline mingy & & \\
\hline
\end{tabular}

TOTAL WATER COLLECTED, g

Puty

Balance No. Lab-1

Balance located in stable, draft-free area?

$\begin{array}{ll}\square \text { Triple Beam } & \square \text { Electronic } \\ \text { 四es } & \square \text { No }\end{array}$

Comments

Reviewer

AirKinetics, Inc. 
APPENDIX A

\section{RESULTS XABULATION}

b. DIOXIN/FURANS 


\section{ISOKINETIC SAMPLING TRAIN RESULTS - METHOD: EPA 23}

\begin{tabular}{|c|c|c|c|c|c|c|}
\hline Client Name & GENEF & OMICS & & Operator & & JO\&SGG \\
\hline Plant Name & GENEF & OMICS & & Project \# & & 11303 \\
\hline Sampling Locatlon & SCRUE & EFFLUE & & Standard & & 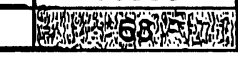 \\
\hline Run Number & & & M23-1 & & & \\
\hline Run Date & & & $09 / 19 / 02$ & & & \\
\hline Run Start Time & & hh:mm & 1147 & & & \\
\hline Run Stop Time & & hh:mm & 1747 & & & \\
\hline Meter Calibration Fa & & $Y$ & 1.0013 & & & \\
\hline Sample Volume & & $\mathrm{ft}^{3}$ & 259.652 & & & \\
\hline Total Sampiling Tlme & & $\min$ & 360 & & & \\
\hline Average Meter Temp & ature & ${ }^{\circ} \mathrm{F}$ & 80.5 & & & \\
\hline Barometric Pressure & & in $\mathrm{Hg}$ & 29.9 & & & \\
\hline Average Delta H & & in $\mathrm{H}_{2} \mathrm{O}$ & 1.10 & & & \\
\hline Absolute Meter Pres & & in $\mathrm{Hg}$ & 30.0 & & & \\
\hline Total Water Volume & ollected & $\mathrm{mL}$ & 0.0 & & & \\
\hline Volume of Water vap & r@STP & SCF & 0.000 & & & \\
\hline Volume Metered $\mathbf{0}$ & & DSCF & 254.402 & & & \\
\hline Calculated Stack Mo & bure & $\% \mathrm{H}_{2} \mathrm{O}$ & 0.0 & & & \\
\hline
\end{tabular}


Plant Name:

Sampling Location:

Run Number:

Run Date:

Parameter

PCDDs$$
\text { 2,3,7,8-TCDD }
$$$$
\text { Other TCDD }
$$$$
\text { Total TCDD }
$$$$
\text { 1,2,3,7,8-PeCDD }
$$$$
\text { Other PeCDD }
$$$$
\text { Total PeCDD }
$$

$1,2,3,4,7,8-H x C D D$

$1,2,3,6,7,8-H \times C D D$

$1,2,3,7,8,9-\mathrm{H} \times C D D$ Other HXCDD

Total HXCDD

1,2,3,4,6,7,8-HPCDD Other HPCDD

Total-HPCDD OCDD

TOTAL PCDDS

PCDFs

$\begin{array}{rcr}2,3,7,8-T C D F & 0 & 0.00 E+00 \\ \text { Other TCDF } & 138 & 1.92 E-02 \\ 1,2,3,7,8-P e C D F & 0 & 0.00 E+00 \\ 2,3,4,7,8-P e C D F & 0 & 0.00 E+00 \\ \text { Other PeCDF } & 0 & 0.00 E+00 \\ 1,2,3,4,7,8-H \times C D F & 0 & 0.00 E+00 \\ 1,2,3,6,7,8-H \times C D F & 0 & 0.00 E+00 \\ 2,3,4,6,7,8-H \times C D F & 0 & 0,00 E+00 \\ 1,2,3,7,8,9-H \times C D F & 0 & 0.00 E+00 \\ \text { Other HXCDF } & 0 & 0.00 E+00 \\ 1,2,3,4,6,7,8-H P C D F & 0 & 0.00 E+00 \\ 1,2,3,4,7,8,9-H P C D F & 0 & 0.00 E+00 \\ \text { Other HPCDF } & 0 & 0.00 E+00 \\ \text { OCDF } & 0 & 0.00 E+00 \\ & & \\ \text { TOTAL PCDFs } & 138 & 1.92 E-02 \\ \text { TOTAL PCDDs and PCDFs } & 173 & 2.40 E-02\end{array}$

GENERAL ATOMICS

SCRUBBER EFFLUENT

M23-1

09/19/02

Catch Weight $\overline{\text { Concentrations }}$

(pg) (ng/DSCM)

$0.00 E+00$
$4.89 E-03$
$0.00 E+00$
$0.00 E+00$
$0.00 E+00$
$0.00 E+00$
$0.00 E+00$
$0.00 E+00$
$0.00 E+00$
$0.00 E+00$
$0.00 E+00$
$0.00 E+00$
$0.00 E+00$
$0.00 E+00$
$0.00 E+00$
$4.89 E-03$

35.2

0

0

0

0

0

0

0

0

0

0

0

0

35

4

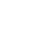


MOISTURE ANALYTICAL RESULTS - METHOD

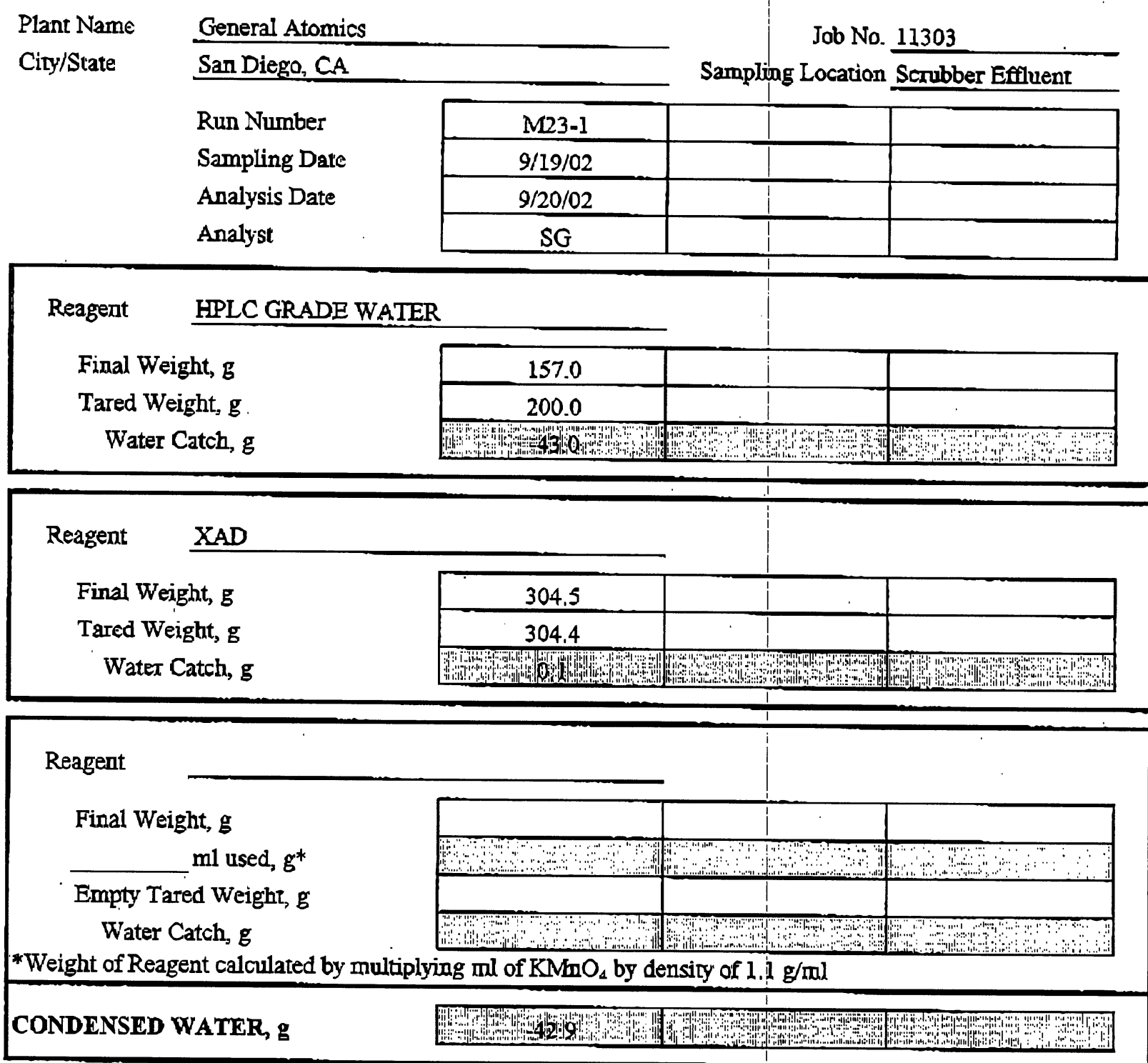

\section{Silica Gel}

Final Weight, $\mathbf{g}$

Tared Weight, $g$

ADSORBED WATER, $g$

\begin{tabular}{|c|c|c|c|}
\hline 242.3 & & & \\
\hline 200.0 & & & \\
\hline$m^{2}$ & & & \\
\hline
\end{tabular}

TOTAL WATER COLLECTED, $g$

[1]

Balance No. Lab-1

Balance located in stable, draft-free area?

$\square$ Triple Beam $\quad \square$ Eectronic

VYes

Comments 
APPENDDX A

\section{RESULTS TABULATION}

c. METALS 


\section{ISOKINETIC SAMPLING TRAIN RESULTS - METHOD: EPA 29}

\begin{tabular}{|c|c|c|c|c|c|}
\hline \multirow{3}{*}{\begin{tabular}{|l|} 
Client Name \\
Plant Name \\
Sampling Location \\
\end{tabular}} & \multicolumn{3}{|c|}{ GENERAL ATOMICS } & Operator & \multirow{2}{*}{\begin{tabular}{|c|} 
SCG \\
11303 \\
\end{tabular}} \\
\hline & \multicolumn{3}{|c|}{ GENERAL ATOMICS } & Project \# & \\
\hline & \multicolumn{3}{|c|}{ SCRUBBER EFFLUENT } & Standard Temperature, ${ }^{\circ} \mathrm{F}$ & 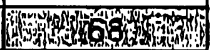 \\
\hline \multicolumn{3}{|l|}{ Run Number } & M29-1 & & \\
\hline \multicolumn{2}{|l|}{ Run Date } & & $09 / 19 / 02$ & & \\
\hline \multicolumn{2}{|l|}{ Run Start TIme } & hh:mm & 1250 & & \\
\hline \multicolumn{2}{|l|}{ Run Stop Time } & hh:mm & 1748 & & \\
\hline \multicolumn{2}{|c|}{ Meter Callbration Factor } & $\bar{Y}$ & 1.0328 & & \\
\hline \multicolumn{2}{|l|}{ Sample Volume } & $\pi^{3}$ & 199.752 & & \\
\hline \multicolumn{2}{|c|}{ Total Sampling Time } & $\min$ & 298 & & \\
\hline \multicolumn{2}{|c|}{ Average Meter Temperature } & ${ }^{\circ} \mathrm{F}$ & 81.1 & & \\
\hline \multicolumn{2}{|l|}{ Barometrle Pressure } & in $\mathrm{Hg}$ & 29.9 & & \\
\hline \multicolumn{2}{|l|}{ Average Delta H } & in $\mathrm{H}_{2} \mathrm{O}$ & 1.50 & & \\
\hline \multicolumn{2}{|c|}{ Absolute Meter Pressure } & in $\mathrm{Hg}$ & 30.0 & & \\
\hline \multirow{2}{*}{\multicolumn{2}{|c|}{$\begin{array}{l}\text { Total Water Volume Collected } \\
\text { Volume of Water vapor @ STP }\end{array}$}} & $\mathrm{mL}$ & 0.0 & & \\
\hline & & SCF & 0.000 & & \\
\hline \multicolumn{2}{|c|}{ Volume Metered (2) STP } & DSCF & 201.855 & & \\
\hline \multicolumn{2}{|c|}{ Calculated Stack Moisture } & $\% \mathrm{H}_{2} \mathrm{O}$ & 0.0 & & \\
\hline
\end{tabular}




\section{ISOKINETIC SAMPLING TRAIN RESULTS - METHOD: EPA 29}

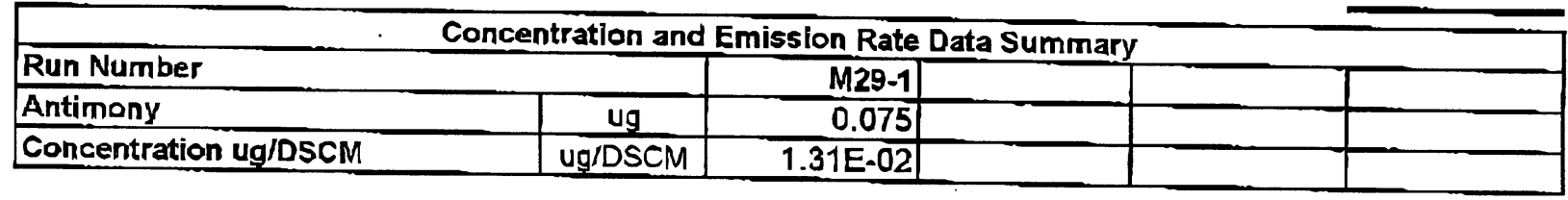

\begin{tabular}{|l|c|c|c|c|c|}
\hline Arsenic & $\mathrm{ug}$ & $<3.230$ & & & \\
\hline Concentration ug/DSCM & ug/DSCM & $<5.65 \mathrm{E}-01$ & & & \\
\hline
\end{tabular}

\begin{tabular}{|l|c|l|l|l|l|}
\hline Beryllium & ug & $<1.615$ & & & \\
\hline Concentration ug/DSCM & ug/DSCM & $<2.83 \mathrm{E}-01$ & & & \\
\hline
\end{tabular}

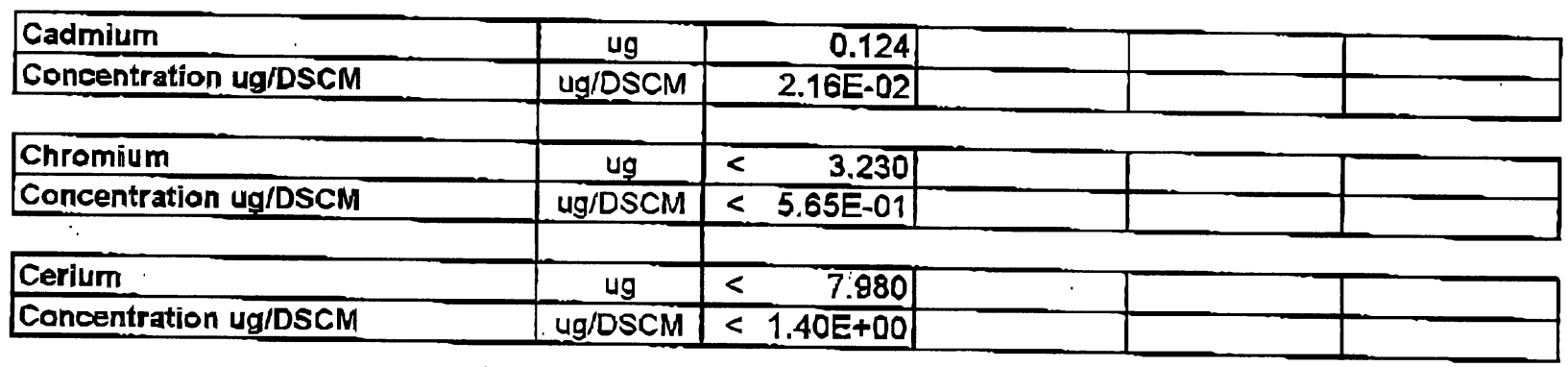

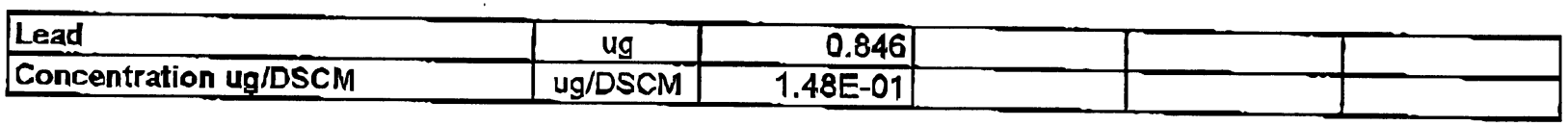

\begin{tabular}{|l|c|c|c|c|c|}
\hline Mercury & ug & $<0.904$ & & & \\
\hline Concentration ug/DSCM & ug/DSCM & $<1.58 \mathrm{E}-01$ & & & \\
\hline
\end{tabular}


Plant Name:

Sampling Location:

Run Number:

Run Date:

Parameter

PCDDs
GENERAL ATOMICS SCRUBBER EFFLUENT M23-1

09/19/02

Catch Weight Concentrations

(pg) (ng/DSCM)

$\begin{array}{cc}4.48 & 6.22 \mathrm{E}-04 \\ 30.72 & 4.26 \mathrm{E}-03 \\ 3.44 & 4.77 \mathrm{E}-04 \\ 0 & 0.00 \mathrm{E}+00 \\ 5.45 & 7.56 \mathrm{E}-04 \\ 5.17 & 7.18 \mathrm{E}-04 \\ 5.21 & 7.23 \mathrm{E}-04 \\ -10.55 & -1.46 \mathrm{E}-03 \\ 5.81 & 8.06 \mathrm{E}-04 \\ 0 & 0.00 \mathrm{E}+00 \\ 12.8 & 1.78 \mathrm{E}-03 \\ 63 & \\ & 8.68 \mathrm{E}-03\end{array}$

PCDFs

TOTAL PCDDS

$\begin{array}{rcc}2,3,7,8-T C D F & 3.35 & 4.65 \mathrm{E}-04 \\ \text { Other TCDF } & 134.65 & 1.87 \mathrm{E}-02 \\ 1,2,3,7,8-\mathrm{PeCDF} & 3.56 & 4.94 \mathrm{E}-04 \\ 2,3,4,7,8-\mathrm{PeCDF} & 3.32 & 4.61 \mathrm{E}-04 \\ \text { Other PeCDF } & -3.44 & -4.77 \mathrm{E}-04 \\ 1,2,3,4,7,8-\mathrm{H} \text { XCDF } & 2.57 & 3.57 \mathrm{E}-04 \\ 1,2,3,6,7,8-\mathrm{H} \text { XCDF } & 2.47 & 3.43 \mathrm{E}-04 \\ 2,3,4,6,7,8-\mathrm{H} \text { XCDF } & 2.89 & 4.01 \mathrm{E}-04 \\ 1,2,3,7,8,9-\mathrm{H} \text { XCDF } & 3.31 & 4.59 \mathrm{E}-04 \\ \text { Other HXCDF } & -8.47 & -1.18 \mathrm{E}-03 \\ 1,2,3,4,6,7,8-\mathrm{HpCDF} & 2.61 & 3.62 \mathrm{E}-04 \\ 1,2,3,4,7,8,9-\mathrm{HPCDF} & 3.22 & 4.47 \mathrm{E}-04 \\ \text { Other HPCDF } & -2.95 & -4.09 \mathrm{E}-04 \\ \text { OCDF } & 9.28 & 1.29 \mathrm{E}-03 \\ \text { TOTAL PCDFs } & 156 & 2.17 \mathrm{E}-02 \\ \text { TOTAL PCDDs and PCDFs } & 219 & 3.04 \mathrm{E}-02\end{array}$




\section{MOISTURE ANALYTICAL RESULTS - METHOD}

\begin{tabular}{|c|c|c|c|}
\hline Plant Name & \multicolumn{2}{|l|}{ General Atomics } & \multirow{2}{*}{$\begin{array}{l}\text { Job No. } 11303 \\
\text { Sampling Location Scrubber Effluen }\end{array}$} \\
\hline City/State & \multicolumn{2}{|l|}{ San Diego, CA } & \\
\hline & \multirow{4}{*}{$\begin{array}{l}\text { Run Number } \\
\text { Sampling Date } \\
\text { Analysis Date } \\
\text { Analyst }\end{array}$} & M29-1 & \\
\hline & & $9 / 19 / 02$ & \\
\hline & & $9 / 20 / 02$ & \\
\hline & & SG & \\
\hline
\end{tabular}

Reagent $5 \% \mathrm{HNO} 3 / 10 \% \mathrm{H} 2 \mathrm{O} 2$

Final Weight, $\mathbf{g}$

Tared Weight, $\mathrm{g}$

Water Catch, $\mathrm{g}$

\begin{tabular}{|c|c|c|}
\hline 240.0 & & \\
\hline 271.8 & & \\
\hline 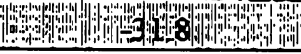 & Ming & 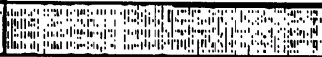 \\
\hline
\end{tabular}

Reagent EMPTY MMPLNGER

Final Weight, $g$

Tared Weight, $g$

Water Catch, $\mathbf{g}$

\begin{tabular}{|c|c|c|}
\hline 30.9 & & \\
\hline 30.9 & & \\
\hline & & \\
\hline
\end{tabular}

Reagent $\quad 4 \% \mathrm{KMnO}_{4} / 10 \% \mathrm{H}_{2} \mathrm{SO}_{4}$

Final Weight, $g$

$200 \quad \mathrm{ml}$ used, $\mathrm{g}^{*}$

Empty Tared Weight, g

Water Catch, $g$ [6.

Weight of Reagent calculated by multiplying $\mathrm{ml}$ of $\mathrm{KMnO}_{4}$ by density of $1.1 \mathrm{~g} / \mathrm{ml}$

CONDENSED WATER, $g$

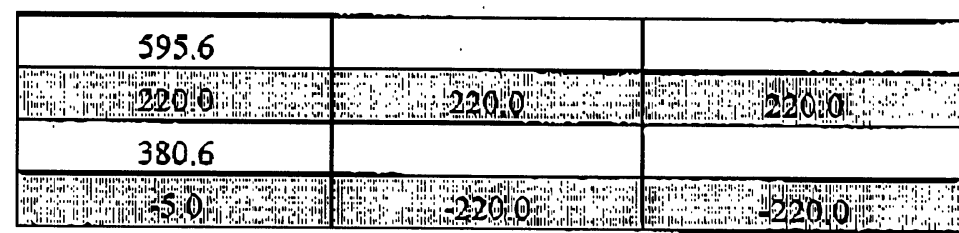

Silica Gel

Final Weight, $\mathbf{g}$

Tared Weight, $\mathrm{g}$

ADSORBED WATER, g

\begin{tabular}{|l|l|l|}
\hline 231.6 & & \\
\hline 200.0 & & \\
\hline$\left.y_{1}+4\right)$ & & \\
\hline
\end{tabular}

TOTAL WATER COLLECTED, g

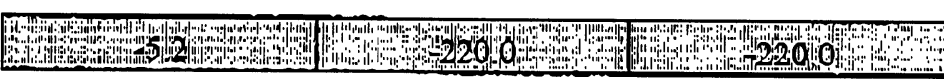

Balance No. Lab-1

Balance located in stable, draft-free area?

$\begin{array}{ll}\square \text { Triple Bearn } & \text { ■Electronic } \\ \text { ■Yes } & \square \text { No }\end{array}$

Comments

Reviewer

AirKinetics, Inc. 


\section{APPENDIX $B$}

\section{EXAMPLE CALCULATIONS}

\subsection{PARTICULATE}




\section{EXAMPLE CALCULATIONS, RUN M5-1}

ABSOLUTE PRESSURE, INCHES OF MERCURY

$$
\begin{aligned}
\mathrm{PS} & =\mathrm{Pbar}+\mathrm{Pg} / 13.6 \\
& =29.90+0.00 / 13.6 \\
& =29.90
\end{aligned}
$$

VOLUME OF WATER VAPOR STANDARD CUBIC FEET

Vwstd $=0,002667 *[($ Tstd +460$) /$ Pstd $]$ *Vlc

$=0.002667 *[(68+460) / 28.92 * 0.0$

$=0.000$

SAMPLED VOLUME OF SOURCE GAS, DRY STANDARD CUBIC FEET

Vmstd $=[(T s t d+460) / P s t d]=Y=V m$ * $(P b a r+$ Delta-H/13.6) $/(460+\mathrm{tm})$

$=[(68+460) / 29.92] * 0.9940 * 211.582 *(29.90+1.500 / 13.6) /(460+91)$

$=201.933$

MOISTURE CONTENT, PERCENT BY VOLUME

$\% \mathrm{H} 2 \mathrm{O}=$ Vwstd $/(\mathrm{Vwstd}+\mathrm{Vmstd})$

$=0.000 /(0.000+201.933)$

$=0.00$

FILTERABLE PARTICULATE CONCENTRATION, GRAINS PER DRY STANDARD CUBIC FOOT

gr/DSCF $=($ Catch/Conversion $) * 7,000 / 453.592 /$ Vmstd

$=(0.60 / 1000) * 7,000 / 453.592 / 201.933$

$=0.00005$ 


\section{APPENDIX B}

EXAMPLE CALCULATIONS

\subsection{DIOXIN/FURANS}




\section{EXAMPLE CALCULATIONS, RUN M23-1}

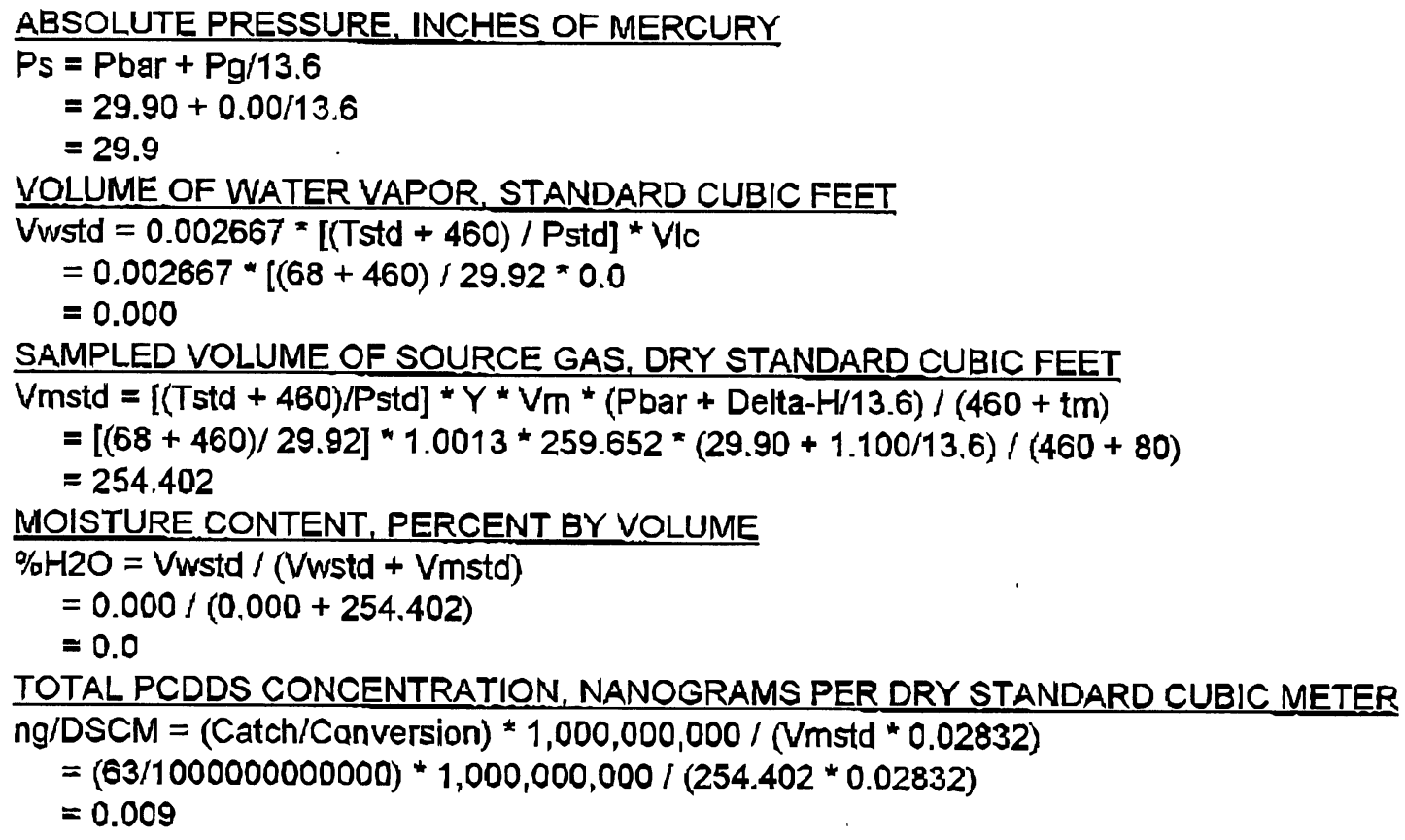

SAMPLED VOLUME OF SOURCE GAS, DRY STANDARD CUBIC FEET

Vmstd $=[(T s t d+460) / P s t d] * Y * V m *(P b a r+$ Delta-H/13.6) $/(460+\mathrm{tm})$

$=[(68+460) / 29.92] * 1.0013 * 259.652 *(29.90+1.100 / 13.6) /(460+80)$

$=254.402$

MOISTURE CONTENT, PERCENT BY VOLUME

$\% \mathrm{H} 2 \mathrm{O}=\mathrm{Vwwstd}_{\text {w }} /(\mathrm{Vwstd}+\mathrm{Vmstd})$

$=0.000 /(0.000+254.402)$

$=0.0$

TOTAL PCDDS CONCENTRATION, NANOGRAMS PER DRY STANDARD CUBIC METER

$\mathrm{ng} / \mathrm{DSCM}=($ Catch/Canversion) $* 1,000,000,000 /$ (Vmstd *0.02832)

$=(63 / 1000000000000) * 1,000,000,000 /(254.402 * 0.02832)$

$=0.009$ 


\section{APPENDIX B}

\section{EXAMPLE CALCULATIONS}

\subsection{METALS}




\section{EXAMPLE CALCULATIONS, RUN M29-1}

VOLUME OF WATER VAPOR, STANDARD CUBIC FEET

Vwstd $=0.002667=[(T s t d+460) /$ Pstd $] *$ Vlc

$=0.002667 *[(68+460) / 29.92 * 0.0$

$=0.000$

SAMPLED VOLUME OF SOURCE GAS, DRY STANDARD CUBIC FEET

Vmstd $=\cdot[($ Tstd +460$) /$ Pstd $]=Y * V m *($ Pbar + Delta-H/13.6) $/(460+\mathrm{tm})$

$=[(68+460) / 29.92] * 1.0328 * 199.752 *(29.90+1.500 / 13.6) /(460+81)$

$=201.855$

MOISTURE CONTENT, PERCENT BY VOLUME

$\% \mathrm{H} 2 \mathrm{O}=\mathrm{Vwstd} /(\mathrm{Vwstd}+\mathrm{Vmstd})$

$=0.000 /(0.000+201.855)$

$=0.00$

CADMIUM CONCENTRATION, MICROGRAMS PER DRY STANDARD CUBIC METER

ug/DSCM $=($ Catch/Conversion $) * 1,000,000 /$ (Vmstd*0.02832)

$=(0.12 / 1,000,000) * 1,000,000 /\left(201.855^{*} 0.02832\right)$

$=0.022$ 
APPENDIX C

ANALYTICAL DATA

a. PARTICULATE 


\section{PARTICULATE SAMPLING LABORATORY RESULTS (Version 11.16.99)}

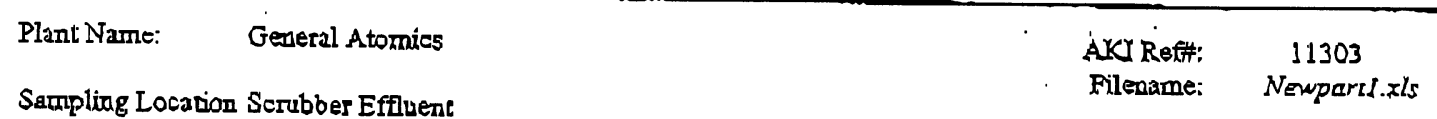

Date Received: Siptember 20,2002

File Pathway: H:UOBSIIIJOBSI300JOBSI1 1303WNEWPART1.XIS

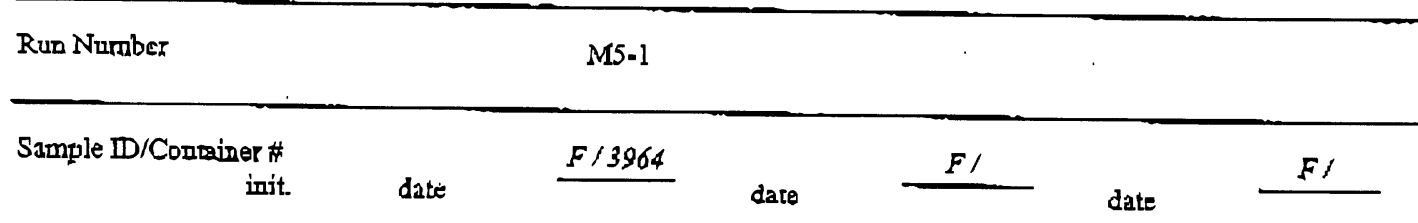

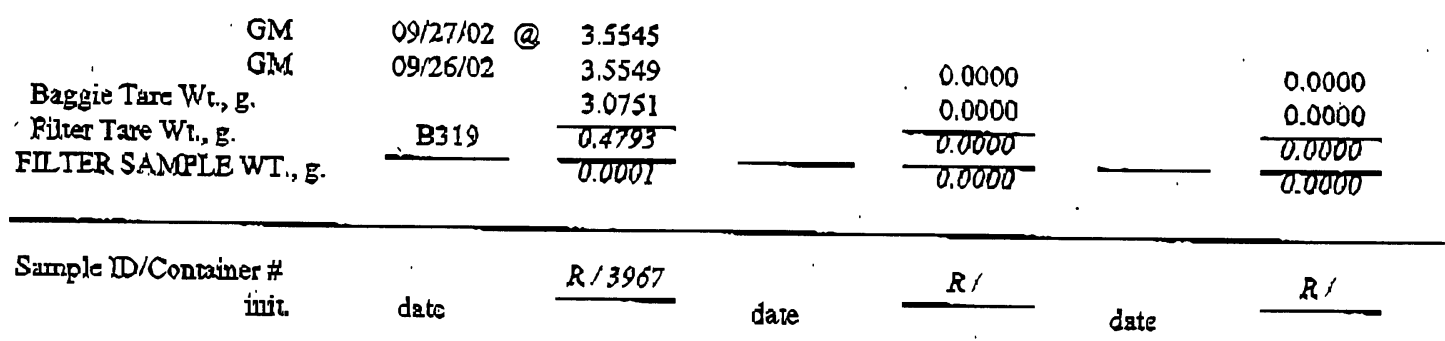

\begin{tabular}{|c|c|c|c|c|c|c|}
\hline $\begin{array}{l}\text { GMI } \\
\text { GMI }\end{array}$ & 09/27/02@ & 3.5333 & & & & \\
\hline $\begin{array}{l}\text { Tare Wh., g. } \\
\text { RNSSE SAMLLE WT., g. }\end{array}$ & $\left(\begin{array}{r}09 / 26 / 02 @ \\
75 \mathrm{mil})\end{array}\right.$ & $\begin{array}{l}3.5333 \\
3.5327 \\
0.0006\end{array}$ & ml) & $\begin{array}{l}0.0000 \\
0.0000 \\
0.0000\end{array}$ & mil) & $\begin{array}{l}0.0000 \\
0.0000\end{array}$ \\
\hline
\end{tabular}

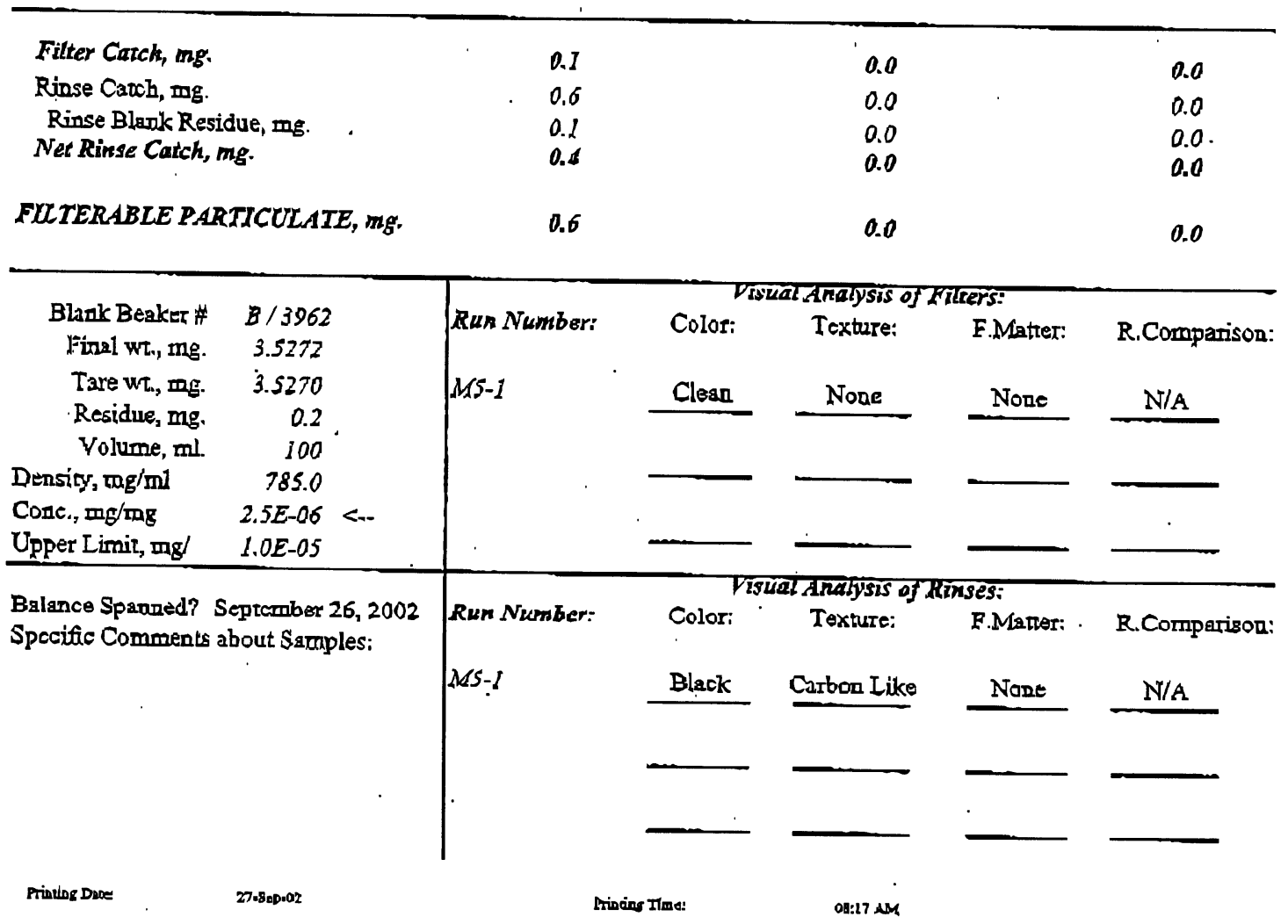


REAGENT BLANK LABORATORY RESULTS (Version 11.16.99)

\section{Plant Name: General Atomics}

....- Sampling Location N/A

Date Received: Seprember 20,2002

File Pathway:

H: JJOBS $\backslash 11 \mathrm{JOBS} \backslash 300$ JOBS $\backslash 11303$ NEWPART1.XIS
AKI Ref\#: $\quad 11303$

Filename: Newpart1.xls

Run Number

Acetone

Sample ID/Container \# init.

date

$B / 3962$

\begin{tabular}{|c|c|c|}
\hline \multirow{2}{*}{$\begin{array}{l}\text { GM } \\
\text { GM }\end{array}$} & $09 / 27 / 02$ & 3.5273 \\
\hline & 09/26/02@ & 3.5272 \\
\hline & $100 \mathrm{ml})$ & $\begin{array}{l}3.5270 \\
0.0002\end{array}$ \\
\hline
\end{tabular}

Date of full balance span

September 26, 2002

Notes and comments: 
APPENDIX C

ANALYTICAL DATA

b. DIOXIN/FURANS 


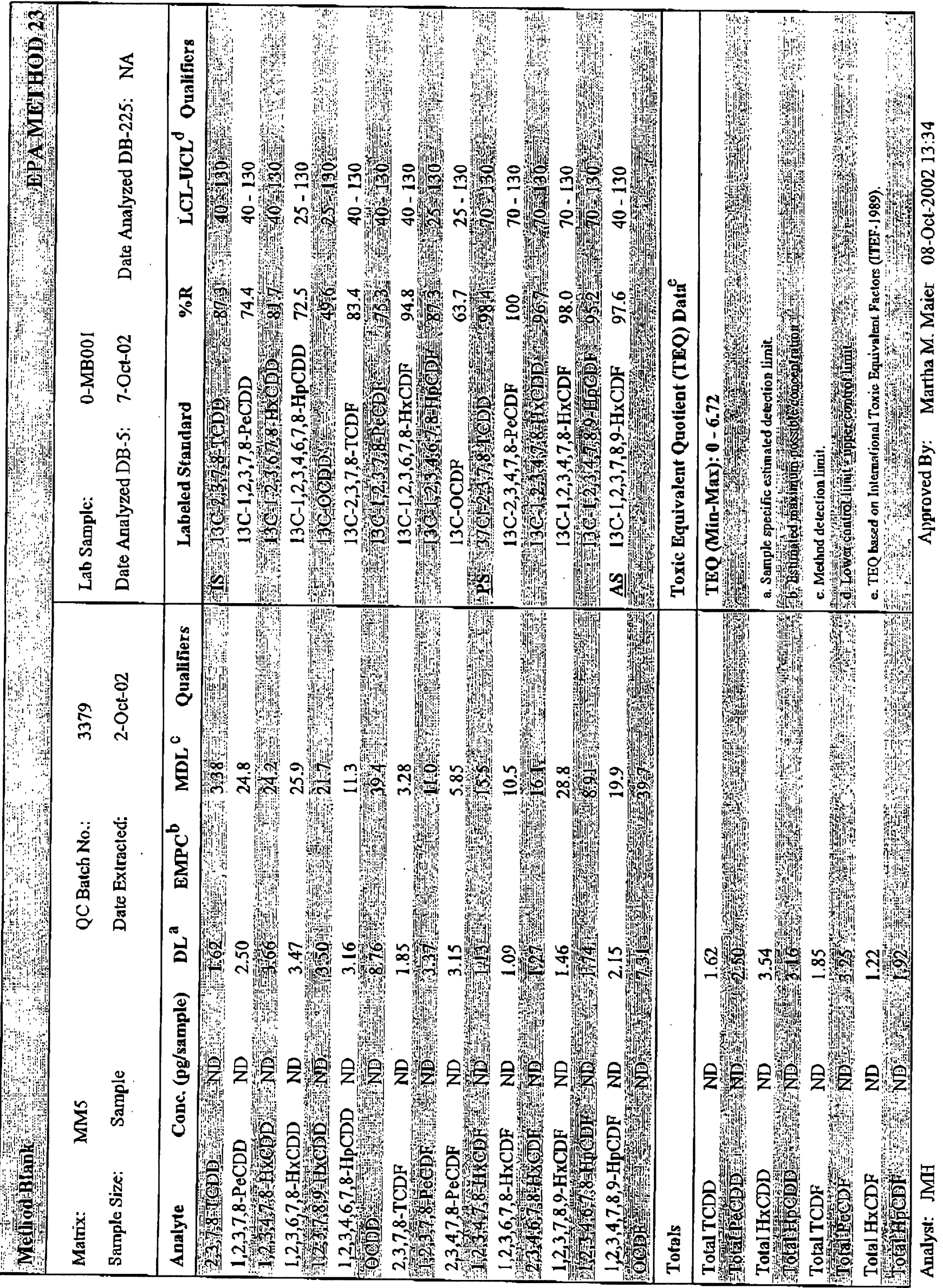

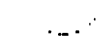




\section{(1)}

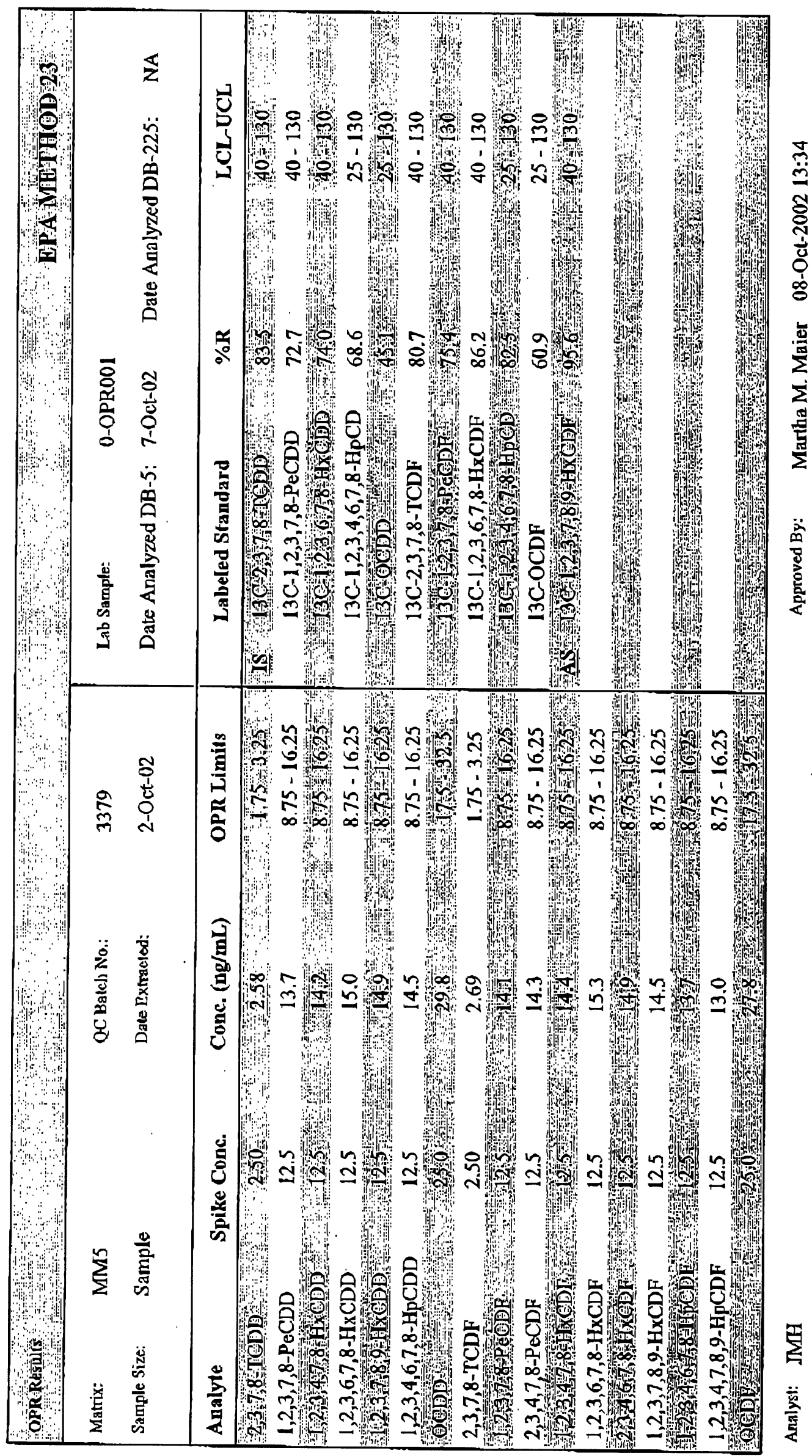




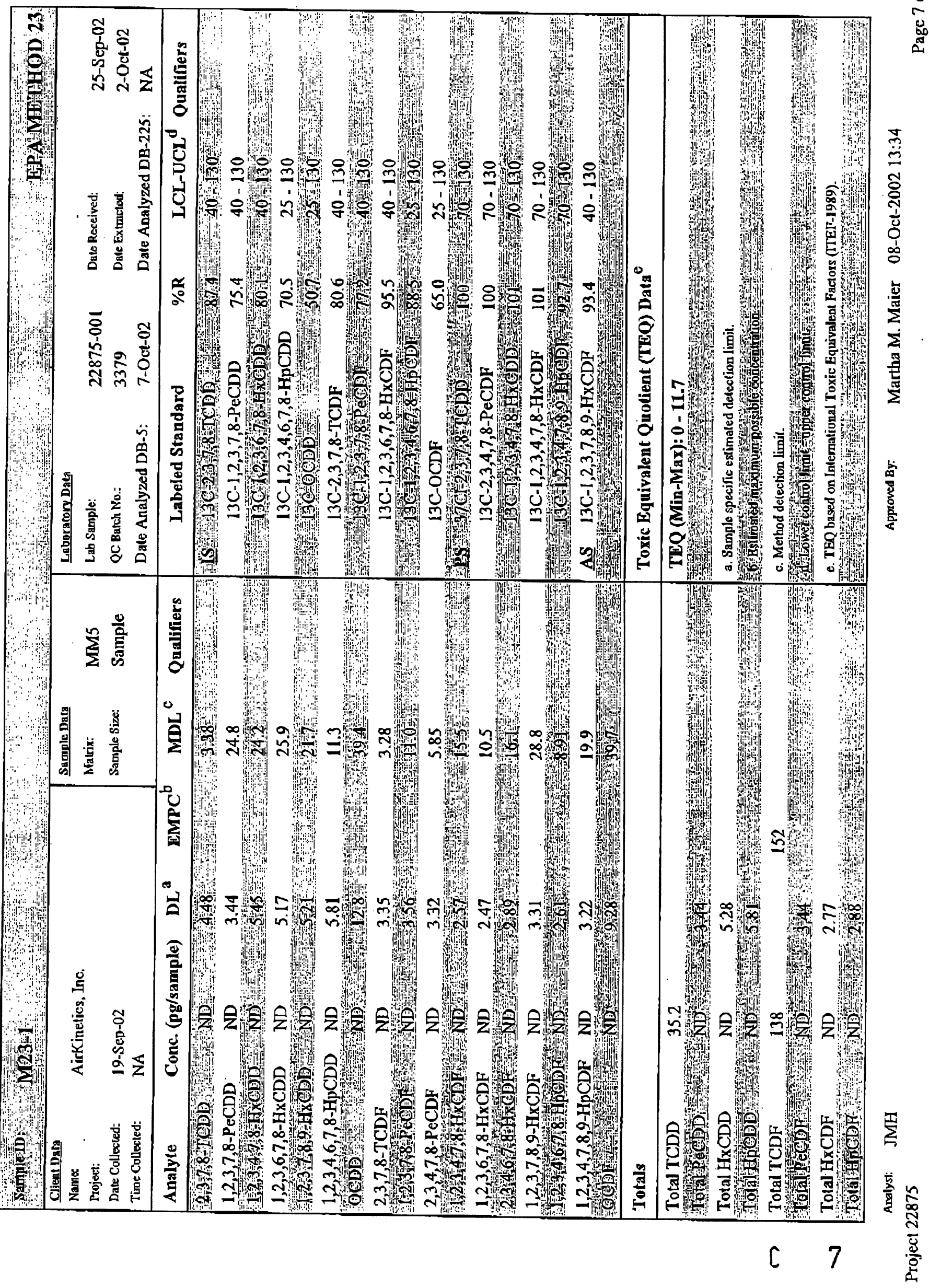




\section{APPENDLX}




\section{DATA QUALIFIERS \& ABBREYIATIONS}

A

B

D

$\mathbf{E}$

H

I

*

Conc.

DL

EMPC

NA

ND

TEQ
The amount detected is below the Lower Calibration Limit of the instrument. This compound was also detected in the method blank.

The amount reported is the maximum possible concentration due to possible chlorinated diphenylether interference.

The amount detected is above the Upper Calibration Limit of the instrument.

The signal-to-noise ratio is greater than 10:1.

Chemical Interference

See Cover Letter

Concentration

Sample-specific estimated detection limit

Estimated Maximum Possible Concentration

Not applicable

Not Detected

Toxic Equivilancy 


\section{CURRENT CERTIFICATIONS}

NELAP - (Primary AA: Califomia, Certificate No. 02102CA)

Department of the Navy

U.S. Army Corps of Engineers

\section{U.S, EPA Region 5}

Commonwealth of Kentucky - (Certificate No. 90063)

Bureau of Reclamation - Mid-Pacific Region - (MP-470, Res-1.10)

Commonwealth of Kentucky - (Certificate No. 90063)

Commonwealth of Virginia - (Certificate No. 00013)

State of Alaska, Department of Environmental Conservation - (Certificate No. OS-00197)

State of Arkansas, Department of Health - (Approval granted through CA certification)

State of Arkansas, Department of Environmental Quality

State of California - (Certificate No. 1640)

State of Connecticut - (Certificate No. PH-0182)

State of Florida - (Certificate No. 87456)

State of Louisiana, Department of Health and Hospitals - (Certificate No. LA000014)

State of Louisiana, Department of Environmental Quality

State of Mississippi - (Approval granted through CA certification)

State of Nevada - (Certificate No. CA413)

State of New Jersey - (Certificate No. CA003)

State of New York, Department of Health - (Certificate No. 11411)

State of North Carolina - (Certification No. 06700)

State of North Dakota, Department of Health - (Certificate No. R-078)

State of Oregon - (Certificate No. CA413)

State of Pennsylvania - (Certificate No. 68-490)

State of South Carolina - (Certificate No. 87002001)

State of Tennessee - (Certificate No. 02996)

State of Texas - (Certificate No. TX247-1000A

State of Utah - (Certificate No, E-201)

State of Washington - (Certification No. C091)

State of Wisconsin - (Certificate No. 998036160)

State of Wyoming - (USEPA Region 8 Ref: 8TMS-Q) 


\section{AirKinetics, Inc.}

EMISSIONS CHARACTERIZATION AND TESTING SERVICES

REQUEST FOR ANALYSIS

PURCHASE ORDER NO.:

$\frac{1844-G M}{\text { Alta Analytical }}$

JOB NAME: General Atomics

LABORATORY:

Alta Analytical

JOB No: 11303

DATE SAMPLES

WERE TRANSMITTED:

$$
9-25-02
$$

\section{EXPECTED DATE}

OF RESULTS:

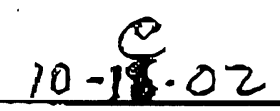

SAMPLEMATRX:

Acetone, Methylene Chloride and Toluerse

TYPE OF ANALYSIS REQUIRED: Please analyze according to EPA Method 23 for Dioxin/Furans.

A full raw data package will be required.
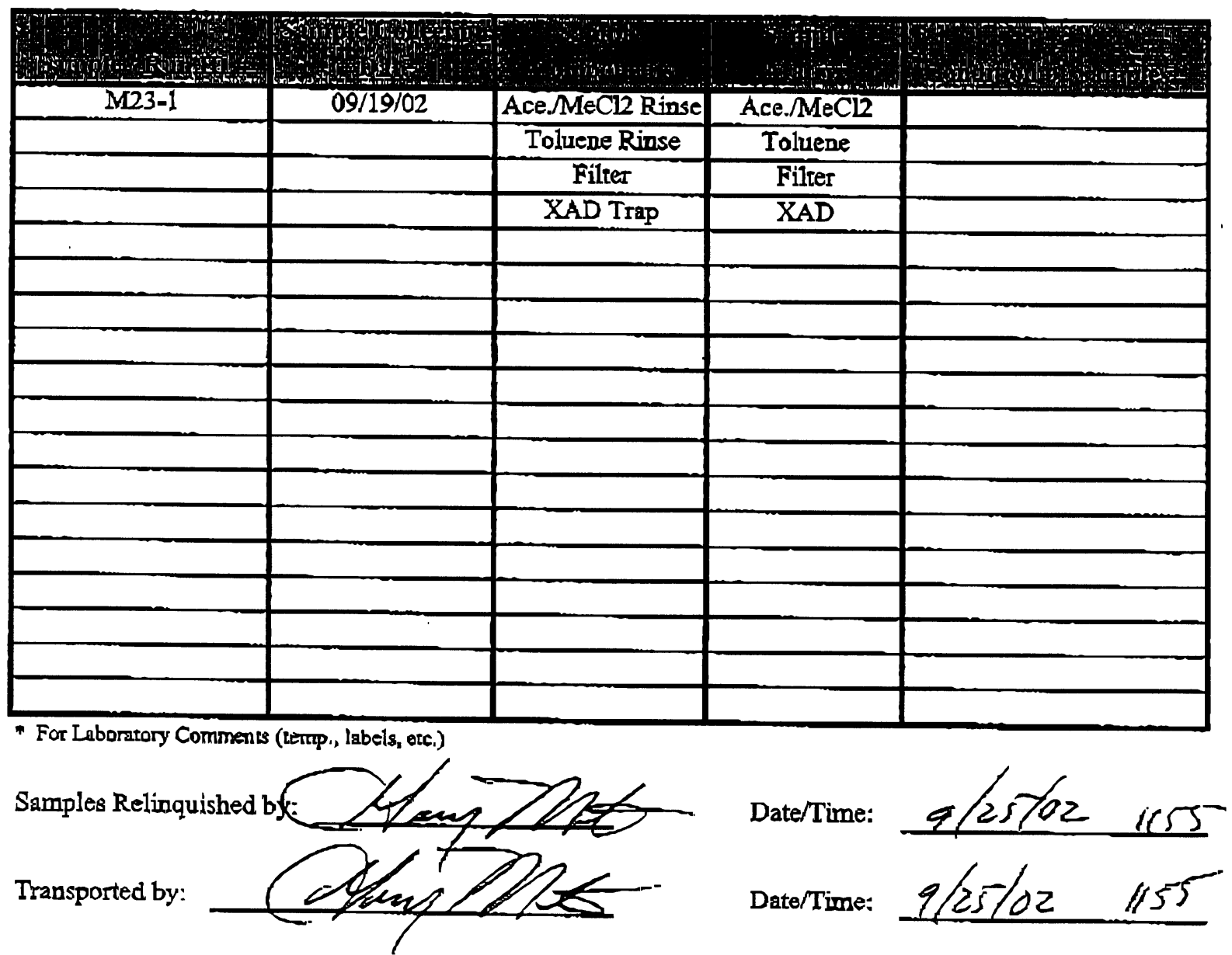

Transported to:

Alta Analytical

5070 Robert J. Mathews Parkway

Eldorado Hills, CA 95762

Received by:

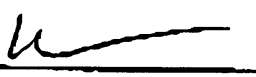

Date/Time: 


\section{SAMPLE LOG-IN CHECKLIST}

\section{ALTA Project No.: 22875}

\begin{tabular}{|c|c|c|c|}
\hline 1. Date Samples Arrived: $\quad 09 / 25 / 02$ & \multicolumn{3}{|c|}{ Location: } \\
\hline 2. Time / Dare logged in:. & \multicolumn{3}{|c|}{ Location: WR-2 } \\
\hline 3. Samples Arrived By: (circle) FedEx UPS World Courier Other: HAND CARRY & & & \\
\hline 4. Shipping Presenvation: (circle) Ice Blue ice / Dry lce / None Temp ${ }^{\circ} \mathrm{C}$ & $0.8^{\circ} \mathrm{C}$ & & \\
\hline \multirow[b]{2}{*}{ 5. Shipping Container(s) Intact"? If not, describe condition in comment section. } & YES & NO & NA \\
\hline & $x$ & & \\
\hline \multirow{2}{*}{$\begin{array}{l}\text { 6. Shipping Container(s) Custody Seals Present? } \\
\text { Intact? If not intact, describe condition in comment section. }\end{array}$} & & $x$ & \\
\hline & & & $x$ \\
\hline $\begin{array}{l}\text { 7. Shipping Documentation Present? (circle) Shipping Label Airbill } \\
\text { Tracking Number: }\end{array}$ & & $x$ & \\
\hline \multirow{2}{*}{$\begin{array}{l}\text { 8. Sample Cusfody Seal(s) Present? No. of Seals___ or Seal No. } \\
\text { Intact? If not intact, describe condition in comment section. }\end{array}$} & & $x$ & \\
\hline & & & $x$ \\
\hline 9. Sample Container Intact? If no, indicate sample condition in comment section. & $x$ & & \\
\hline 10. Chaln of Custody (COC) or other Sample Documentation Present? & $x$ & & \\
\hline 11. COc/Documentation Acceptable? If no, complete COC Anomaly Form. & $\underline{x}$ & & \\
\hline \multicolumn{4}{|l|}{ 12. Shipping Container (circle): ALTA Elient Retain or Return or Disposed } \\
\hline 13. Container(s) and/or Bottle(s) Requested? & & $x$ & \\
\hline $\begin{array}{l}\text { 14. Drinking Water Sample? (HRMS Only) If yes, Acceptable Preservation? } Y \text { or } N \\
\text { Preservation Info From? (circle) COC or Sample Container or None Noted }\end{array}$ & & & $x$ \\
\hline
\end{tabular}

\section{Comments:}




\section{APPENDIX C}

\section{ANALYTICAL DATA}

\section{c. METALS}


ATRCOETICS, INC.

Client Sanqle ID: N29-1

IOTAI Metals

Lot-Sample \#. . : : G2I250284-001

Date Sampled...: 09/19/02

PARAMETER RASULT

REPORTING IIMIT

UNITS METHOD

Prep Batch \#. . . : 2270246

Hig (KMnO4)

Fg (FH) ND

Hg (fDrO3/H202)

$0.012 \mathrm{~B}$

0.10

0.030

$\operatorname{ug}$

0.51

ug

0.19

ig

ND $G$

$\mathrm{Hg}$ (Empty)

ID $G$

2270294

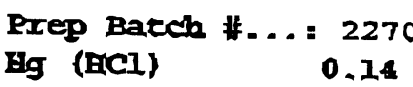

0.10

$\operatorname{ug}$

EW846 7470A

SW846 74TOA

SW846 7470A

SW846 7470A

SW846 7470A

ug

Prep Batch \#...: 2273457

Arsenic

Berylizirm

Cadinim

Cerium

chromium

Eead

Antimony
ND

ND

$0.23 \mathrm{~B}$

ND

ND

$0.89 \mathrm{~B}$

0.079 В
3.4

1. 7

1.7

8.4

3.4

1.7

3.4 ug

ug

ug

19

$\operatorname{ug}$

ug

ug
SW846 6020

SW846 6020

STr846 6020

5พ846 6020

SW846 6020

ST846 6020

SW846 6020
$09 / 27 / 02$

B8vTHax

Matrix. ......: AIR

PREPARATION- WORK ANALYSIS DATE ORDER \#.

$09 / 26-09 / 27 / 02$ E8VTHLAA 09/26-09/27/02 E8VTHLAL. $09 / 26-09 / 27 / 02$ E8VTF1AM 09/26-09/27/02 B8VTHLAN

09/26-10/14/02 EBVIFIAD 09/26-10/14/02 EEVTHIAE 09/26-10/14/02 EBVTHIAF 09/26-10/14/02 E8VTFIAG 09/26-10/14/02 E8VTH1AH $09 / 26-10 / 14 / 02$ B8VIHIAT 09/26-10/I4/02 B8VIHIAK

\section{$\operatorname{MOTB}(5)$}

B Exrimaoed result. Resulc is less than RL.

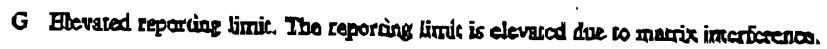


ATRRTIRITCS, MIC.

Client Sample ID: M29-RB

TOIAL Metals

Iot-Sample \#. . . G2I250284-002

Date Sampled...; 09/19/02
Date Received. .: 09/25/02
Matrix. ..... $=\mathrm{AIR}$

PREPARATION- WORK ANAEYSIS DATE ORDER \#

09/26-09/27/02 E8VTULAA 09/26-09/27/02 E8WTVIAL 09/26-09/27/02 E8VTVIAM $09 / 26-09 / 27 / 02$ EOVIVIAN

Prep Bacch \#...: 2270294

Hg (HCl) $0.079 \mathrm{~B}$

0.10

ug

ST846 74702

$09 / 27 / 02$

Baviviac

Prep Batch \#... = 2273457

$\begin{array}{lllll}\text { Arsenic } & \text { ND } & 3.8 & \text { ug } & \text { SW846 6020 } \\ \text { Berylitium } & \text { ND } & 1.9 & \text { ug } & \text { SW846 6020 } \\ \text { Cadmium } & \text { O.I4 B } & 1.9 & \text { ug } & \text { SW846 6020 } \\ \text { Cerium } & \text { ND } & 9.4 & \text { ug } & \text { SW846 6020 } \\ \text { Chromium } & \text { ND } & 3.8 & \text { ug } & \text { SW846 6020 } \\ \text { Lead } & 0.34 \text { B } & 1.9 & \text { ug } & \text { SW846 6020 } \\ \text { Antimony } & \text { 0.094 B } & 3.8 & \text { ug } & \text { SW846 6020 }\end{array}$

09/26-10/14/02 EBVTV1AD 09/26-10/14/02 BBVTVIAE 09/26-10/14/02 B8VIVIAP 09/26-10/14/02 E8VTV1AG 09/26-10/14/02 E8VIVIAH 09/26-10/14/02 BBVIVIAJ 09/26-10/14/02 EBVIVIAT

NOTF (S) :

B Escimaned resulc Result is less onar RL.

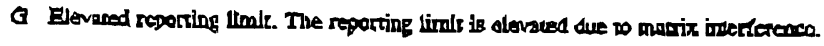




\title{
QC DATA ASSOCIATION SUMMARY
}

C2I250284

\author{
Sample Preparation and Analyais Control Numbers
}

\begin{tabular}{|c|c|c|c|c|c|}
\hline SAMPLE\# & MATRIX & $\begin{array}{l}\text { ANALYTICAL } \\
\text { METHOD }\end{array}$ & $\begin{array}{l}\text { IEACH } \\
\text { BATCH \# }\end{array}$ & $\begin{array}{l}\text { PREP } \\
\text { BATCH \# }\end{array}$ & MS RUNA\# \\
\hline \multirow[t]{3}{*}{001} & AIR & SW846 6020 & & 2273457 & 2273246 \\
\hline & AIR & BW246 T470A & & 2270246 & 2270106 \\
\hline & AIR & SWQA6 747OA & & 2270294 & \\
\hline \multirow[t]{3}{*}{002} & AIR & SW846 6020 & & 2273457 & 2273246 \\
\hline & AIR & SWB46 $7470 \mathrm{~A}$ & & 2270246 & 2270106 \\
\hline & ATR & SWR4 $67470 A$ & & 2270294 & \\
\hline
\end{tabular}




\section{NESIRTOD BLANT RRPORT}

TOLAU Metals

Client Lot \#...: G2I250284

Matrix. . ....... AIR

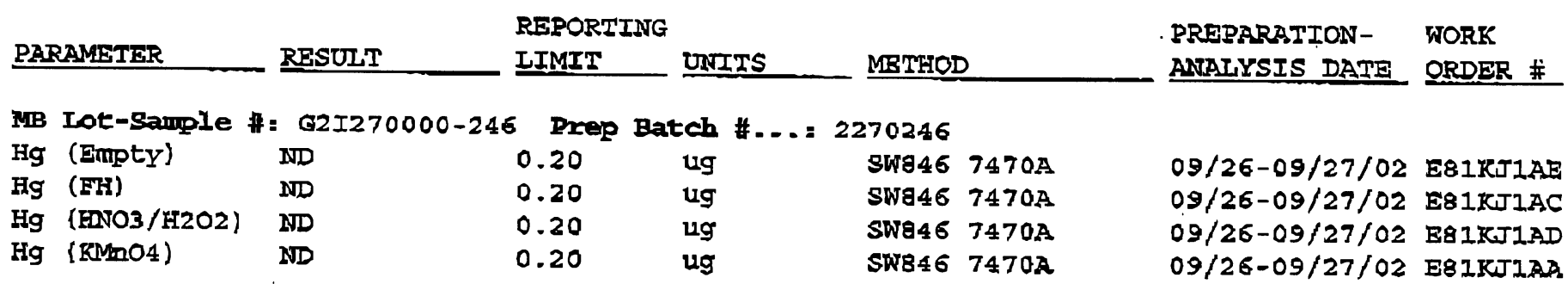

MB Iot-Sample \#: G2I270000-294 Prep Batch \#...: 2270294

Hg (HC1)

NDP 0.20

ug

SพB46 7470A

$09 / 27 / 02$

BSIVILAA

yB Iot-Sample \#: G2I300000-457 Prep Batch \#... = 2273457

Antimony

Arsenic

Beryllium

Cadmium

Cerium

Chromium

Lead

$\begin{array}{lll}\text { NDD } & 0.66 & \text { ug } \\ \text { ND } & 0.66 & \text { ug } \\ \text { ND } & 0.33 & \text { ug } \\ \text { ND } & 0.33 & \text { ug } \\ \text { ND } & 1.7 & \text { ug } \\ \text { ND } & 0.66 & \text { ug } \\ \text { ND } & 0.33 & \text { ug }\end{array}$

$5 W 8466020$

SWB46 6020

SW846 6020

SW846 6020

SW846 6020

SW846 6020

SW846 6020
$09 / 26-10 / 14 / 02$ EBSE41AH $09 / 26-10 / 14 / 02$ E85E41AR $0.9 / 26-10 / 14 / 02$ EB5E41AC 09/26-10/24/02 B85E4IAD $09 / 26-I 0 / 14 / 02$ EBSB4IAE 09/26-10/14/02 E85E4IAF $09 / 26-10 / 14 / 02$ EBSB41AG

NOTE $(S):$

Calculsidons are performed before rounding to avoid nound-off errives in ealculated reatts, 


\section{LABORATORY CONTRON SAMLILE EVALUATION REFORT}

noThu Metals

\begin{tabular}{|c|c|c|c|c|c|c|c|c|c|}
\hline \multicolumn{8}{|c|}{ Lot-Sample \#. . . : G2I250284 } & \multicolumn{2}{|c|}{ Matrix......... AIR } \\
\hline PARAMISTER & $\begin{array}{l}\text { PBRCENTT } \\
\text { RECOVERY }\end{array}$ & \multicolumn{2}{|c|}{$\begin{array}{l}\text { RECOVERY } \\
\text { LIMITS } \\
\end{array}$} & \multicolumn{2}{|r|}{$R P D$} & METHOD & & $\begin{array}{l}\text { PREPARATION- } \\
\text { AMALYSIS DATE }\end{array}$ & $\begin{array}{l}\text { PREP- } \\
\text { BATCF \# }\end{array}$ \\
\hline \multirow[t]{2}{*}{ Hg (Empty) } & 103 & 180 & -1201 & & & SW846 & $7470 \mathrm{~A}$ & $09 / 26-09 / 27 / 02$ & $\frac{\text { DATCH f }}{2270246}$ \\
\hline & 98 & (BD & -1201 & 5.0 & $(0-20)$ & SW846 & $7470 A$ & $09 / 25-09 / 27 / 02$ & 2270246 \\
\hline \multirow[t]{2}{*}{ Hg (FH) } & 103 & 〈BO & $-120\}$ & & & 5 SW 46 & $7470 \mathrm{~A}$ & $09 / 26-09 / 27 / 02$ & 2270246 \\
\hline & 98 & 180 & $-120)$ & 5.0 & $\{0-20\}$ & Sพ846 & $7470 A$ & $09 / 26-09 / 27 / 02$ & 2270246 \\
\hline \multirow[t]{2}{*}{ 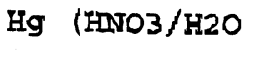 } & 103 & 180 & $-120)$ & & & SW846 & $7470 A$ & $09 / 26-09 / 27 / 02$ & 2270246 \\
\hline & 98 & 180 & $-120)$ & 5.0 & $(0-20)$ & SWB 46 & $7470 . \mathrm{A}$ & $09 / 26-09 / 27 / 02$ & 2270246 \\
\hline \multirow[t]{2}{*}{ Hg (KOnO4) } & 103 & 180 & $-120)$ & & & Sพ846 & $7470 \mathrm{~A}$ & $09 / 26-09 / 27 / 02$ & 2270246 \\
\hline & 98 & 180 & $-120)$ & 5.0 & $(0-20)$ & SW846 & $7470 \mathrm{~A}$ & $09 / 26-0.9 / 27 / 02$ & 2270246 \\
\hline \multirow[t]{2}{*}{$\mathrm{Hg} \mathrm{( \textrm {HCl } )}$} & 208 & 180 & -1201 & & & SW846 & $7470 \mathrm{~A}$ & $09 / 27 / 02$ & 2270294 \\
\hline & 107 & 180 & $-120)$ & 0.93 & $(0-20)$ & SW846 & $7470 \mathrm{~A}$ & $09 / 27 / 02$ & 2270294 \\
\hline \multirow[t]{2}{*}{ Aneimony } & 99 & 675 & $-125\}$ & & & sW846 & 6020 & $09 / 26-10 / 14 / 02$ & 2273457 \\
\hline & 96 & 175 & $-125)$ & 3.0 & $(0-20)$ & $3 W 846$ & 6020 & $09 / 26-10 / 14 / 02$ & 2273457 \\
\hline \multirow[t]{2}{*}{ Arsenic } & 96 & $\{75$ & - 125) & & & SW846 & 6020 & $09 / 26-10 / 14 / 02$ & 2273457 \\
\hline & 94 & $(75$ & $-125)$ & 1.7 & $(0-20)$ & Sw846 & 6020 & $D 9 / 26-10 / 14 / 02$ & 2273457 \\
\hline \multirow[t]{2}{*}{ Berylizium } & 91 & $(75$ & $-125)$ & & & $5 w 846$ & 6020 & $09 / 26-10 / 14 / 02$ & 2273457 \\
\hline & 87 & $(75$ & $-125)$ & 4.5 & $(0-20)$ & SW8 46 & 6020 & $09 / 26-10 / 14 / 02$ & 2273457 \\
\hline \multirow[t]{2}{*}{ Cadmín } & 99 & 175 & $-125)$ & & & sor846 & 6020 & $09 / 26-10 / 14 / 02$ & 2273457 \\
\hline & 97 & $\{75$ & $-125)$ & 2.4 & $(0-20)$ & SW846 & 6020 & $09 / 26-10 / 14 / 02$ & 2273457 \\
\hline \multirow[t]{2}{*}{ Cerium } & 103 & $\{75$ & $-125)$ & & & Sh8 46 & 6020 & $09 / 26-10 / 14 / 02$ & 2273457 \\
\hline & 105 & 675 & - 125) & 2.1 & $(0-20)$ & SW946 & 6020 & $09 / 25-10 / 14 / 02$ & 2273457 \\
\hline \multirow[t]{2}{*}{ Chromium } & 99 & 175 & $-125)$ & & & SW846 & 6020 & $09 / 25-10 / 14 / 02$ & 2273457 \\
\hline & 97 & $(75$ & - 125) & 1.7 & $(0-20)$ & SW846 & 6020 & $09 / 26-10 / 14 / 02$ & 2273457 \\
\hline \multirow[t]{2}{*}{ Iead } & 101 & $(75$ & - 125) & & & SWB46 & 6020 & $09 / 26-10 / 14 / 02$ & 2273457 \\
\hline & 98 & $(75$ & $-125\}$ & 3.2 & $(0-20)$ & SW846 & 6020 & $09 / 26-10 / 14 / 02$ & 2273457 \\
\hline
\end{tabular}

NOTB (S):

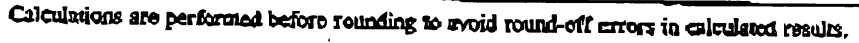


IABORATOEY CONTROI SAMPTE DATH BRPORT

TOTar Metals

Lot-sample \#... : G2I250284

Merdx.......: AIR

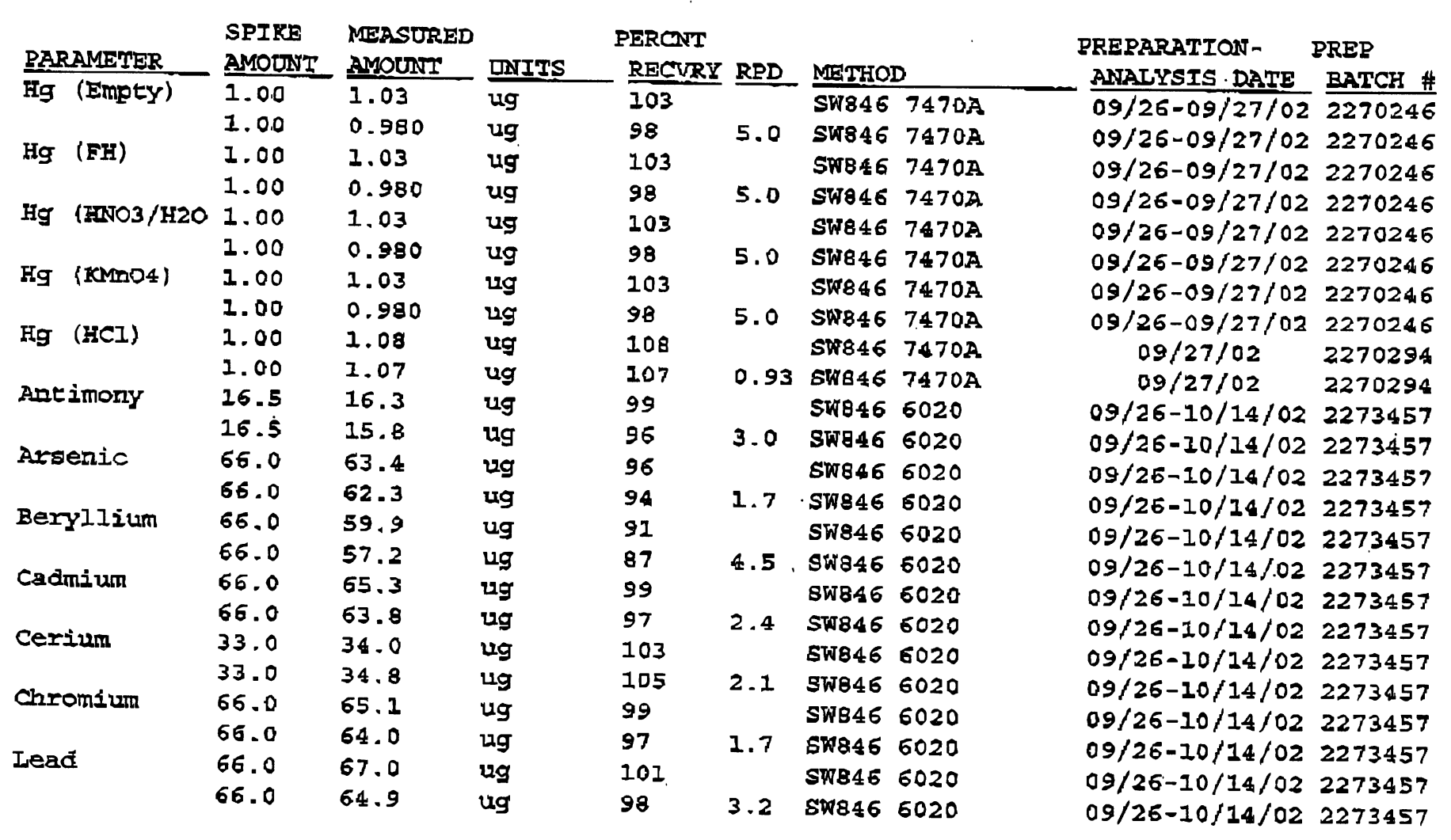

Morrs (s) : 
MATRTX SPIXB SAMPTE EVAULATION RBPORI

TOIAI Metals

Client Iot \#...: G2I250284

Date Saruled... = 09/19/02
Date Received. .: 09/25/02

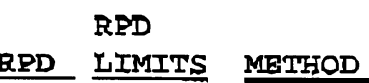

Merix.......... AIR

PREPARATION- WORK ANALYSIS DATE ORDER \#

09/26-09/27/02 E8VTH1AP

$09 / 26-09 / 27 / 02$ ESVTHIAQ

MS Iot-Sample \#: .G2I250284-001 Pxep Bacch \#... : 2270246

Hg (HNO3/H2O $99 \mathrm{G} \quad(75$ - 125) BWB46 $7470 \mathrm{~A}$

$95 \mathrm{G} \cdot(75-125) 4.4(0-20)$ SW846 $7470 \mathrm{~A}$

\section{IOTS (S) :}

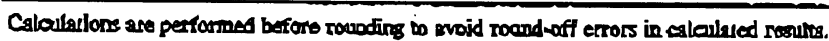

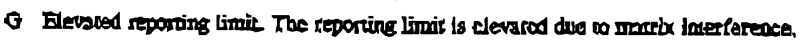




\section{MATRIX SPIRG SAMPTE DATA REPORT}

TOIAL Metals

client Iot \#...: G2I250284

Date Sampled... = 09/19/02
Date Received. : 09/25/02
Matrix......... AIR

PERCNT
RECVRY RPD METEOD
PREPARATION-
ANALYSIS DATE ORK
ORDER \#

PARAMETER AMOUDTT AMUI AMOUNT UNITS

...: 2270246

ins Iot-Sample
$\mathrm{Hg}$ (HNO3/H202)

ND $\quad 2.55 \quad 2.61$ G ug

ND $\quad 2.55$
99

95
SW846 $7470 A$

4.4 SWB46 $7470 \mathrm{~A}$
09/26-09/27/02 E8VTFLAP 09/26-09/27/02 E8VTH1AQ

\section{$\operatorname{MOTE}(S)$;}

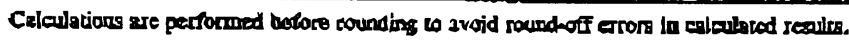

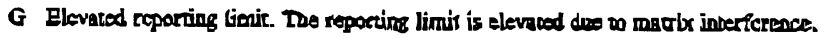




\section{SAMPLE DUPLICATE EVAUUATION REPORI}

\section{Metals}

Client Iot \#...: G2I250284

Date sampled...: 09/19/02
Work Ordex \#... : E8VIRT-SMP ESVTH-DUP

Date Received. . : 09/25/02
Matrix. ..... $\mathrm{AIR}$

\begin{tabular}{|c|c|c|c|c|c|c|c|}
\hline PARAM RESULT & $\begin{array}{l}\text { DUPLICAIE } \\
\text { RESULT }\end{array}$ & DNITS & RPD & $\begin{array}{l}\text { RPD } \\
\text { IIMIT }\end{array}$ & METHOD & $\begin{array}{l}\text { PREPARATION- } \\
\text { ANALYSIS DATE }\end{array}$ & $\begin{array}{l}\text { PREP } \\
\text { BATCH \# }\end{array}$ \\
\hline Arsenic & & & & & SD Lot-sample \#: & G2I250284-001 & \\
\hline ND & ND & ug & 0 & $(0-20)$ & SWO46 $6020^{\circ}$ & $09 / 26-10 / 14 / 02$ & 2273457 \\
\hline Berylizum & & & & & sD Lot-Bample \#: & G2I250284-001 & \\
\hline ND & ND & ug & 0 & $(0-20)$ & SW846 $6020^{\circ}$ & $09 / 26-10 / 14 / 02$ & 2273457 \\
\hline Cadmixm & & & & & SD Lot-Sample \#: & G2I2502B4-001 & \\
\hline $0.13 \mathrm{~B}$ & $0.14 \mathrm{~B}$ & ug & 3.5 & $(0-20)$ & SW846 $6020^{\circ}$ & $09 / 26-10 / 14 / 02$ & 2273457 \\
\hline Cerium & & & & & SD Lot-Sample \#: & G2I250284-00I & \\
\hline ND & ND & $\mathrm{ug}$ & 0 & $(0-20)$ & SW846 6020 & $09 / 26-10 / 14 / 02$ & 2273457 \\
\hline Chromium & & & & & SD Lot-Sample \#: & G2I250284-001 & \\
\hline ND & NDD & ug & 0 & $(0-20)$ & SW846 $6020^{\circ}$ & $09 / 26-10 / 14 / 02$ & 2273457 \\
\hline Lread & & & & & SD Lot-Sample \#: & G2I250284-001 & \\
\hline $0: 89 \mathrm{E}$ & $0.91 \mathrm{~B}$ & ug & 2.0 & $(0-20)$ & $5 \$ 8466020^{\circ}$ & $09 / 26-10 / 14 / 02$ & 2273457 \\
\hline $\begin{array}{l}\text { Antimony } \\
0.079 \mathrm{~B}\end{array}$ & $0.086 \mathrm{~B}$ & 20 & 9.4 & $(0-20)$ & $\begin{array}{l}\text { SD Lot-Sample \#: } \\
\text { SW846 } 6020\end{array}$ & $\begin{array}{l}\text { G2I250284-001 } \\
09 / 26-10 / 14 / 02\end{array}$ & 2273457 \\
\hline
\end{tabular}

NOTB (S) :

Calculations are pertormed before sounding to anoid roumd-off errors in calculnted reselts.

B Escinacod resulc. Resulr is less than Br. 


\section{APPENDEX C}

\section{ANALYTICAL DATA}

d. $\mathrm{CCl}_{4} \mathrm{AND} \mathrm{Cl}$ 
EPA T015 Results Correction

\begin{tabular}{|c|c|c|}
\hline 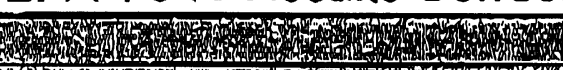 & Reported Concentration & Corrected Concentration \\
\hline (1) & (ppmvd) & $\overline{\text { (ppmvd) }}$ \\
\hline Carbon Tetrachloride & 30 & 60 \\
\hline Tetrachloride & 34 & 68 \\
\hline
\end{tabular}

\begin{tabular}{|c|c|}
\hline 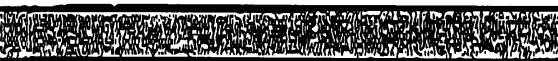 & (inches of $\mathrm{Hg}$ ) \\
\hline Barometric Pressure & 29.9 \\
\hline Summa Canister Vacuum & 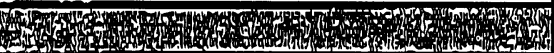 \\
\hline Initial & 15 \\
\hline Final & 0 \\
\hline
\end{tabular}

Corrected Concentration $=$ Reported Concentration * Barometric Pressure $/$ (Initial Vacuum - Final Vacuum) 


\section{@}

AIR TOXICS LTD.

AN ENVIRONMENTAL ANALYTICAL LABORATORY

\section{WORK ORDER \#: 0209522}

Work Order Summary

CIIENT:

PHONE:

FAX:

DATE RECEIVED:

DATE COMPLETED;

Mr. Gary Mata

AirKinetics, Inc.

5932 Bolea Avenue STE 105

Huntington Beach, CA 92649

714-373-0998

$714-895-1915$

9/25/02

$10 / 8 / 02$
BILL TO: Mr. Gary Mata

AirKinctics, Inc.

5932 Bolsa Avenue STE 105

Huntington Beach, CA 92649

P.o. \#

PROJECT \# 11303 General Aromics

CONTACT: Karen Burden

\begin{tabular}{ll} 
ERACTION\# & NAMEE \\
\hline $01 \mathrm{~A}$ & TO-15 \\
02A & Lab Blank \\
03A & LCS
\end{tabular}

TEST

Modified TO-15

Modified TO-15

Modified TO- 15
RECIIPT

VAC,PRESS

$0.0 \mathrm{Hg}$

NA

NA

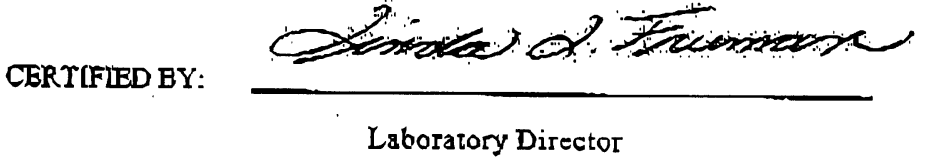

DATE: $10 / 09 / 02$

Certfication numbers: CA NELAP - 02110CA, NY NELAP - 11291, UT NELAP - 9166389892, LA NELAP/LELAP AI 30763

Name of Accrediting Agency: NELAP/Florida Deparmenc of Health, Scope of Application: Clean Air Act, Accreditation number: E87680, Effective date: 07/01/02, Expiration date: 06/30/03

Air Toxics Ltd. certifies that the test results contained in chis report meer all requirements of the NELAC standards

Thin enp ore ahall not be reproduced, oxoept in tull, without the writson epproval or dir Taxies led.

180 BLUE RAVINE ROAD. SUITE B FOLSOM, CA - 95630

(916) $985-1000,(800) 985-5955$. FAX (916) 985-1020 


\section{LABORATORY NARRATIVE \\ Modified TO-15 \\ AirKinetics, Inc. \\ Workorder\# 0209522}

One 6 Liter Summa Canister sample was received on September 25, 2002. The laboratory performed analysis via modified EPA Method TO-15 using GCMS in the full scan mode. The method involves concentrating to 0.5 liters of air. The concentrated aliquot is then flash vaporized and swept through a water management system to remove water vapor. Following dehumidification, the sample passes directly into the GCMS for analysis. See the data sheets for the reporting limits for each compound.

During the five point calibration, two low-level standards are used. The low-level standard for TO-15 compounds is spiked at $0.5 \mathrm{ppbv}$ and represents the reporting limit for these compounds. The low-level standard for the non-TO- 15 compounds is spiked at $2.0 \mathrm{ppbv}$ and represents the reporting limit for these compounds. The TO-15 compounds are present in both standards but are excluded from reporting in the 2.0 ppbv standard since a lower level is already included in the curve.

Method modifications taken to run these samples include:

\begin{tabular}{|c|c|c|}
\hline Requirement & To-15 & ATL Modifications \\
\hline Sampling/concentrator system & Nafion Drier & Multisorbent concentracor \\
\hline Blank & Hurnid Air Blank & $\begin{array}{l}\text { Humid Nitrogen Blank for standard analysis. Dry Nirrogen } \\
\text { Blank for low level analysis. }\end{array}$ \\
\hline BFB acceptance criteria & CLP protocol & SW-846 protocol \\
\hline Concentrarion of IS spike & $10 \mathrm{ppbv}$ & $25 \mathrm{ppbv}$ for TO-14;10 ppbv for low level \\
\hline Dilutions for initial calibration & $\begin{array}{l}\text { Dynamic dilutions or } \\
\text { static using canisters }\end{array}$ & Syringe dilutions \\
\hline ICAI \%RSD acceptance criteria & $\begin{array}{l}30 \% \text { or less, } 40 \% \text { or } \\
\text { less for up to two } \\
\text { compounds }\end{array}$ & $\begin{array}{l}30 \% \text { or less for standard compounds, } 40 \% \text { or less for } \\
\text { non-standard and polar compounds or }=30 \% \text { pooled RSD } \\
\text { of all compounds }\end{array}$ \\
\hline IS recoveries & $\begin{array}{l}\text { Within } 40 \% \text { of mean } \\
\text { over ICAL for blanks, } \\
\text { and w/in } 40 \% \text { of daily } \\
\text { CCV for samples. }\end{array}$ & Within $40 \%$ of CCV recoveries for blank and samples. \\
\hline IS RTs & $\begin{array}{l} \pm 0.33 \mathrm{~min} \text { from most } \\
\text { recent calibration } \\
\text { (either ICAL or daily) }\end{array}$ & $\pm 0.33 \mathrm{~min}$ of RT in daily CCV \\
\hline Daily CCV & $70-130 \%$ & $\begin{array}{l}\text { Standard compounds: } 70-130 \% \text { for at least } \\
90 \% ; \text { Non-scandard and polar compounds: } 60-140 \% \text { for at } \\
\text { least } 80 \%\end{array}$ \\
\hline RF for quantitation & From daily CCV & From ICAL \\
\hline MSD scan range & $35-300$ arma & $35-350 \mathrm{amu}$ \\
\hline
\end{tabular}

\section{Receiving Notes}

There were no receiving discrepancies.

\section{Analytical Notes}

There were no analytical discrepancies. 


\section{Definition of Data Oualifying Flags}

Seven qualifiers may have been used on the data analysis sheets and indicates as follows:

B - Compound present in laboratory blank greater than reporting limit (background subtraction nol performed).

$\checkmark$ - Estimated value.

E - Exceeds instrument calibration range.

S - Saturated Peak.

$Q$ - Exceeds quality control limits.

U - Compound analyzed for but not detected above the reporting limit

$\mathrm{N}$ - The identification is based on presumptive evidence.

File extensions may have been used on the data analysis sheets and indicates as follows:

a-File was requantified

b-File was quantified by a second column and detector

rl-File was requantified for the purpose of reissue 


\section{AIR TOXICS LTD.}

\section{SAMPLE NAME: TO-15}

IDH: 0209522-01A

MODIFIED EPA METHOD TO-15 GCMS FULL SCAN

\begin{tabular}{|c|c|c|c|c|}
\hline Compound & $\begin{array}{c}\text { Rot. Limit } \\
\text { (ppbv) }\end{array}$ & $\begin{array}{l}\text { Rpt. Limit } \\
\text { (uG/m3) }\end{array}$ & $\begin{array}{c}\text { Amount } \\
\text { (ppbv) }\end{array}$ & $\begin{array}{l}\text { Amount } \\
\text { (uG/m3) }\end{array}$ \\
\hline Carbon Tetrachloride & 1.3 & 8.6 & 30 & 190 \\
\hline Tetrachloroethene & 1.3 & 9.2 & 34 & 240 \\
\hline \multicolumn{5}{|c|}{ Contalner Type: 6 Liter Summa Canister } \\
\hline Surrogates & & \%Recovery & & $\begin{array}{c}\text { Method } \\
\text { Limits }\end{array}$ \\
\hline 1,2-Dichloroethane-d4 & & 93 & & $70-130$ \\
\hline Toluene-d8 & & 89 & & $70-130$ \\
\hline 4-Bramafluarobenzene & & 82 & & $70-130$ \\
\hline
\end{tabular}




\section{AIR TOXICS LTD.}

\section{SAMPLE NAME: Lab Blank}

ID\#: 0209522-02A

MODIFLDD EPA METHOD TO-15 GCMS FULL SCAN

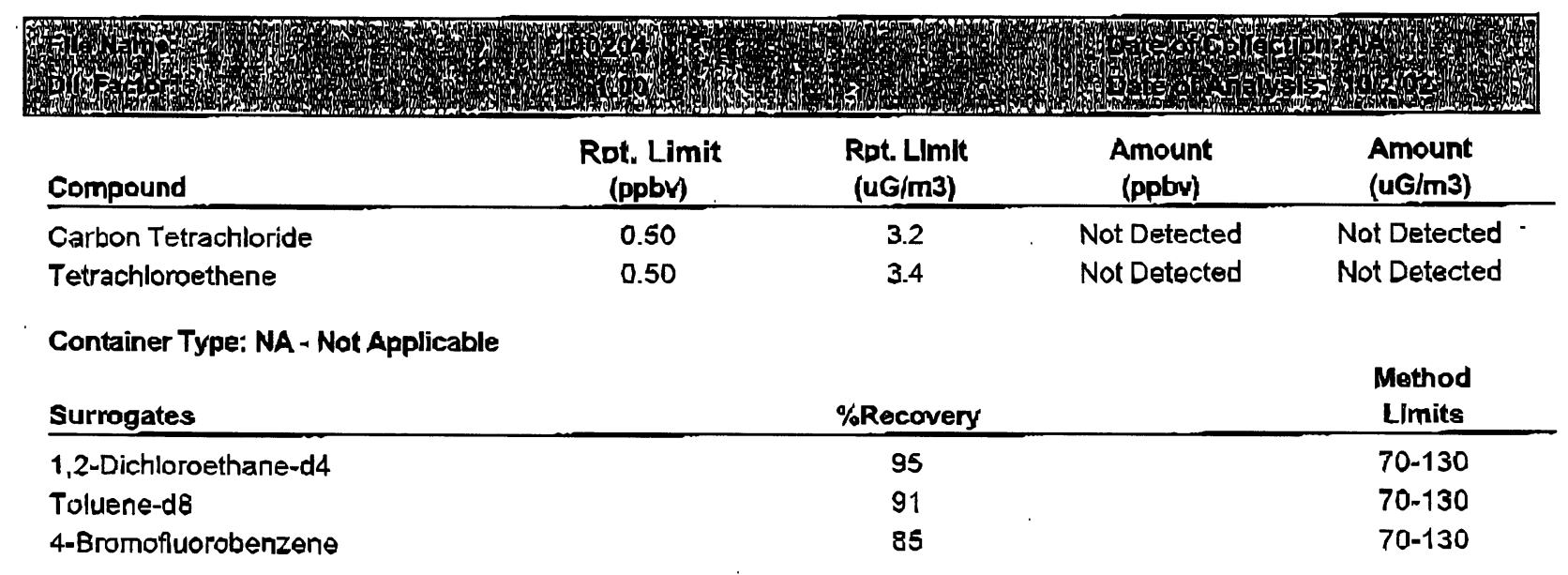




\section{AIR TOXICS LTD.}

\section{SAMPLE NAME: LCS}

ID\#: 0209522-03A

MODIFIED EPA METHOD TO-15 GCMS FULL SCAN

\begin{tabular}{|c|c|c|c|}
\hline \multicolumn{4}{|c|}{ 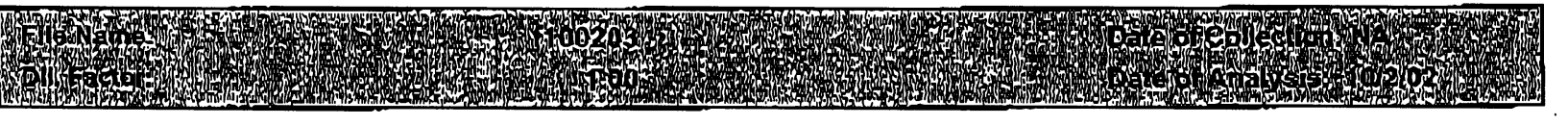 } \\
\hline Compound & $\begin{array}{l}\text { Rot. Limit } \\
\text { (ppbv) }\end{array}$ & $\begin{array}{l}\text { Rpt. Limit } \\
\text { (UG/m3) }\end{array}$ & YRecovery \\
\hline Carbon Tetrachloride & 0.50 & 3.2 & 117 \\
\hline Tetrachloroethene & 0.50 & 3.4 & 110 \\
\hline \multicolumn{4}{|c|}{ Container Type: NA - Not Applicable } \\
\hline Surrogates & & \%Recovery & $\begin{array}{l}\text { Method } \\
\text { Limits }\end{array}$ \\
\hline 1,2-Dichlorosthane-d4 & & 105 & $70-130$ \\
\hline Toluene-d8 & & 90 & $70-130$ \\
\hline 4-Bramofluorobenzene & & 83 & $70-130$ \\
\hline
\end{tabular}




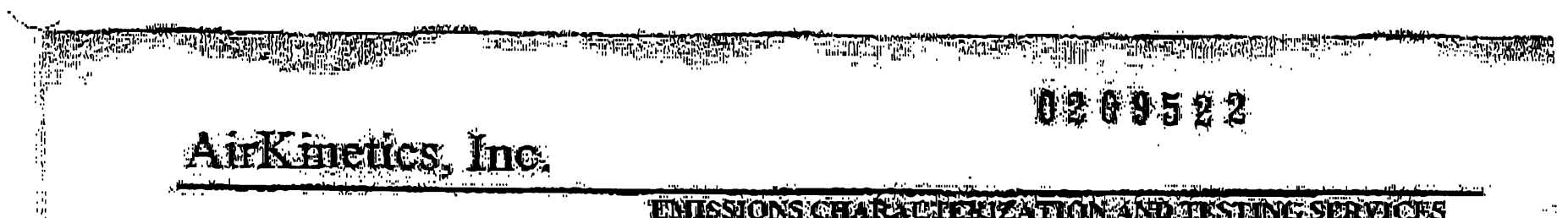

\section{Airat anetics lno:}

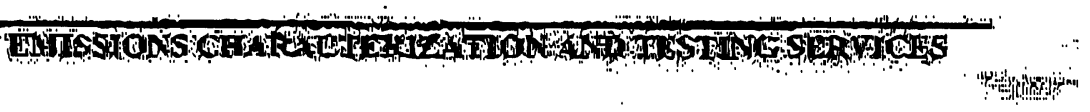

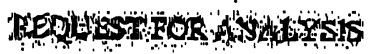

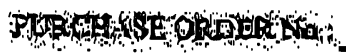
180.

Jols (a)

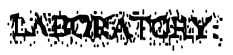

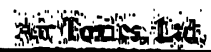

2010: 10

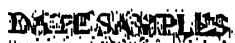

Whot

9250

6xomegrom

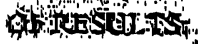
Lar

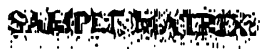
Sinckising

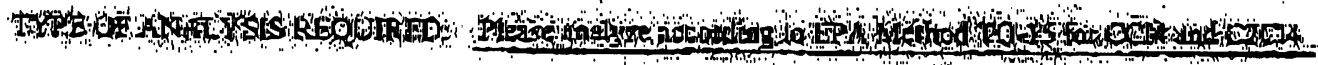

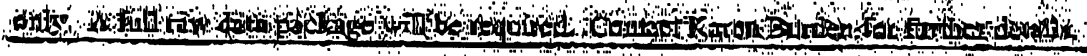

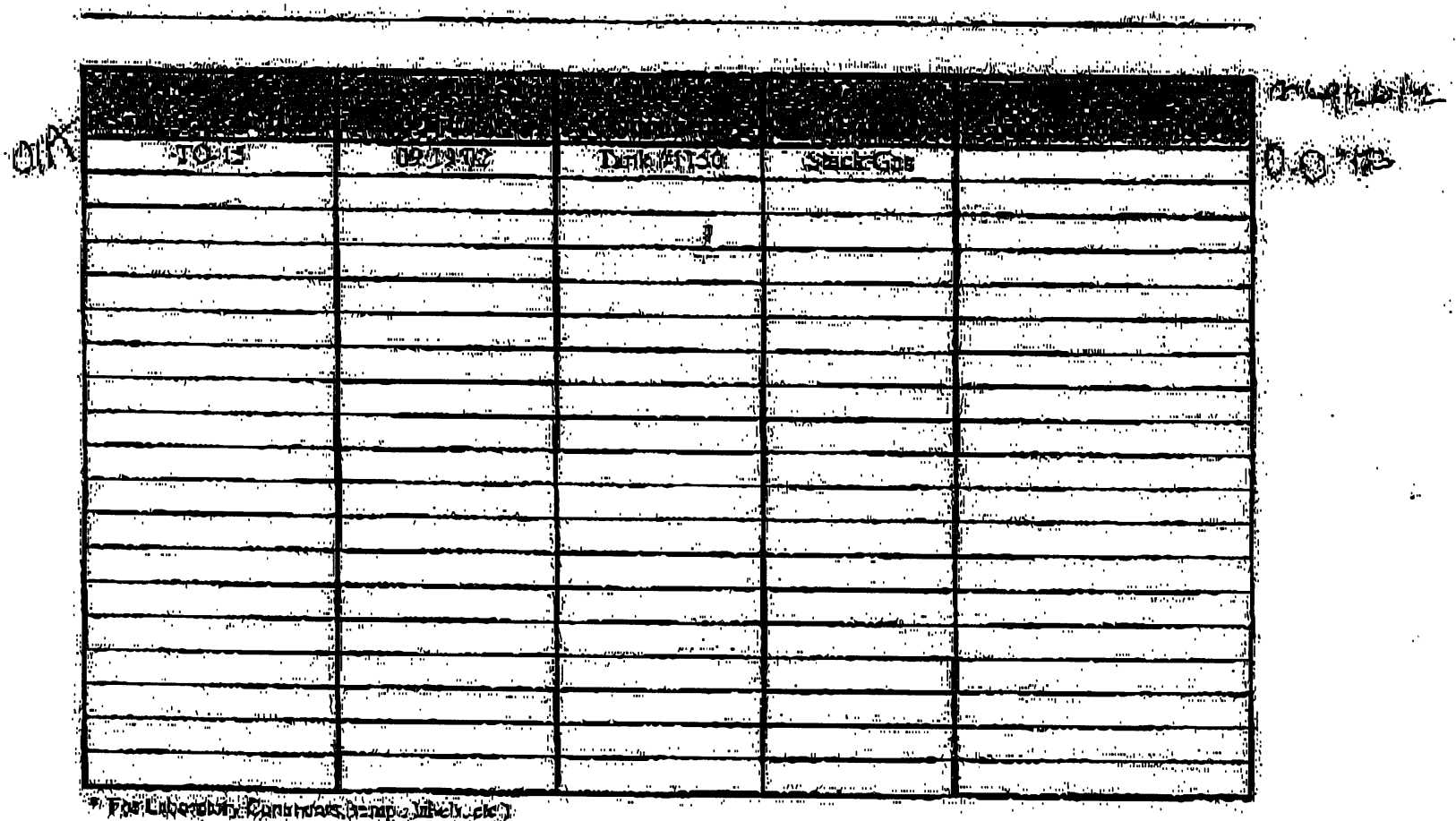

5 Sind

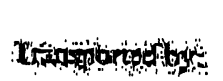

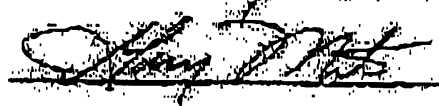

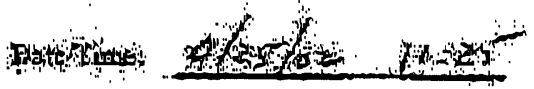

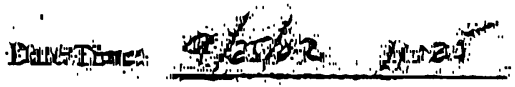

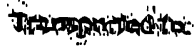

Niving

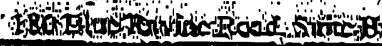

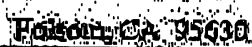

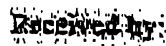

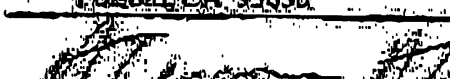

